\title{
A MULTISCALAR APPROACH TO MODELING THE END OF THE NEOLITHIC ON THE GREAT HUNGARIAN PLAIN USING CALIBRATED RADIOCARBON DATES
}

\author{
Richard W Yerkes ${ }^{1}$ Attila Gyucha ${ }^{2} \cdot$ William Parkinson ${ }^{3}$ \\ ABSTRACT. This article presents the results of a multiscalar analysis of 168 radiocarbon dates from Neolithic and Copper \\ Age sites on the Great Hungarian Plain. We examined chronological patterns at different geographic scales to explore socio- \\ economic changes that occurred during the transition from the Neolithic to the Copper Age. The beginning and end of the Late \\ Neolithic (5000-4500 cal BC) and Early Copper Age (4500-4000 cal BC) were modeled with ${ }^{14} \mathrm{C}$ dates calibrated with the \\ CALIB 5.01 program and IntCal04 calibration curve. Our attempts to identify chronological subphases within these 500-yr- \\ long periods were confounded by multiple intercepts in the calibration curve. The analysis indicated that terminal Late \\ Neolithic (4700-4300 cal BC) and "transitional" Proto-Tiszapolgár occupations (4600-4250 cal BC) at tell sites were con- \\ temporary with initial Early Copper Age habitations (4450-4250 cal BC). Calibrated dates from small Early Copper Age set- \\ tlements at Vésztố-Bikeri and Körösladány-Bikeri document changes in community and household organization that took \\ place over several decades during the transition to the Copper Age. Bayesian analysis indicated that the small fortified sites \\ were occupied contiguously in phases of 30-50 yr. The younger Körösladány-Bikeri site was established before the older \\ Vésztó-Bikeri site was abandoned. When large nucleated Late Neolithic communities dispersed and established small Early \\ Copper Age settlements, the pattern of vertical accretion that had created the Late Neolithic tells gave way to a pattern of hor- \\ izontal settlement accretion at the smaller settlements.
}

\section{INTRODUCTION: THE RADIOCARBON REVOLUTION CONTINUES}

The "Radiocarbon Revolution" had a tremendous impact on our understanding of major events that affected the course of human social evolution across the globe, but especially within Europe (Renfrew 1973). New ${ }^{14} \mathrm{C}$ dating techniques forced prehistorians to reconsider the temporal and spatial relationships between different archaeological "cultures" and the timing and sequence of different events and processes. Our understanding of the beginning of agriculture in Europe was shaped by the analysis (and reanalysis) of calibrated ${ }^{14} \mathrm{C}$ dates that indicated a spread of farming from the southeast to the northwest between 8000 and 4000 cal BC (Ammerman and Cavalli-Sforza 1973; Thorpe 1996; Whittle 1996; Price 2000; Ammerman and Biagi 2003; Gkiasta et al. 2003; Robb and Miracle 2007). More recently, the development of accelerator mass spectrometry (AMS) techniques and innovative statistical methods, combined with the widespread availability of ${ }^{14} \mathrm{C}$ dating and the constant refinement of calibration curves, has allowed us to fine-tune the temporal and geographic contexts of the social relationships that existed between different cultural complexes.

The initial impact of the ${ }^{14} \mathrm{C}$ revolution was a major reworking of macroscale chronological frameworks spanning several millennia (with periods that were several centuries long) and regional cultural sequences covering hundreds of thousands of $\mathrm{km}^{2}$ in southeast Europe. For example, Figure 1 depicts how calibrated ${ }^{14} \mathrm{C}$ dates shifted the Hungarian Copper Age from the 2nd and 3rd millennia $\mathrm{BC}$ back to the 4 th and 5th millennia. Calibrated ${ }^{14} \mathrm{C}$ dates had a similar effect on the conventional Neolithic chronologies.

Our synthesis of 168 calibrated ${ }^{14} \mathrm{C}$ dates from Late Neolithic and Copper Age contexts on the Great Hungarian Plain demonstrates that these macroregional chronological periods (i.e. "Late Neolithic" and "Early Copper Age") are associated with several changes in material culture that are indicative

\footnotetext{
${ }^{1}$ Department of Anthropology, Ohio State University, 4034 Smith Laboratory, 174 W. 18th Avenue, Columbus, Ohio 432101106, USA. Corresponding author. Email: yerkes.1@osu.edu.

${ }^{2}$ Field Service for Cultural Heritage (KÖSZ), Hungary.

${ }^{3}$ Department of Anthropology, Field Museum of Natural History, Chicago, Illinois 60605, USA.
} 


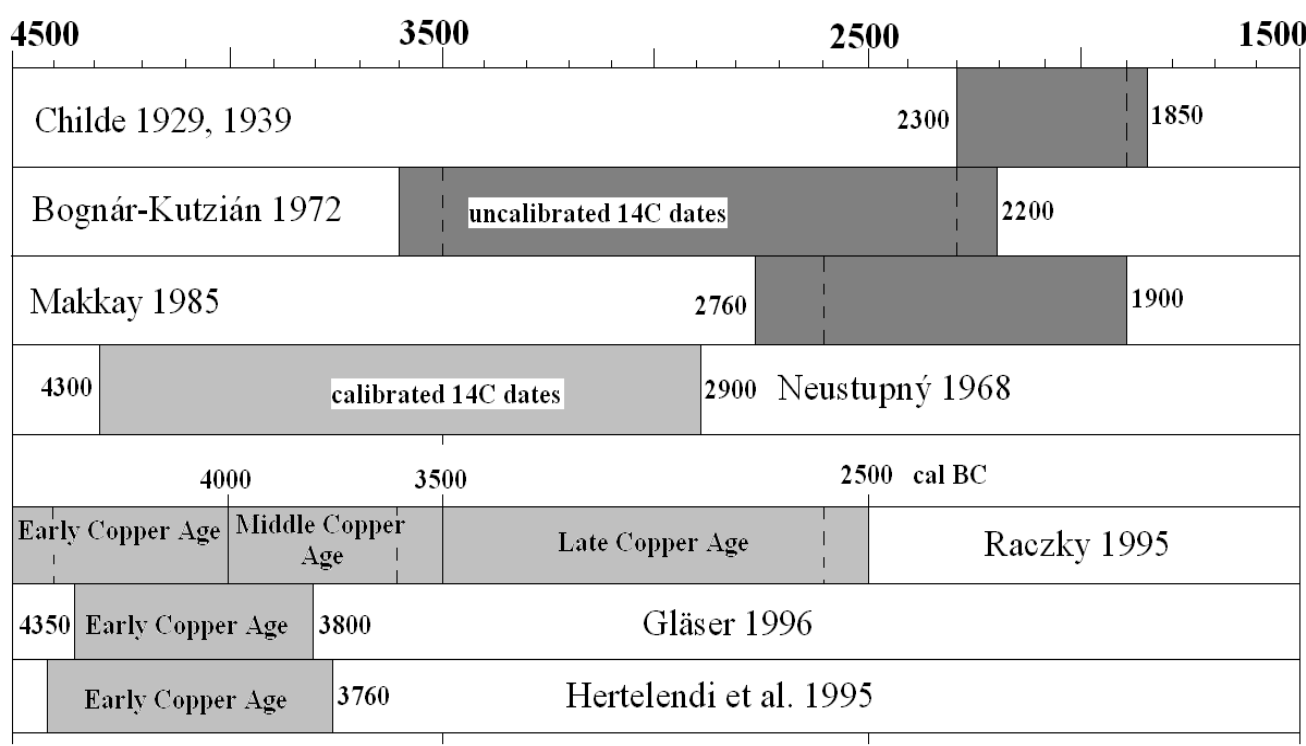

Figure 1 An example of how the "Radiocarbon Revolution" moved the Hungarian Copper Age from the 2nd and 3rd millennia BC back to the 4th and 5th millennia. The top 3 timeframes (dark shading) are based on correlations with historic records, stratigraphic sequences (e.g. the Tărtăria tablets, the sequence at Troy), and uncalibrated ${ }^{14} \mathrm{C}$ dates. The lower 4 chronologies (light shading) are based on calibrated ${ }^{14} \mathrm{C}$ dates. Calibrating ${ }^{14} \mathrm{C}$ dates had a similar effect on the Neolithic chronology. The most recent chronological frameworks, based on summed probabilities of calibrated ${ }^{14} \mathrm{C}$ dates at $1 \sigma$, estimate the span of the Early Copper Age as 4500/4400-4000 cal BC (Raczky 1995), 4350-3800 cal BC (Gläser 1996), or 4410-3760 cal BC (Hertelendi et al. 1995).

of social changes that occurred throughout the eastern Carpathian Basin during the early 5th millennium BC. But more detailed analyses of these macroregional patterns at the regional and microregional (local) scales reveal more subtle processes that lasted decades (not centuries) and involved local groups of agriculturalists that lived in river drainage systems covering hundreds (not tens of thousands) of $\mathrm{km}^{2}$ within the Great Hungarian Plain. By examining patterns at these different geographic and temporal scales, both long- and short-term patterns in settlement organization and landscape use can be documented. This, in turn, helps us better understand-in very explicit termshow the transition from the Neolithic to the Copper Age actually took place.

\section{A MULTISCALAR APPROACH TO THE NEOLITHIC-COPPER AGE TRANSITION}

Our methodology in exploring the various changes that occurred at the end of the Neolithic builds upon other successful studies that integrate multiple scales of analysis (e.g. Neitzel 1999; Fowles 2002; Knapp 2002; Parkinson 2006a,b). We concentrate on 3 geographic and social scales: 1) the macroregional scale, which corresponds to the entirety of the Great Hungarian Plain, or Nagy Alföld, an area of approximately $52,000 \mathrm{~km}^{2}$ in the eastern Carpathian Basin; 2) the regional scale, which corresponds to the eastern portion of the Körös-Berettyó river system in Békés County, Hungary, an area of $\sim 2500 \mathrm{~km}^{2}$ on the southeastern part of the Great Hungarian Plain; and 3) the microregional scale, which corresponds to 3 sites located on 1 branch of this river system, the Holt Sebes Körös near the modern town of Vésztô.

We also differentiate long-term temporal patterns on the order of several centuries or millennia from shorter patterns that span several generations. We assume that the ancient cultural processes in 
which we are interested were working simultaneously at the different geographic and temporal scales. Nevertheless, we have found it helpful to adopt an approach that examines related processes at different temporal and geographic scales because the information gained from examining 1 scale can be used to help interpret patterning at the other scales.

The macroregion we discuss includes the entirety of the Great Hungarian Plain in the eastern Carpathian Basin, a homogeneous, geographically discrete region encompassed by the floodplain of the Tisza River on the north, the sandy interfluve between the Danube and the Tisza rivers on the west, the floodplain of the Máros River on the south, and the Transylvanian foothills of the Carpathian Mountains on the east.

Our regional study area is the eastern portion of the Körös-Berettyó river system within the Great Hungarian Plain. This alluvial basin is almost perfectly flat, with elevations $83-102 \mathrm{~m}$ asl. Prior to the 19th century, a very complex river system with permanent and seasonal rivers and streams flowed through the region. The 3 branches of the Körös River, and the Berettyó River, still flow west from the Carpathian Mountains and merge before draining into the Tisza, which flows south to join the Danube (Figure 2). The Körös River system was the main west-east corridor throughout prehistory that linked the Great Hungarian Plain with the metal and lithic resources of Transylvania. Large marshlands fed by intermittent floods from the Berettyó and the Körös rivers also covered much of the Körös flatlands, inundating lower areas for weeks or even months.

Our microregional analysis focuses on 3 settlements located near the modern town of Vésztó along the Holt Sebes Körös River. These include the multicomponent tell site of Vésztó-Mágor, as well as the sites of Vésztó-Bikeri and Körösladány-Bikeri, 2 smaller fortified villages that have substantial Early Copper Age occupation layers (Figure 3).

Archaeological sites dating from the Early Neolithic to the end of the Middle Ages tend to be found almost exclusively at higher elevations in the Körös region, on low ridges stretching along the riverbanks and on the "islands" in the flooded marshlands. Late Neolithic farming groups established a complex settlement system centered on tells, which were inhabited for several centuries, and "flat" settlements, which were occupied for shorter intervals (Makkay 1982; Kalicz and Raczky 1987a; Raczky and Anders 2008). Late Neolithic material culture assemblages are characterized by increasing regionalization, which is exhibited in ceramic assemblage variability, trade networks, settlement organization, settlement patterns, and subsistence practices (Parkinson 2006a). Following the initial phase of the Late Neolithic (Tisza I/II, see Raczky 1992; Lichardus and Lichardus-Itten 1996; Horváth 2000), this regionalization resulted in the emergence of discrete archaeological "cultures" known as the Tisza-Herpály-Csôszhalom complex, roughly contemporary with Lengyel I-II cultures in Transdanubia and northern Hungary, the Iclod group and the Petreşti culture in Transylvania, and the Vinča B2-D2 phases in the northern Balkans (Bánffy 2007; Gläser 1996; Hertelendi et al. 1998a; Kalicz and Raczky 1987a:25-27; Raczky 1988, in press; Raczky and Anders 2008). Several scholars have identified a transitional period from the Late Neolithic to the Copper Age known as the Proto-Tiszapolgár phase (see Appendices 1 and 2). Artifacts associated with this phase have been recovered at sites across the Great Hungarian Plain (and beyond) and in the uppermost levels of several Late Neolithic tells (Lichardus and Vladár 1964; Šiška 1968; Horváth 1985, 2005; Kalicz and Raczky 1987a,b), but the phase remains poorly defined (Parkinson 2006a:50-1).

Many systematic excavations have been carried out on Late Neolithic tells and flat sites over the last $30 \mathrm{yr}$, but the succeeding Early Copper Age has received considerably less attention. The beginning of the Copper Age is marked by a gradual homogenization in ceramic style in the territory of the Tisza-Herpály-Csőszhalom complex as most tells and large flat settlements were abandoned. The 


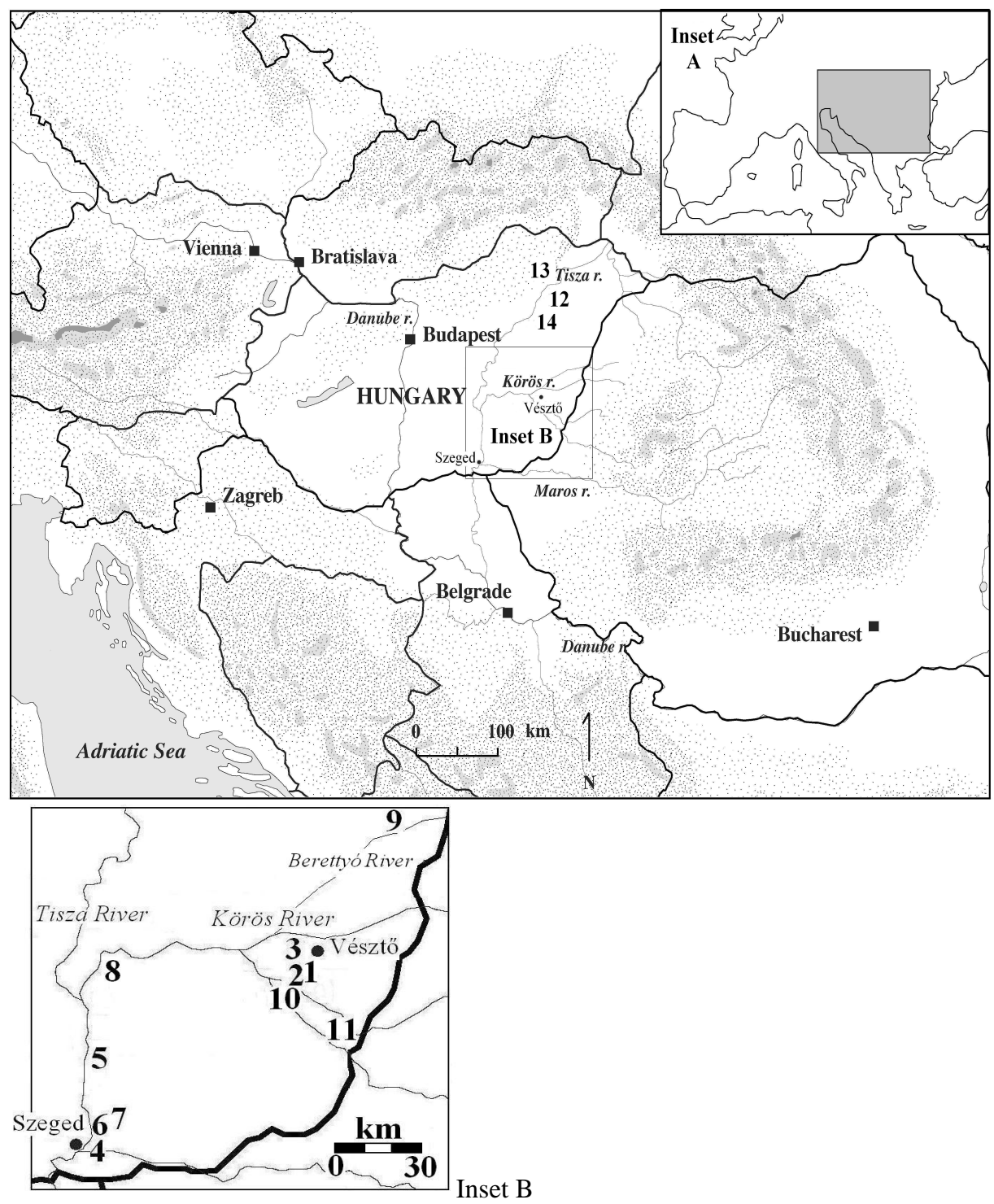

Figure 2 Map of the Great Hungarian Plain in the Carpathian Basin in southeast Europe (macroregion, see Inset A). The eastern part of the Körös-Berettyó river system is shown in Inset B. The Holt Sebes Körös River microregion is just west of the town of Vésztő, Hungary. Locations of sites discussed in this study (on Inset B): 1.Vésztô-Bikeri; 2. Körösladány-Bikeri; 3. Vésztő-Mágor; 4. Tápé-Lebő-A; 5. Szegvár-Túzköves; 6. Hódmezővásárhely-Kökénydomb; 7. Hódmezővásárhely-Gorzsa; 8. Öcsöd-Kováshalom; 9. Berettyóújfalu-Herpály; 10. Bélmegyer-Mondoki domb; 11. Méhkerék 23; (on large map): 12. Polgár-Csőszhalom; 13. Tiszalúc-Sarkad; 14. Tiszapolgár-Basatanya.

Early Copper Age Tiszapolgár culture extended from the Banat in northern Serbia and southwestern Romania, across the entire Hungarian Plain, into the foothills of Transylvania and the mountains of eastern Slovakia (Bognár-Kutzián 1972). Although there were many cultural links between Late Neolithic and Early Copper Age groups, the end of the Neolithic also was marked by dramatic changes in social organization, technology, economy, house form, site layout, settlement distribution, and mortuary customs (Parkinson 2002:391-4). Similar changes occurred at this time across 


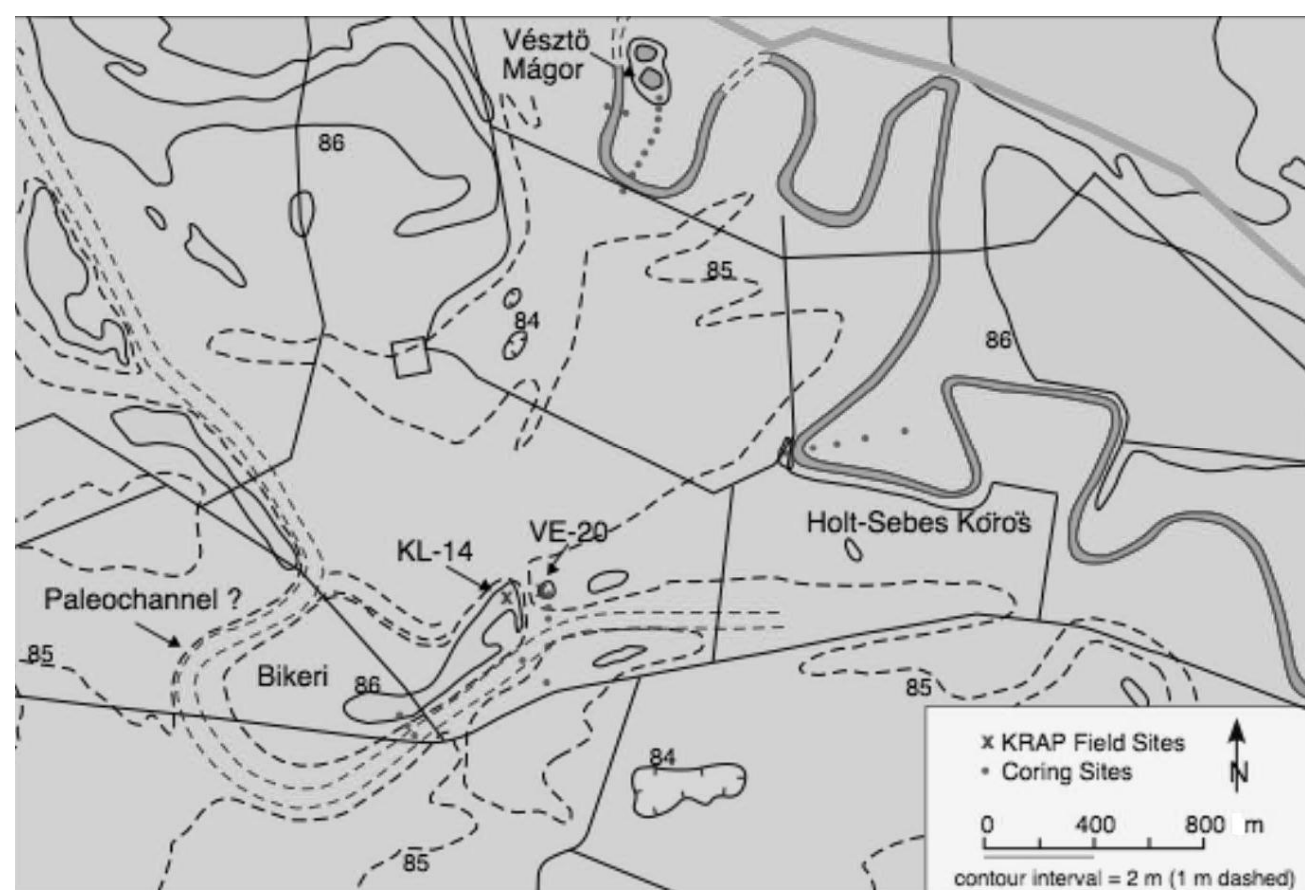

Figure 3 Locations of the Early Copper Age Vésztô-Bikeri (VE-20) and Körösladány-Bikeri (KL-14) sites and the Vésztó-Mágor tell in the Holt Sebes Körös River microregion (after Frolking 2004).

much of southeast Europe as populations dispersed to smaller sites and abandoned larger villages and tells (Demoule and Perlès 1993). On the Great Hungarian Plain, this transition affected many aspects of social organization-from households and villages to regional settlement systems. In contrast to previous researchers, who attributed the changes at the end of the Neolithic to the emigration of Indo-European speakers into the region (Childe 1939; Gimbutas 1997), most scholars now associate these changes with indigenous social processes (Bognár-Kutzián 1963, 1972; Bökönyi 1974, 1986; Makkay 1982; Kaiser and Voytek 1983; Siklódi 1983; Kalicz 1988; Bánffy 1994; Raczky 1995; Horváth 2005; Parkinson 2006a,b).

\section{RADIOCARBON DATES AND CHRONOLOGY IN THE CARPATHIAN BASIN}

An absolute chronology based on ${ }^{14} \mathrm{C}$ age determinations was not immediately accepted in southeast Europe, where most scholars were committed to typochronological approaches based primarily on ceramic seriations. During the 1960s and 1970s, Hungarian archaeologists used ${ }^{14} \mathrm{C}$ dates to help refine these conventional Neolithic and Copper Age typochronologies (Bognár-Kutzián 1963, 1972; Kalicz 1970). When the first ${ }^{14} \mathrm{C}$ samples were run by labs in Berlin and Groningen (Kohl and Quitta 1964, 1966; Vogel and Waterbolk 1963), the differences between the uncalibrated ${ }^{14} \mathrm{C}$ dates and the traditional absolute chronologies were so significant that some rejected all ${ }^{14} \mathrm{C}$ dates as inaccurate and unreliable (Hertelendi et al. 1995:239). Some scholars still contend that ${ }^{14} \mathrm{C}$ samples are only useful for dating much more recent events (e.g. Makkay 2007:217-30). Despite some resistance, when Hungarian dates (and other ${ }^{14} \mathrm{C}$ dates from Europe) were calibrated and analyzed by Neustupný $(1968,1970)$ and Renfrew $(1970,1973)$ it became clear that the traditional typochronologies were woefully inaccurate. The calibrated dates suggested that Neolithic and Copper Age cultures on the Great Hungarian Plain did not form neat, short, chronological sequences, but overlapped considerably (Hertelendi et al. 1995). 
In the mid-1990s, 268 calibrated ${ }^{14} \mathrm{C}$ dates from Early Neolithic $(n=28)$, Middle Neolithic $(n=47)$, Late Neolithic $(n=185)$, and Copper Age $(n=8)$ contexts were used to refine conventional chronologies and to establish absolute temporal sequences for 4 stratified Late Neolithic tells on the Plain (Hertelendi and Horváth 1992; Hertelendi et al. 1995, 1998a,b; Horváth and Hertelendi 1994). Hertelendi and his colleagues used the CALIB 3.0.3 calibration program (Stuiver and Reimer 1993) on each group of dates and calculated the cumulative probability distributions at $1-\sigma(68.3 \%)$ confidence intervals to estimate the timespan for each period and for Neolithic and Copper Age levels within tell sequences. This data set formed the basic absolute chronology for the region, and has been essential for refining models of social organization and interaction, especially during the Late Neolithic (e.g. Kalicz and Raczky 1987a; Raczky and Anders 2008; Raczky, in press). But the lack of absolute dates from systematically excavated Early Copper Age settlement contexts impeded our understanding of the various social changes that occurred at the end of the Neolithic, when most of the tells on the Great Hungarian Plain were abandoned.

For this study, we synthesized 168 conventional ${ }^{14} \mathrm{C}$ dates from Late Neolithic (64\%), Early Copper Age (28\%), and Middle Copper Age (8\%) contexts. We added 32 new ${ }^{14} \mathrm{C}$ samples from 2 Early Copper Age settlements in the Vésztô microregion ${ }^{4}$ to the database that had been compiled by Ede Hertelendi and his colleagues ${ }^{5}$ (Appendix 1). Using the CALIB 5.01 program (Stuiver and Reimer 1993) and the IntCal04 calibration curve (Reimer et al. 2004; Blackwell et al. 2006), we calibrated the new Copper Age dates and recalibrated conventional dates that had been analyzed using the IntCal98 curve (Appendix 2). We also employed Bayesian statistical methods of analysis that are included in the BCal (Buck et al. 1999) and OxCal 4 (Bronk Ramsey 1995, 2001) ${ }^{6}$ programs to obtain higher resolution for dates and phases. The main advantage of the Bayesian approach is that it permits us to test the reliability of temporal frameworks independently of typochronologies, thus providing a more objective basis for comparing individual sequences from different sites (see Buck 1999, 2001).

Bayesian analysis is based on Bayes' theorem, which has 3 related components (where = means "is proportional to"):

$$
\text { posterior }=\text { likelihood } \times \text { prior }
$$

The likelihood is a statement about the probability of obtaining specific data values given specific information about some parameters of the explanatory model. It can be denoted as $P(y \mid \theta)$, where $P$ is probability and $y$ is data that has been collected and $\theta$ are parameters of the model, and $\mid$ is read as "given." It is a formal statement of the relationship between what is to be learned and the data that is collected. The prior, $P(\theta)$, is a formal statement of what was known before the latest data were collected. The posterior is what is to be learned, $P(\theta \mid y)$, a combination of the information contained in the data, the model, and the prior. It is the probability attached to specified values of the unknown parameters of the model given all of the observations. The posterior can be obtained by multiplying the likelihood by the prior and then normalizing the results so that the probabilities add up to 1

\footnotetext{
${ }^{4}$ See Gyucha et al. 2004, 2006; Parkinson et al. 2002, 2004a,b; Sarris et al. 2004; Yerkes et al. 2007 for details on investigations by the Körös Regional Archaeological Project (KRAP).

${ }^{5}$ We obtained a list of these dates from Éva Svingor of the Institute of Nuclear Research of the Hungarian Academy of Sciences at Debrecen. See Bognár-Kutzián 1985; Bognár-Kutzián and Csongor 1987; Hertelendi and Horváth 1992; Hertelendi et al. 1995, 1998a,b; Horváth and Hertelendi 1994; Kalicz 1985; Kalicz and Raczky 1987a for previously published dates on this list and summaries of their analyses.

${ }^{6}$ Webpages: http://bcal.sheffield.ac.uk and http://c14.arch.ox.ac.uk/embed.php?File=oxcal.html; also see Buck 1999, 2001 and other references on the webpages for details about the methods of Bayesian analyses.
} 
(Zeidler et al. 1998:168-9; Buck 1999, 2001). The problem with calculating probabilities of this form is that they are multidimensional. For this reason, Markov chain Monte Carlo is used to obtain a representative sample of possible solutions for the posterior (Bronk Ramsey 1995, 2001).

We separated the dates in our data sets using stratigraphic information from excavations at the tells and flat sites (see Appendices 1 and 2), but did not assign any a priori dates to the beginning and ending of the cultural periods or phases. We tried to use groups of related dates to refine time ranges for occupation layers within tells and for occupation episodes at flat sites using these techniques, but our efforts were confounded by multiple intercepts in the calibration curve during the 5th millennium BC (Blackwell et al. 2006:411).

\section{MACROREGIONAL AND LONG-TERM PATTERNS: DATING THE END OF THE NEOLITHIC PERIOD ACROSS THE GREAT HUNGARIAN PLAIN}

Our recalibration of the 136 published ${ }^{14} \mathrm{C}$ dates from several Late Neolithic and Copper Age sites using the CALIB 5.01 program and the IntCal04 calibration curve (Figure 4) reinforces the absolute chronology established by Hertelendi and his colleagues in the 1990s. The summed probabilities for 107 Late Neolithic dates range from 5021-4402 cal BC ( $1 \sigma$, Figure 4). When 4 Proto-Tiszapolgár phase dates are excluded, the summed probabilities for the remaining 103 Late Neolithic dates are nearly identical (5025-4450 cal BC). These results support the currently accepted timespan for the Late Neolithic on the Great Hungarian Plain: about 5000-4500 cal BC (Raczky 1988, 1992, in press; Parkinson 2006a). The summed probabilities for 39 dates from 4 early Tisza phase sites range between 5216 and $4856 \mathrm{cal} \mathrm{BC}^{7}$ This $360-\mathrm{yr}$ interval is very close to the 400-yr span (5120-4710 cal BC, $1 \sigma$ ) that Hertelendi et al. (1995:242) established for the early Tisza transitional formation using the CALIB 3.03 program. The oldest dates from the early Tisza levels at these sites overlap with the Middle Neolithic period (5330-4940 cal BC) and are contemporary with calibrated dates from other Linear Pottery (AVK) sites elsewhere on the Great Hungarian Plain (Raczky, in press). Summed probabilities $(1 \sigma)$ for 29 dates from 3 Tisza sites are 4893-4497 cal BC. The results for 8 dates from Csôszhalom contexts at 3 Late Neolithic sites are 4942-4374 cal BC, while the summed probabilities for 27 samples from 3 Herpály sites, including 3 Proto-Tiszapolgár phase dates, are $4717-4455$ cal BC. When the 3 Proto-Tiszapolgár phase dates are excluded, the range for the Herpály sites is reduced to $4721-4452 \mathrm{cal} \mathrm{BC}$.

Most of the dates for Late Neolithic contexts in our sample came from a few multicomponent tell sites. ${ }^{8}$ The summed probabilities of the dates from these sites suggest that they were occupied for 300-350 yr, or about 10 generations (Figure 5). This is close to the 285-yr average that Hertelendi et al. (1998b:664) calculated for the Öcsöd-Kováshalom, Polgár-Csőszhalom, HódmezôvásárhelyGorzsa, and Berettyóújfalu-Herpály tells. Unfortunately, the multiple intercepts and plateaus on the calibration curve, the margin of error of the ${ }^{14} \mathrm{C}$ measurements, and the possibility of mixed depositional contexts make it difficult to reduce the date ranges from the individual tell levels to generations rather than centuries (see Appendix 2). For example, Hertelendi et al. (1998a,b) estimated that the timespan for 3 stratigraphic levels (Levels 1-3) at Polgár-Csốszhalom ranged from 151-265 yr for each level, while the span of the entire tell sequence was 280 yr. At Berettyóúffalu-Herpály,

${ }^{7}$ These samples included 17 dates from Tápé-Lebő-A (5300-4729 cal BC), 10 dates from Hódmezővásárhely-Kökénydomb (5205-4617 cal BC), 8 dates from Szegvár-Túzköves (5214-4618 cal BC), and 4 dates from levels 3 and 4 at Vésztó-Mágor (5222-4798 cal BC).

${ }^{8}$ For the Tisza culture, 26 of the 29 dates (90\%) came from Hódmezôvásárhely-Gorzsa tell, 6 of the 8 dates (75\%) for the Csốszhalom culture came from Polgár-Csôszhalom, and 25 of the 27 dates (93\%) from the Herpály culture sites came from Berettyóújfalu-Herpály. 
Hertelendi and his colleagues found that the time ranges for tell levels 5 through 9 varied from 215$376 \mathrm{yr}$, while the average for the entire Late Neolithic sequence at the tell was $280 \mathrm{yr}$. We had hoped that the new calibration curve would help resolve these discrepancies, but it did not.

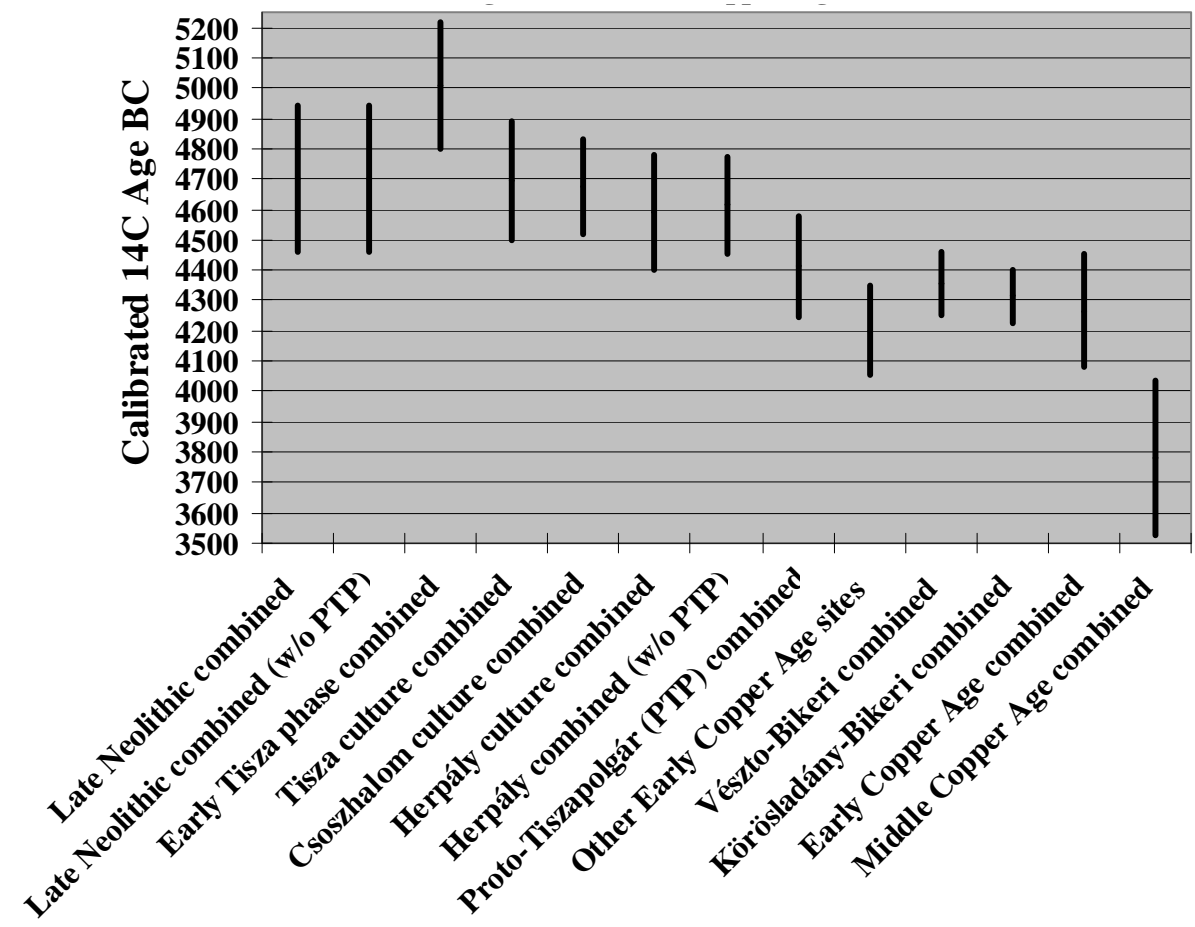

Figure 4 Summed probabilities at the $68.3 \%(1 \sigma)$ confidence interval for calibrated ${ }^{14} \mathrm{C}$ dates from Late Neolithic and Copper Age sites in the macroregion. The CALIB 5.01 program and IntCal04 curve were used. The summed probabilities for all 107 Late Neolithic (combined) samples are 5021-4402 cal BC. The summed probabilities for 103 Late Neolithic samples without (w/o) the 4 Proto-Tiszapolgár phase dates are nearly the same: 5025-4450 cal BC. The results for 39 early Tisza phase (combined) samples from Tápé-Lebő-A (17), Hódmezôvásárhely-Kökénydomb (10), Szegvár-Túzköves (8), and Vésztô-Mágor (Late Neolithic levels 3 and 4, four samples) are 5216-4856 cal BC. The results for 29 samples from Tisza culture (combined) sites at Hódmezóvásárhely-Gorzsa (26), Kisköre-Gát (2) and Deszk-Ordos (1) are 4893-4497 cal BC. The summed probabilities ( $1 \sigma)$ for 8 Csőszhalom culture (combined) samples from Polgár-Csôszhalom (6), Bodrogzsadány-Akasztószer (1), and the Tiszapolgár-Basatanya cemetery (1) are 4942-4374 cal BC. The results for 27 Herpály culture (combined) samples from Berettyóújfalu-Herpály (25 samples, including 3 Proto-Tiszapolgár phase dates), Berettyóújfalu-Szilhalom (1), and EsztárFenyvespart (1) are 4717-4455 cal BC. Without the 3 Proto-Tiszapolgár phase dates (w/o PTP), the summed probabilities $(1 \sigma)$ are $4721-4452 \mathrm{cal} \mathrm{BC}$. When the 3 Proto-Tiszapolgár phase samples from the Berettyoúffalu-Herpály tell are combined with the Proto-Tiszapolgár phase sample from Deszk-Vénó the results are 4579-4243 cal BC. Summed probabilities for 15 other Early Copper Age samples from Tiszapolgár-Basatanya (6), Bélmegyer-Mondoki domb (1), Méhkerék 23 (1), Vésztő-Mágor (1), Tiszapolgár (1), and Hajdúböszörmény-Ficsori-tó-dúlő cemetery (5) are 4348-4052 cal BC (samples from Vésztố-Bikeri and Körösladány-Bikeri are not included). The results for 22 (combined) Early Copper Age samples from Vésztó-Bikeri are 4459-4253 cal BC, and the summed probabilities for 10 (combined) Early Copper Age samples from Körösladány-Bikeri site are $4401-4227 \mathrm{cal} \mathrm{BC}$. The results for all 47 (combined) Early Copper Age samples are 4455-4079 cal BC. The combined results for 14 Middle Copper Age samples from Tiszapolgár-Basatanya (Bodrogkeresztúr Culture, 10 samples) and Tiszalúc-Sarkad (Hunyadihalom culture, 4 samples) are 4037-3523 cal BC. See Table 2 for summed probabilities for individual samples and sites. Most dates for the Late Neolithic Tisza-Csốszhalom-Herpály complex are from tells at Hódmezôvásárhely-Gorzsa, Polgár-Csốszhalom, and Berettyóújfalu-Herpály. 


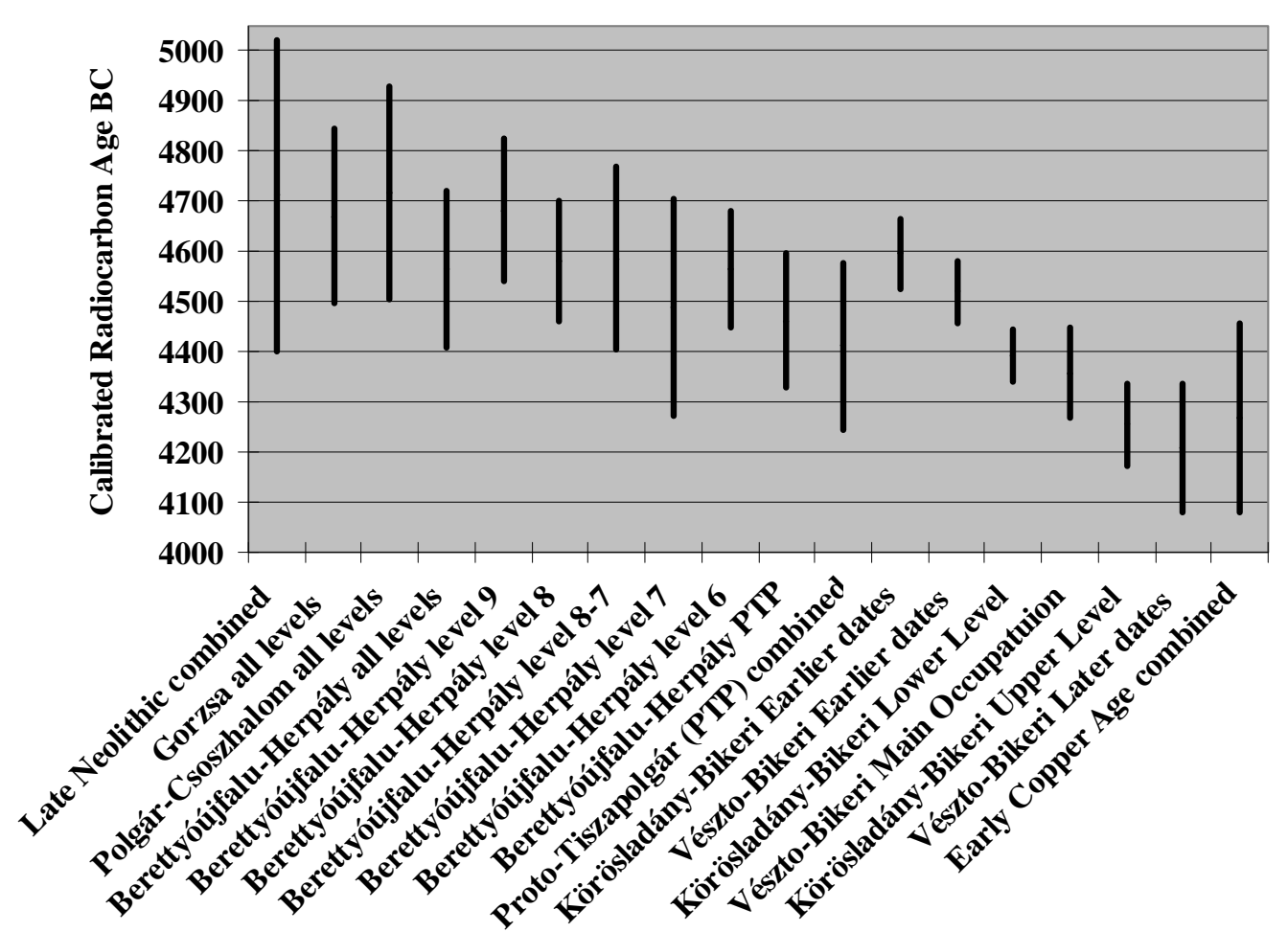

Figure 5 Summed probabilities at the $68.3 \%(1 \sigma)$ confidence interval for calibrated ${ }^{14} \mathrm{C}$ dates for all 107 Late Neolithic samples, from Late Neolithic tells at Hódmezővásárhely-Gorzsa (Gorzsa) and Polgár-Csôszhalom, and Proto-Tiszapolgár Levels at Berettyóúffalu-Herpály, occupation phases and earlier dates at the Early Copper Age Vésztó-Bikeri and Körösladány-Bikeri sites in the microregion, and the 47 Early Copper Age dates combined. The CALIB 5.01 program and IntCal04 curve were used. The summed probabilities $(1 \sigma)$ for 107 Late Neolithic samples: 5021-4402 cal BC; for 26 samples from Hódmezővásárhely-Gorzsa (Gorzsa): 4846-4495 cal BC; for 6 samples from Polgár-Csőszhalom: 4942-4374 cal BC. Sample sizes and 1- $\sigma$ ranges for the levels at Berettyóújfalu-Herpály are: All levels (including Proto-Tiszapolgár): 4720-4407 cal BC (27 samples); Level 9: 4825-4541 cal BC (3 samples); Level 8: 4702-4462 cal BC (8 samples); Levels 8-7: 4769-4403 cal BC (4 samples); Level 7: 4705-4273 cal BC (5 samples); Level 6: 4682-4449 cal BC (5 samples); Proto-Tiszapolgár levels (5 and 6-5): 4596-4328 cal BC (3 samples). Two earlier (older) dates from Körösladány-Bikeri: 4666-4526 cal BC; 3 earlier dates from Vésztô-Bikeri: $4582-$ 4456 cal BC; 2 dates from the lower level (first occupation phase) at Körösladány-Bikeri: 4445-4341 cal BC; 15 dates from the main occupation phase at Vésztó-Bikeri: 4448-4269 cal BC; 6 dates from the upper level (second occupation phase) at Körösladány-Bikeri: 4336-4173 cal BC; 4 later (younger) dates from Vésztő-Bikeri: $4335-4079$ cal BC; and the 47 combined Early Copper Age dates: 4455-4079 cal BC.

We recalibrated the published dates from Berettyóúffalu-Herpály (Appendices 1 and 2). The ranges for the summed probabilities were $284 \mathrm{yr}$ for Level 9, $240 \mathrm{yr}$ for Level 8, $366 \mathrm{yr}$ for Levels 8-7, $432 \mathrm{yr}$ for Level 7, and $233 \mathrm{yr}$ for Level 6, while the summed probabilities for all of the Late Neolithic levels at Berettyóújfalu-Herpály spanned a 313-yr interval from 4720-4407 cal BC (Figure 5).

We also recalibrated 3 dates associated with Proto-Tiszapolgár contexts (Levels 5 and 6) at Berettyóújfalu-Herpály (Figure 5). The summed probabilities $(1 \sigma)$ for these recalibrated dates (Appendix 2) spanned a $268-\mathrm{yr}$ interval of $4596-4328 \mathrm{cal} \mathrm{BC}$, which is only slightly younger than the $372-\mathrm{yr}$ interval for the entire Berettyóújfalu-Herpály tell (4720-4407 cal BC, $1 \sigma$ ). We combined these 3 dates with a single Proto-Tiszapolgár context date from the site of Deszk-Vénó (Figure 4, Appendices 1 and 2). The summed probabilities for these 4 Proto-Tiszapolgár dates produced a 336-yr inter- 
val of $4579-4243 \mathrm{cal} B C(1 \sigma)$, which is very close to the span of 4570-4270 cal BC that Hertelendi et al. (1995) estimated for the Proto-Tiszapolgár phase. A recent ${ }^{14} \mathrm{C}$ date from an eastern Slovakian Proto-Tiszapolgár site (4607 $\pm 55 \mathrm{cal} \mathrm{BC}$, Kaminská 2007) is slightly earlier than this time interval. This small collection of calibrated ${ }^{14} \mathrm{C}$ dates would place the Proto-Tiszapolgár phase (about 4600$4250 \mathrm{cal} \mathrm{BC}$ ) in an overlapping position between the Tisza-Herpály-Csôszhalom complex (about 4900-4450 cal BC) and the span of the Early Copper Age (about 4400/4500-4000 cal BC).

The extent and duration of the Proto-Tiszapolgár phase is not the same in all parts of the Great Hungarian Plain. In Slovakia, the term Proto-Tiszapolgár is used to refer to settlements that can be distinguished from Late Neolithic and Early Copper Age sites (e.g. Kaminská 2007; Šiška 1968). At the center of the plain, Proto-Tiszapolgár levels are often found on the top of Neolithic tells. These upper levels contain Tiszapolgár-like ceramic assemblages that include dark, lightly burnished, vessels decorated with lugs (see Kalicz and Raczky 1987b:125; Horváth 1987:42). Proto-Tiszapolgár contexts at tell sites such as Berettyóúffalu-Herpály (4596-4328 cal BC) are contemporary with initial Early Copper Age Tiszapolgár culture occupations at settlements such as Vésztó-Bikeri and Körösladány-Bikeri (4459-4227 cal BC), which are located only a few dozen km away (Figure 2). These dates also provide temporal contexts for the process of settlement establishment and abandonment between those 2 adjacent Early Copper Age sites and the Vésztô-Mágor tell, located $2 \mathrm{~km}$ to the north (Hegedús and Makkay 1987; see Figures 2 and 3).

By comparing these macroregional patterns with regional and microscalar trends, we can identify how the cultural processes that differentiated the Neolithic from the Copper Age played out at these more intimate social scales.

\section{REGIONAL SHORT-TERM PATTERNS: THE TRANSITION TO THE COPPER AGE IN THE KÖRÖS-BERETTYÓ REGION}

These broader temporal and geographic sequences are further enhanced by additional dates from new excavations that help clarify the chronological position of the Early Copper Age. In their calculations, Hertelendi et al. (1995) and Gläser (1996) used 8 dates to establish the interval of the Early Copper Age on the Great Hungarian Plain. Six of those Early Copper Age dates were from the early phase at the Tiszapolgár-Basatanya cemetery, 1 date was from Bélmegyer-Mondoki domb, and another was from the Méhkerék 23 site (Appendix 1). Hertelendi et al. (1995:242) proposed a 44103760 cal BC timespan for the period, while Gläser (1996) used OxCal v 2.13 to put the Early Copper Age between 4450 and $3800 \mathrm{cal} \mathrm{BC}$ (Figure 1).

We used the CALIB 5.01 program to recalibrate these 8 published Early Copper Age ${ }^{14} \mathrm{C}$ dates, and added 2 new dates from Tiszapolgár levels at Vésztó-Mágor, an unpublished date from "Tiszapolgár" (possibly from Tiszapolgár-Basatanya) and 5 new dates from the Hajdúböszörmény-Ficsori-tó-dúló cemetery (Kovács and Váczi 2007; see Appendices 1 and 2). The summed probabilities for these 15 Early Copper Age samples ( $1 \sigma$ ) produced a shorter 296-yr span of 4348-4052 cal BC that did not overlap the recalibrated Late Neolithic dates, but did overlap the Proto-Tiszapolgár dates (Figure 4). These new Tiszapolgár dates push the end of the Early Copper Age back 200 yr to 4000 cal BC, which is more in line with the currently accepted dates for the Early Copper Age (4500/ $4400-4000$ cal BC, with a Proto-Tiszapolgár phase of 4500-4400 cal BC between it and the Late Neolithic period of 5000-4500 cal BC, see Figure 1, Parkinson 2006a; Raczky 1995).

When we used CALIB 5.01 to calibrate samples collected during our own excavations at 2 other settlements in the Vésztô microregion, the estimated beginning of the Early Copper Age was pushed back to 4460 cal BC. These include 22 new dates from Vésztó-Bikeri and 10 new dates from Körös- 
ladány-Bikeri (Appendices 1 and 2). The summed probabilities $(1 \sigma)$ for all 22 dates from VésztóBikeri range from 4459-4253 cal BC, while the summed probabilities $(1 \sigma)$ for the 10 dates from Körösladány-Bikeri were 4401-4227 cal BC (Figure 4). These dates fall at the very beginning of the time interval that Hertelendi et al. (1995) calculated for the Early Copper Age period (4410-3760 cal BC). Although they do not overlap the timespan for the summed probabilities $(1 \sigma)$ for the Late Neolithic Tisza and Csốszhalom cultures, they do overlap with dates for the Herpály culture and are contemporary with much of the Proto-Tiszapolgár phase at the Berettyóújfalu-Herpály tell and the Deszk-Vénó site (Figure 4). The 2 Early Copper settlements in the Vésztó microregion were established not long after the end of the 10-generation-long Late Neolithic occupation sequences at the major tells of the Tisza-Herpály-Csószhalom complex, and were contemporary with the final Late Neolithic and Proto-Tiszapolgár occupation phases at the Berettyoújfalu-Herpály tell.

The summed probability $(1 \sigma)$ range for all 47 recalibrated early Copper Age dates in our database (22 from Vésztô-Bikeri, 10 from Körösladány-Bikeri, and 15 from Tiszapolgár contexts at other sites) is 4455-4079 cal BC (Figure 4), putting the Tiszapolgár timespan back in an interval that matches the position of the Early Copper Age in the revised chronology for the Great Hungarian Plain (4500/4400-4000 cal BC; see Raczky 1995), and no longer overlapping the timespan for the Middle Copper Age (4000-3500/3400 cal BC).

These recalibrated ${ }^{14} \mathrm{C}$ dates do not show as much overlap between the Late Neolithic, Early Copper Age, and Middle Copper Age as the earlier chronologies (Forenbaher 1993; Hertelendi et al. 1995; Gläser 1996), but there is significant continuity in material culture and social organization between the Late Neolithic, Early Copper Age, and Middle Copper Age on the plain. Based on these results, we suggest that the transition to the Early Copper Age took several centuries and began $\sim 4550 \mathrm{cal}$ $\mathrm{BC}$ at the end of the Late Neolithic period. Our investigations at 2 small Early Copper Age settlements in the Vésztô microregion, and the calibrated dates from those sites, indicate that changes in house size, burial practices, exchange patterns, and settlement organization during the Early Copper Age were more rapid, and spanned only a few generations (rather than centuries) in the Körös region.

\section{MICROREGIONAL AND SHORT-TERM PATTERNS: THE BEGINNING OF THE COPPER AGE IN THE VÉSZTŐ MICROREGION}

To place these regional patterns in perspective, it is helpful to see how the changes that characterize the end of the Neolithic played out at adjacent sites that were inhabited by related social units within a specific locality. To this end, we discuss the results of our analysis of 3 settlements within the Vésztő microregion: Vésztő-Bikeri and Körösladány-Bikeri (which are located only $70 \mathrm{~m}$ apart) and the well-known Vésztô-Mágor tell (which is just $2 \mathrm{~km}$ to the north, see Figure 3 and Hegedús and Makkay 1987).

Results of a $t$ test showed that the 22 calibrated ${ }^{14} \mathrm{C}$ dates from the Early Copper Age Tiszapolgár culture site of Vésztó-Bikeri are statistically different at the $95 \%$ level $(t=105.81$, which is larger than the critical value of $t=32.7$, at the 0.05 level when $d f=21$ ). The $t$ test results for the 10 calibrated ${ }^{14} \mathrm{C}$ dates from the nearby ECA Tiszapolgár culture site of Körösladány-Bikeri also showed that the dates are statistically different at the $95 \%$ level $(t=102.37$, critical value $=16.9, d f=9,0.05$ level). The ${ }^{14} \mathrm{C}$ samples from these sites were taken from several different depositional contexts, but most of the dates were from the fill of pits, wells, house wall trenches, and the circular palisades and ditches that surround the sites. As a result, most of the samples correspond to the end of the occupation episodes at the sites when the inhabitants were filling in and covering over features. At VésztóBikeri, only 2 samples may be associated with activities that took place before the site was aban- 
doned (Figure 6). Similarly, all of the ${ }^{14} \mathrm{C}$ samples from Körösladány-Bikeri derived from the fill of large bell-shaped storage/refuse pits, wall trenches, and ditches (Figure 7).

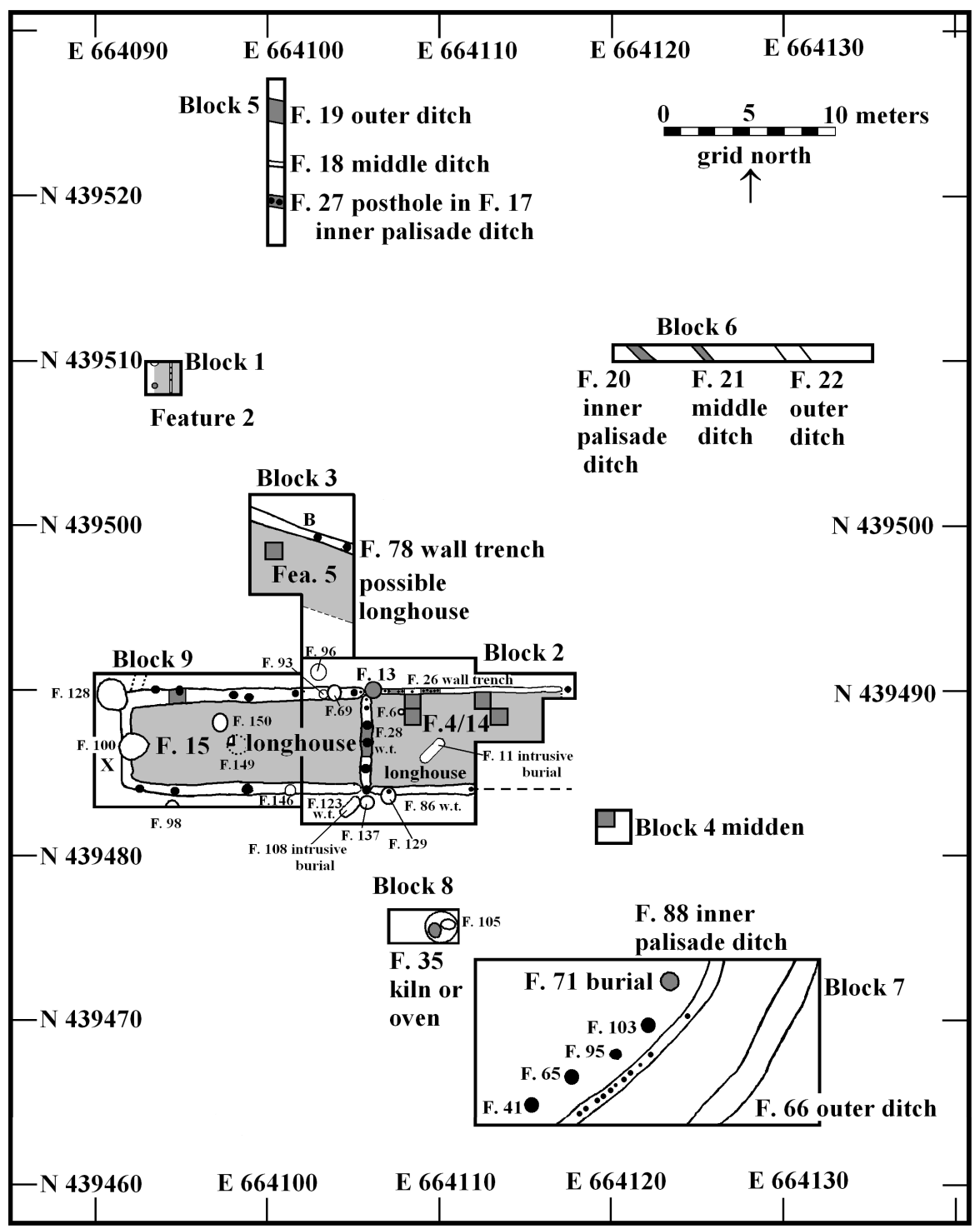

Figure 6 Plan of excavation blocks and Early Copper Age features at Vésztő-Bikeri showing where ${ }^{14} \mathrm{C}$ samples were taken. The sampled features and EUs (small squares) are dark shaded. Light shaded areas are floors of longhouse structures. Different feature numbers were used for the palisade and ditches in different Excavation blocks. Intrusive burials are from the Hungarian Conquest period (10th century AD).

Vésztó-Bikeri. The Bayesian and contextual analysis of the 22 calibrated ${ }^{14} \mathrm{C}$ dates from Vésztó-Bikeri suggested that there were 3 groups of dates. The contexts for these ${ }^{14} \mathrm{C}$ samples is shown on Figure 6 and listed in Appendix 1. The first group of 15 calibrated dates came from deposits that were (1) on or in the floor of the longhouse structure Feature 4/14 (Beta-162068 and Beta-179783), (2) in the fill of the wall-trenches of 2 structures that shared a common wall (Features 4/14 and 15, Beta- 


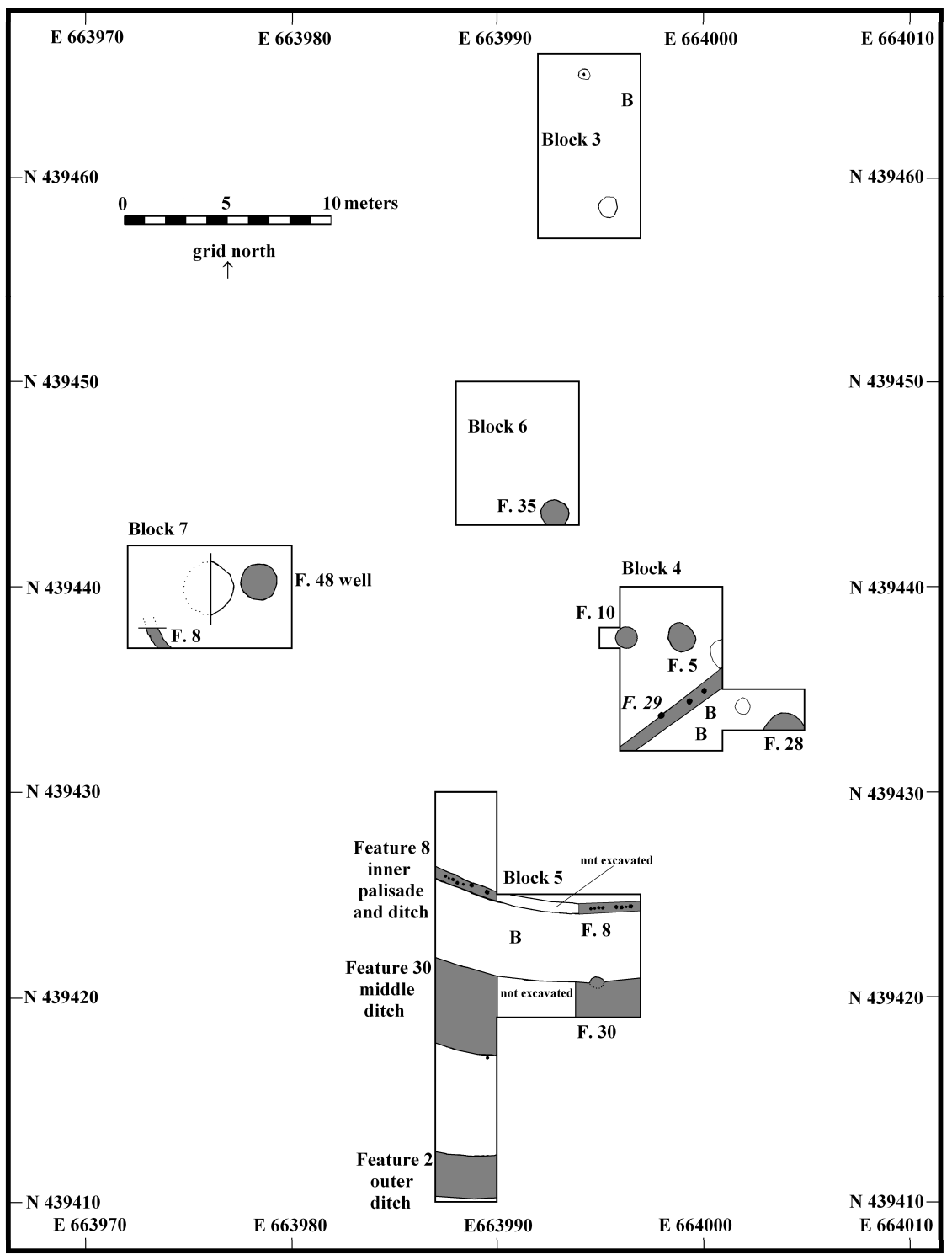

Figure 7 Plan of Excavation Blocks and Early Copper Age features at Körösladány-Bikeri showing where ${ }^{14} \mathrm{C}$ samples were taken. The sampled features are dark shaded. Letter " $\mathrm{B}$ " marks the location of infant burials that were laid on the surface.

179789, Beta-179788, Beta-179786, and Beta-179787) - the eastern wall trench of Feature 15 was reused as the western wall of feature 4/14; (3) in the fill of the north wall trench of the Feature 15 longhouse (Beta-214593); (4) in deposits at the base of the plowzone over Feature 5, another possible longhouse (Beta-162070); (5) in the fill of Feature 13, a bell-shaped pit at the NW corner of the Feature 4/14 longhouse (Beta-179785 and Beta-179784); (6) from charcoal associated with the Feature 71 burial that was placed above an extracted post inside of the palisade (Beta-214589); (7) in the fill of the inner palisade ditch Feature 20 (Beta-179792); (8) from Feature 27, a posthole in the inner palisade ditch (Beta-179791); (9) in the fill of the outer ditch, Feature 19 (Beta-179790); and (10) in 
the fill of the middle ditch, Feature 21 (Beta-179793). A $t$ test on the first 14 of these dates showed that they are statistically similar at the $95 \%$ level $(t=19.56$, critical value $=22.4, d f=13,0.05$ level $)$. When the 15th date (Beta-179793) is added to the group, results of a $t$ test showed that the dates are statistically different at the $95 \%$ level, but the results are very close $(t=24.37$, critical value $=23.7$, $d f=14,0.05$ level). In the Bayesian analysis for the 15 dates with OxCal $\mathrm{v} 4$, the agreement indices for all the dates were $\geq 73$, so they seem to form a valid group of dates that can be used to estimate the time of the main occupation episode at Vésztô-Bikeri. The summed probabilities for these 15 dates $(1 \sigma)$ ranged from 4448-4269 cal BC for this main occupation phase, while the Bayesian analysis put the starting boundary between 4407 and $4356 \mathrm{cal} \mathrm{BC} \mathrm{(mean}=4395 \mathrm{cal} \mathrm{BC}$ ) and the ending boundary between 4349 and $4314 \mathrm{cal}$ BC (mean = $4322 \mathrm{cal} \mathrm{BC)}$. The estimated span (or duration) of the main occupation at Vésztó-Bikeri was 0-76 yr, with a mean of $63 \mathrm{yr}$ and a median of $52 \mathrm{yr}-$ or for 1 or 2 generations.

Four of the ${ }^{14} \mathrm{C}$ dates from Vésztő-Bikeri are later (younger) than the 15 dates from the main occupation phase. Results of a $t$ test show that these dates are statistically the same at the $95 \%$ level $(t=$ 5.07 , critical value $=7.81, d f=3,0.05$ level). Two dates are from deposits in the daub or cultural layers that cover the floor layers of a longhouse structure (Beta-179782 and Beta-162067), 1 date is from the fill in the oven or kiln (Feature 35) (Beta-214592), and the fourth is from a ring midden surrounding the settlement (Beta-162071). Summed probabilities $(1 \sigma)$ for these 4 dates range from 4335-4079 cal BC. Bayesian analysis puts the starting boundary for these younger dates between 4377 and $4254 \mathrm{cal} \mathrm{BC}$ (mean = $4357 \mathrm{cal} \mathrm{BC}$ ) and the ending boundary between 4256 and $4048 \mathrm{cal}$ $\mathrm{BC}($ mean $=4113 \mathrm{cal} \mathrm{BC})$. The duration of this later phase was estimated at 0-143 $\mathrm{yr}(\mathrm{mean}=$ $109 \mathrm{yr}$, median $=97 \mathrm{yr}$ ). These dates may be on younger charred materials that were deposited in the ring midden that encircles the site, incorporated into the covering deposits when the longhouse structure walls were burned and leveled, and deposited when the kiln/ovens were abandoned and covered over. These activities may have taken place after the inhabitants of Vésztô-Bikeri had relocated their settlement to the adjacent Körösladány-Bikeri site.

Körösladány-Bikeri. Two occupation levels were exposed at the Körösladány-Bikeri site. The contexts for the ${ }^{14} \mathrm{C}$ samples are listed in Appendix 1 and shown in Figure 7. Only $2{ }^{14} \mathrm{C}$ samples derive from the lower level (the first occupation phase). One came from the fill of a trench in Excavation Block 4 (Beta-234308), and one from the fill of a bell-shaped storage/refuse pit (Beta-234307). Results of a $t$ test show that these dates are statistically the same at the $95 \%$ level $(t=0.5$, critical value $=3.84, d f=1,0.05$ level). The summed probabilities $(1 \sigma)$ for the 2 dates range from $4445-$ $4341 \mathrm{cal}$ BC. The Bayesian analysis puts the starting boundary for the lower level between 4512 and $4355 \mathrm{cal} \mathrm{BC}($ mean $=4510 \mathrm{cal} \mathrm{BC})$ and the ending boundary for the first occupation phase between 4433 and $4267 \mathrm{cal} \mathrm{BC} \mathrm{(mean} \mathrm{=} 4271 \mathrm{cal} \mathrm{BC}$ ). The estimated span of the first occupation phase on the lower level is $0-39 \mathrm{yr}$, with a mean of $29 \mathrm{yr}$-about 1 generation. These dates fall within the timespan of the main occupation phase at Vésztô-Bikeri (Figure 5), suggesting that the settlement at Körösladány-Bikeri was established and occupied before Vésztő-Bikeri was abandoned entirely.

Six calibrated ${ }^{14} \mathrm{C}$ dates derive from the upper level (later occupation phase) at the KörösladányBikeri site. Results of a $t$ test show that the 6 dates are statistically the same at the $95 \%$ level $(t=$ 1.62 , critical value $=11.1, d f=5,0.05$ level $)$. The summed probabilities $(1 \sigma)$ for the dates were 4336-4173 cal BC. The Bayesian analysis puts the starting boundary for the upper level between 4346 and $4263 \mathrm{cal} \mathrm{BC}$ (mean $=4313 \mathrm{cal} \mathrm{BC}$ ) and the ending boundary for the second occupation phase between 4303 and $4223 \mathrm{cal} \mathrm{BC}$ (mean = $4244 \mathrm{cal} \mathrm{BC}$ ). The duration of the second occupation phase on the upper level is estimated at 0-54 yr, with a mean of $44 \mathrm{yr}$ - or a little more than 1 generation. The dates were run on samples from various deposits, including 3 from bell-shaped storage/ 
refuse pits (Beta-234312, Beta-214595, and Beta-234306). Two dates were on samples from a well (Beta-234313 and Beta-234314), and 1 date was on samples recovered in the bottom fill layer of the circular outer ditch that surrounded the site (Beta-214596). This outer ditch seems to have been excavated when the Körösladány-Bikeri site was expanded during the second occupation phase. The span of the dates from the upper level or second occupation phase at Körösladány-Bikeri falls within the time interval for the 4 younger dates from Vésztő-Bikeri (Figure 5). It seems like the kilns or ovens at Vésztő-Bikeri were used when the Körösladány-Bikeri site had reached it maximum size during this second habitation phase (represented by the upper level).

Early Outliers. Three ${ }^{14} \mathrm{C}$ dates from Vésztô-Bikeri are earlier (older) than the 15 dates from the main occupation. Results of a $t$ test show that the dates are statistically the same at the $95 \%$ level $(t=$ 1.60 , critical value $=5.99, d f=2,0.05$ level). Two of the dates are from deposits on or in the floor of a longhouse structure (Beta-162066 and Beta-162069). The third is from the fill of a circular pit that may be associated with another structure (Beta-162065, see Appendix 1, Figure 6). The range for summed probabilities $(1 \sigma)$ for these dates is $4582-4456 \mathrm{cal} \mathrm{BC}$. These dates may have been acquired from older, perhaps reused, charred materials that later were incorporated into the pit fill and floor deposits.

Two dates on samples from the fill of the ditches at Körösladány-Bikeri also were older than the dates from the 2 habitation levels at the settlement. One sample came from a posthole in the inner palisade ditch (Beta-214597), while the other came from the fill of the large, deep middle ditch (Beta-234310, see Appendix 1 and Figure 7). Results of a $t$ test showed that the dates are statistically the same at the $95 \%$ level $(t=0.03$, critical value $=3.84, d f=1,0.05$ level $)$. The range for the summed probabilities $(1 \sigma)$ is $4666-4526 \mathrm{cal} \mathrm{BC}$. These dates also seem to have been acquired from older charred materials that later were incorporated into the ditch fill.

These early dates from Tiszapolgár contexts at Vésztô-Bikeri and Körösladány-Bikeri fall at or near the end of sequences associated with Late Neolithic contexts at other sites in the region (Figure 5). It is possible that the inhabitants at these 2 small sites "curated" posts from palisades and structures at Late Neolithic tells and flat sites nearby, such as Vésztô-Mágor, a multicomponent tell only $2 \mathrm{~km}$ away. Unfortunately, this tell is not as well dated as some of the other tells of the Tisza-HerpályCsôszhalom complex listed in Appendix 1. The 4 published dates from Late Neolithic levels 3 and 4 at Vésztó-Mágor fall at the beginning of the Late Neolithic period (early Tisza, see Appendix 2), while a single bone sample from the later Tiszapolgár occupation at the tell (Beta-162061) produced a date of 4345-4081 cal BC $(1 \sigma)$. That date would line up with the younger dates from Vésztő-Bikeri and the upper level at Körösladány-Bikeri shown in Figure 5, suggesting that the tell and the small dispersed settlements all may have been inhabited during a later phase of the Early Copper Age.

\section{The Early Copper Age in Context}

Figure 5 shows the temporal relationship between the calibrated ${ }^{14} \mathrm{C}$ dates from the different occupations phases at the Tiszapolgár settlements of Vésztó-Bikeri and Körösladány-Bikeri, the combined dates from all 47 Early Copper Age Tiszapolgár sites in our database, the dates from ProtoTiszapolgár contexts, Late Neolithic dates from 3 tells of the Tisza-Herpály-Csôszhalom complex, the 107 Late Neolithic dates combined, and dates from different levels at the Berettyóújfalu-Herpály tell. The earlier dates from Vésztó-Bikeri and Körösladány-Bikeri (about 4650-4450 cal BC)—both Early Copper Age sites-are contemporary with Late Neolithic contexts elsewhere (although the dates from the Early Copper Age sites may be on older recycled wooden posts or charred materials). The first habitation episodes at both Early Copper Age settlements (about 4450-4250 cal BC) over- 
lap the dates from Late Neolithic and Proto-Tiszapolgár levels at Berettyóúffalu-Herpály, ${ }^{9}$ a nearby tell on the Berettyó River in the Körös region (Figures 2 and 5).

These dates from the initial occupations at Vésztô-Bikeri and Körösladány-Bikeri also are earlier than the dates from other Tiszapolgár settlements and cemeteries, which range from 4348-4052 cal BC (Figures 4 and 5). Patterns associated with the Tiszapolgár culture seem to have developed earlier in the Vésztó microregion than at other sites in the Körös region or in the northern part of the Great Hungarian Plain where Proto-Tiszapolgár phase occupations have been identified (Appendices 1 and 2; Figure 4).

The final occupation phases at Vésztó-Bikeri and Körösladány-Bikeri (about 4350-4050 cal BC), however, are contemporary with the range of dates from other Tiszapolgár cemeteries and settlements, including the Early Copper Age occupation at the Vésztô-Mágor tell (4345-4081 cal BC). The earlier phase of the Early Copper Age in the Vésztố microregion is temporally and spatially contiguous with the terminal phase of the Late Neolithic Tisza-Herpály-Csószhalom complex. The later phase of the Early Copper Age is marked by the later habitation level at Körösladány-Bikeri (without longhouses) with continued use of some features at Vésztô-Bikeri, and with a Tiszapolgár settlement occupation on the Vésztó-Mágor tell. During this later phase of the Early Copper Age, formal cemeteries away from settlements first appeared across the Plain, after new patterns of settlement and household organization were established during the early phase of the Early Copper Age.

At the microregional scale, calibrated ${ }^{14} \mathrm{C}$ dates permit us to document changes in settlement and landscape use between nearby settlements, and to tease apart the timing of the various processes that characterize the Neolithic-Copper Age transition throughout the region. Settlement dispersal and tell abandonment preceded changes in household and settlement organization in the Vésztó microregion. All these processes preceded the emergence of large formal Tiszapolgár cemeteries located away from the small settlements.

\section{CONCLUSIONS: TEMPORAL SCALES, ARCHAEOLOGICAL PATTERNS, AND SOCIAL PRO- CESSES}

This article set out to discuss the relationship between chronologies based on calibrated ${ }^{14} \mathrm{C}$ dates and their expressions in the archaeological record. In attempting to model the various changes that characterize the end of the Neolithic on the Great Hungarian Plain, we have approached the topic from several different temporal, geographic, and social scales. Due to the nature of ${ }^{14} \mathrm{C}$ dates and the archaeological record itself, the degree of chronological resolution available to the researcher is related directly to the scale of analysis. At broader geographic and temporal scales, the absolute ${ }^{14} \mathrm{C}$ chronology for the Great Hungarian Plain is well supported by the distribution of archaeological assemblages associated with different cultures in the region. But at the regional and microregional scales, the ${ }^{14} \mathrm{C}$ dates indicate patterns of geographic and temporal variability in the social processes - and the material correlates of those processes-that we use to differentiate the Neolithic from the Copper Age. By approaching the topic at multiple scales, we have been able to examine the onset, duration, and extent of the processes that differentiate these macroscale chronological periods (i.e. Neolithic and Copper Age).

\footnotetext{
${ }^{9}$ There is significant overlap between the range for the summed probabilities $(1 \sigma)$ for the main occupation at Vésztô-Bikeri, the lower occupation level at Körösladány-Bikeri, the summed probability range for Late Neolithic levels 8-7 and level 7 at Berettyóújfalu-Herpály, and the Proto-Tiszapolgár levels at that tell (Figure 5).
} 
The groups of calibrated ${ }^{14} \mathrm{C}$ dates examined in this study can be aligned in a series of relatively short, overlapping cultural phases that span the Late Neolithic period and the Early Copper Age on the Great Hungarian Plain. Our recalibration of some of the Late Neolithic dates supports the findings of Ede Hertelendi and his colleagues that several Late Neolithic and Early Copper Age cultural complexes were contemporary and/or overlapping. The 4 Proto-Tiszapolgár dates ( 3 from Berettyóújfalu-Herpály) suggest a 300-yr timespan for the transitional period between the Late Neolithic and Early Copper Age, but more samples from sites in different areas within the Great Hungarian Plain have to be collected and analyzed in order to develop a more precise timeframe for this transition. We enlarged the sample of calibrated Early Copper Age ${ }^{14} \mathrm{C}$ dates from 15 to 47 , and used the expanded sample to show that the Early Copper Age period lasted from about 4500 to $4000 \mathrm{cal}$ BC - consistent with the time range that Raczky (1995) proposed, but slightly older than the timeframes that others had established using older calibration programs and calibration curves (see Figure 1).

Our analyses of calibrated dates revealed that after living on large nucleated tells for some 10 generations, agriculturalists of the Tisza-Herpály-Csôszhalom complex dispersed to small fortified sites like Vésztố-Bikeri and Körösladány-Bikeri (and other small sites without ditches and palisades) but the dispersal began before the tells were entirely abandoned at the end of the Late Neolithic period ( 4550 cal BC).

While there were many innovations and changes at the end of the late Neolithic period, the significant cultural continuity between the Late Neolithic and Early Copper Age groups is revealed in many aspects of material culture, but also in traditions such as dismantling and covering over houses and filling in pits, wells, and ditches at the end of each occupation episode. But instead of rebuilding on top of each layer and forming vertical tell sequences (like their Late Neolithic predecessors), Early Copper Age groups built new structures and features adjacent to the abandoned ones-they moved "horizontally" rather than "vertically." This is illustrated in the case of Feature 15, an early longhouse structure built in the center of Vésztó-Bikeri. After this house was abandoned, and its wall trenches were filled in, a new structure was built right next to it. The west wall of the new longhouse, Feature 4/14, was constructed in the abandoned and filled-in east wall trench of Feature 15 (Figure 6). When the settlement at Vésztó-Bikeri was finally abandoned, instead of building a new settlement on top of the old, the group seems to have moved $70 \mathrm{~m}$ west and established the new settlement at Körösladány-Bikeri (Figures 3 and 7).

The shift from vertical to horizontal (or lateral) movement of structures, features, and settlements is a significant cultural characteristic that distinguishes the Early Copper Age from the Late Neolithic, but there also is much evidence for cultural continuity. The $80-100 \mathrm{~cm}$ vertical stratigraphy at Vésztő-Bikeri, Körösladány-Bikeri, and in the Tiszapolgár levels at Vésztó-Mágor implies that the Early Copper Age farmers continued the building and leveling activities that went on at the multigeneration Neolithic tells and tell-like settlements-but on a smaller scale and over a few generations instead of centuries. The dispersal of large nucleated populations from the tells to the small flat settlements began around $4500 \mathrm{cal} \mathrm{BC}$, or even earlier, but some of the tells might have not been abandoned entirely, and in the case of the large tell at Vésztó-Mágor, some were reoccupied after a hiatus of several centuries in the Early Copper Age (Hegedús and Makkay 1987; Parkinson et al. 2004b).

Although there are gaps in the occupation sequence at the Vésztô-Mágor tell, the calibrated ${ }^{14} \mathrm{C}$ dates from Vésztô-Bikeri and Körösladány-Bikeri reveal an unbroken cycle of habitation within the microregion. The 2 adjacent sites of Vésztő-Bikeri and Körösladány-Bikeri were both surrounded 
by substantial palisades and ditches, but the artifacts and floral and faunal materials from the 2 sites are nearly identical. It appears that construction of the younger Körösladány-Bikeri site began before the older Vésztó-Bikeri site was entirely abandoned. Timbers from the palisade and domestic structures at the older site may have been reused in the palisade at the new site. The older dates from the 2 settlements could be on charred posts that had been curated since the end of the Late Neolithic period. It also appears that when this 2-site multiple phase habitation cycle ended, the Early Copper Age groups filled in both sites and covered them over before moving on.

Due to the multiple intercepts in the calibration curve, we are not able to produce short, precise chronologies for the occupation phases at the tells and the small flat settlements. Stratigraphic studies and ethnographic parallels suggest the wattle-and-daub structures and palisades needed to be dismantled and replaced every $20 \mathrm{yr}$ or so, and our estimates from the Bayesian analyses indicate that the occupation episodes at these 2 Early Copper Age settlements spanned a generation or two.

As the aftershocks of the Radiocarbon Revolution continue to reverberate through our understanding of human prehistory, we find promise in a method that incorporates multiple scales of analysis. Having recovered from the immediate implications of the first ${ }^{14} \mathrm{C}$ revolution which forced prehistorians to dramatically rewrite their understanding of the temporal and social relationship between prehistoric societies, we now are afforded the opportunity to focus our efforts on fine-tuning specific chronological sequences. To that end, we have found it extremely helpful to work between several different temporal and geographic scales, using the patterns at 1 scale to help interpret those at the other scales.

The transition from the Neolithic to the Copper Age in the Carpathian Basin was marked by social processes that played out differently at several social, geographic and temporal scales. By analyzing the absolute chronological data at these different scales, we have been able to outline how macroregional period designations relate to archaeological patterns at the regional and microregional scales. Conversely, by placing those patterns into a broader geographic and temporal framework, we have been able to model what these grander period designations mean in terms of specific, local, social processes. We hope that this multiscalar approach will be helpful to those trying to understand similar relationships between macroscale period designations and their regional and microregional expressions in the archaeological record elsewhere in the world.

\section{ACKNOWLEDGMENTS}

Support for the Körös Regional Archaeological Project, including funds for ${ }^{14} \mathrm{C}$ dates run by Beta Analytic, Inc. was provided by grants from the National Science Foundation Research Experience for Undergraduates Program (REU-Sites), the NSF International Collaborative Research program (USA-Hungary), the Hungarian National Academy of Sciences, the Hungarian Scientific Research Fund (OKTA), the Wenner-Gren Foundation for Anthropological Research, the Munkácsy Mihály Museum, Békéscsaba, Hungary, the Ohio State University Department of Anthropology, College of Social and Behavioral Sciences, Office of Research, and Office of International Education, the Florida State University Department of Anthropology, Office of Research, and International Programs Office, and the Field Museum of Natural History. Éva Svingor of the Institute of Nuclear Research of the Hungarian Academy of Sciences at Debrecen provided us with a list of some of the conventional ${ }^{14} \mathrm{C}$ dates that had been used by the late Ede Hertelendi and his colleagues in their earlier analyses. These dates are listed, and recalibrated, in the appendices. Two anonymous reviewers provided us with useful comments that helped us clarify our ideas, and our text. We thank them and several other colleagues including Roderick Salisbury, Daniel Pullen, Michael Galaty, and William Lovis 
who also provided us with helpful critiques. Finally, we want to extend our gratitude to Pál Raczky and his colleague, Alexandra Anders, at the Loránd Eötvös Scientific University in Budapest for their assistance in helping us sort through some of the conventional dates. Köszönjünk szépen!

\section{REFERENCES}

Ambers J, Matthews K, Bowman S. 1987. British Museum natural radiocarbon measurements XX. Radiocarbon 29(2):177-96.

Ammerman A, Biagi P, editors. 2003. The Widening Harvest, the Neolithic Transition in Europe: Looking Back, Looking Forward. Boston: Archaeological Institute of America Colloquia \& Conference Papers 6. $343 \mathrm{p}$.

Ammerman A, Cavalli-Sforza L. 1973. A population model for the diffusion of early farming in Europe. In: Renfrew C, editor. The Explanation of Culture Change: Models in Prehistory. London: Duckworth. p 335-58.

Bánffy E. 1994. Transdanubia and eastern Hungary in the Early Copper Age. Jósa András Múzeum Évkönyve 36:291-6.

Bánffy E. 2007. Cultural contacts between Neolithic eastern and western Hungary (the findings of the 1957 Csôszhalom excavation). In: Kozowski JK, Raczky P, editors. The Lengyel, Polgar and Related Cultures in the Middle/Late Neolithic in Central Europe. Krakow: The Polish Academy of Arts and Sciences. p 71-81.

Bankoff HA, Winter FA. 1990. The later Aeneolithic in southeastern Europe. American Journal of Archaeology 94(1):175-91.

Benkő L, Horváth F, Horvatinčić N, Obelić B. 1989. Radiocarbon and thermoluminescence dating of prehistoric sites in Hungary and Yugoslavia. Radiocarbon 31(3):992-1002.

Blackwell PG, Buck CE, Reimer PJ. 2006. Important features of the new radiocarbon calibration curves. Quaternary Science Reviews 25(5-6):408-13.

Bognár-Kutzián I. 1963. The Copper Age Cemetery of Tiszapolgár-Bastanya. Budapest: Archaeologica Hungarica 42, Akadémiai Kiadó. 595 p.

Bognár-Kutzián I. 1972. The Early Copper Age Tiszapolgár culture in the Carpathian Basin. Budapest: Archaeologica Hungarica 48, Akadémiai Kiadó. 253 p.

Bognár-Kutzián I. 1985. Contribution to the prehistoric chronology of Hungary. Mitteilungen des Archäologischen Institutes der Ungarishen Akademie der Wissenschften 14:293-8.

Bognár-Kutzián I, Csongor É. 1987. New results of radiocarbon dating of archaeological finds in Hungary. In: Pécsi M, Kordos L, editors. Holocene Environment in Hungary: Contribution of the INQUA Hungarian National Committee to the XII ${ }^{\text {th }}$ INQUA Congress, Ottawa, 1987. Budapest: Akadémiai Kiadó. p 131-40.

Bökönyi S. 1974. History of Domestic Mammals in Central and Eastern Europe. Budapest: Akadémiai Kiadó. $597 \mathrm{p}$.
Bökönyi S. 1986. Environmental and cultural effects on the faunal assemblages of four large Fourth Millennium B.C. sites. A Béri Balogh Ádám Múzeum Évkönyve 13:69-88.

Bronk Ramsey C. 1995. Radiocarbon calibration and analysis of stratigraphy: the $\mathrm{OxCal}$ program. Radiocarbon 37(2):425-30.

Bronk Ramsey C. 2001. Development of the radiocarbon calibration program. Radiocarbon 43(2A):355-63.

Buck CE. 1999. Bayesian statistics for archaeology. In: Gaul W, Locarek-Junge H, editors. Classification in the Information Age. Berlin: Springer. p 547-54.

Buck CE. 2001. Applications of the Bayesian Statistical Paradigm. In: Brothwell DR, Pollard AM, editors. Handbook of Archaeological Sciences. New York: John Willey \& Sons. p 695-702.

Buck CE, Christen JA, James GN. 1999. BCal: an on-line Bayesian radiocarbon calibration tool. Internet Archaeology 7. http://intarch.ac.uk/journal/issue7/ buck_index.html.

Childe VG. 1929. The Danube in Prehistory. Oxford: Oxford University Press. 479 p.

Childe VG. 1939. The Orient and Europe. American Journal of Archaeology 43(1):10-26.

Demoule J-P, Perlès C. 1993. The Greek Neolithic: a new review. Journal of World Prehistory 7:355-416.

Forenbaher S. 1993. Radiocarbon dates and absolute chronology of the central European Early Bronze Age. Antiquity 67(255):218-56.

Fowles S. 2002. From social type to social process: placing 'tribe' in a historical framework. In: Parkinson WA, editor. The Archaeology of Tribal Societies. Archaeological Series Monograph \#15. Ann Arbor: International Monographs in Prehistory. p 13-33.

Frolking T. 2004. Soils, hydrology and Mid-Holocene settlement patterns in the central Körös basin, eastern Hungary. Geological Society of America, Abstracts with Programs 36(5):213.

Gimbutas MAE. 1997. The Kurgan Culture and the IndoEuropeanization of Europe: Selected Articles from 1952-1993. Dexter MR, Jones-Bley K, editors. Washington: Journal of Eastern European Studies Monograph 18. Institute for the Study of Man. 404 p.

Gkiasta M, Russell T, Shennan S, Steele J. 2003. Neolithic transition in Europe: the radiocarbon record revisited. Antiquity 77(295):45-62.

Gläser R. 1996. Zur absoluten Datierung der Vinča-Kultur anhand von ${ }^{14} \mathrm{C}$-Daten. In: Draşovean $\mathrm{F}$, editor. The Vinča Culture, Its Role and Cultural Connections. Timioara: The Museum of Banat. p 175-212.

Gyucha A, Parkinson W, Yerkes R. 2004. Kora rézkori 
településkutatás a Dél-Alföldön. Elzetes jelentés a Körös Regionális Régészeti Program 1998-2002 között végzett munkájáról. Studia Archaeologica 10: 25-52.

Gyucha A, Bácsmegi G, Fogas O, Parkinson WA. 2006. House construction and settlement patterns on an Early Copper Age site in the Great Hungarian Plain. Communicationes Archaologica Hungaria 2006:528.

Hegedűs K, Makkay J. 1987. Vésztô-Mágor: a settlement of the Tisza culture. In: Raczky P, editor. The Late Neolithic of the Tisza Region: A Survey of Recent Excavation and their Findings. Budapest-Szolnok: Szolnok County Museums, Kossuth Press. p 85-104.

Hertelendi E, Horváth F. 1992. Radiocarbon chronology of Late Neolithic settlements in the Tisza-Maros region, Hungary. Radiocarbon 34(3):859-66.

Hertelendi E, Kalicz N, Raczky P, Horváth F, Veres M, Svingor É, Futó I, Bartosiewicz L. 1995. Re-evaluation of the Neolithic in eastern Hungary based on calibrated radiocarbon dates. Radiocarbon 37(2):23944.

Hertelendi E, Svingor É, Raczky P, Horváth F, Futó I, Bartosiewicz L. 1998a. Radiocarbon chronology of the Neolithic and time span of tell settlements in eastern Hungary based on calibrated radiocarbon dates. In: Költ L, Bartosiewicz L, editors. Archaeometrical Research in Hungary II. Budapest-Kaposvár-Veszprém. p 61-8.

Hertelendi E, Svingor É, Raczky P, Horváth F, Futó I, Bartosiewicz L. 1998b. Duration of tell settlements at four prehistoric sites in Hungary. Radiocarbon 40(2): $659-65$.

Horváth F. 1985. Aspects of Late Neolithic changes in the Tisza-Maros region. A Béri Balogh Ádám Múzeum Évkönyve 13:89-102.

Horváth F. 1987. Hódmezővásárhely-Gorzsa a settlement of the Tisza culture. In: Raczky P, editor. The Late Neolithic of the Tisza Region: A Survey of Recent Excavations and Their Findings. Budapest-Szolnok: Szolnok County Museums, Kossuth Press. p 31-8.

Horváth F. 2000. Gorzsa and Gradeshnitsa: South Meets North in the Maros and Tisza Valley. In: Hiller S, Nikolov V, editors. Karanovo Band III. Beiträge zum Neolithikum in Südosteuropa. Vienna: Phoibos Verlag. p 359-73.

Horváth F. 2005. Gorzsa. Elzetes eredmények az újkkori tell 1978 és 1996 közötti feltárásából (Gorzsa. Preliminary results of the excavation of the Neolithic tell between 1978-1996). In: Bende L, Lrinczy G, editors. Hétköznapok Vénuszai. Hódmezővásárhely: Móra Ferenc Múzeum. p 51-83.

Horváth F, Hertelendi E. 1994. Contribution to the ${ }^{14} \mathrm{C}$ based absolute chronology of the Early and Middle Neolithic Tisza region. Jósa András Múzeum Évkönyve 36:111-33.
Kaiser T, Voytek B. 1983. Sedentism and economic change in the Balkan Neolithic. Journal of Anthropological Archaeology 2(4):323-53.

Kalicz N. 1970. Clay Gods: The Neolithic Period and Copper Age in Hungary. Budapest: Athenaeum Printing House. 82 p.

Kalicz N. 1985. On the chronological problems of the Neolithic and Copper Age in Hungary. Mitteilungen des Archäologischen Institutes der Ungarischen Akademie der Wissenschaften 14:21-51.

Kalicz N. 1988. Kultúraváltozások a korai és középs rézkorban a Kárpát-medencében (Culture changes in the Carpathian Basin during the Late Neolithic and Copper Age). Archaeologiai Értesít 114-115:3-15.

Kalicz N, Makkay J. 1977. Die Linienbandkeramik in der Grossen Ungarischen Tiefebene. Budapest: Studia Archaeologica 7, Akadémiai Kiadó. 385 p.

Kalicz N, Raczky P. 1987a. The Late Neolithic of the Tisza region: a survey of recent archaeological research. In: Raczky P, editor. The Late Neolithic of the Tisza Region: A Survey of Recent Excavations and their Findings. Budapest-Szolnok: Szolnok County Museums, Kossuth Press. p 11-29.

Kalicz N, Raczky P. 1987b. Berettyóújfalu-Herpály. In: Raczky P, editor. The Late Neolithic of the Tisza Region: A Survey of Recent Excavations and their Findings. Budapest-Szolnok: Szolnok County Museums, Kossuth press. p 105-25.

Kaminská L. 2007. Praveké osídlenie pieskovej duny Veká Mova v Čičarovciach (Vorgeschichtliche Ansiedlung der Sanddüne Veká Mova in Čičarovce). Slovenská Archeológia 55(2):203-60.

Knapp AB, editor. 1992. Archaeology and annales: time, space and change. In: Knapp B, editor. Archaeology, Annales and Ethnohistory. Cambridge: Cambridge university Press. p 19-34.

Kohl G, Quitta H. 1964. Berlin radiocarbon measurements I. Radiocarbon 6(1):308-17.

Kohl G, Quitta H. 1966. Berlin radiocarbon measurements II. Radiocarbon 8(1):27-45.

Kohl G, Quitta H. 1970. Berlin radiocarbon measurements IV. Radiocarbon 12(2):400-20.

Kovács K, Váczi G. 2007. The cemetery of the Early Copper Age Tiszapolgár culture at HajdúböszörményFicsori-tó-dúlő. In: Kozowski JK, Raczky P, editors. The Lengyel, Polgár and Related Cultures in the Middle/Late Neolithic in Central Europe. Krakow: The Polish Academy of Arts and Sciences. p 397-410.

Lichardus J, Lichardus-Itten M. 1996. Spätneolitische Funde von Čičarovce (Ostslowakei) und das obere Theissgebiet an der Schwelle zur frühen Kupferzeit. Sastuma 4/5:144-249.

Lichardus J, Vladár J. 1964. Zu Problemen der Ludanice Gruppe in der Slowakei. Slovenská Archeológia 12: 69-157.

Makkay J. 1982. A magyarországi neolitikum ku- 
tatásának új eredményei (New Issues in Hungarian Neolithic Research). Budapest: Akadémiai Kiadó. $181 \mathrm{p}$.

Makkay J. 1985. Diffusion, antidiffusion and chronology: some general remarks. Acta Archaeologica Academiae Scientiarum Hungaricae 37:3-12.

Makkay J. 2007. The Excavations of the Early Neolithic Sites of the Körös Culture in the Körös Valley, Hungary: The Final Report, Volume I, The Excavations: Stratigraphy, Structures, and Graves. Trieste: Società per la Preistoria e Protostoria della Regione FriuliVenezia Giulia, Quaderno 11.284 p.

Neitzel J, editor. 1999. Great Towns and Regional Polities in the Prehistoric American Southwest and Southeast. Albuquerque: University of New Mexico Press. $325 \mathrm{p}$.

Neustupný E. 1968. Absolute chronology of the Neolithic and Aeneolithic periods in central and south-eastern Europe. Slovenská Archeológia 16:19_ 60.

Neustupný E. 1970. A new epoch in radiocarbon dating. Antiquity 44(173):38-45.

Parkinson WA. 2002. Integration, interaction, and tribal cycling: the transition to the Copper Age on the Great Hungarian Plain. In: Parkinson WA, editor. The Archaeology of Tribal Societies. Ann Arbor: International Monographs in Prehistory 15. p 391-438.

Parkinson WA. 2006a. The Social Organization of Early Copper Age Tribes on the Great Hungarian Plain. BAR International Series 1573. Oxford: Archaeopress. 199 p.

Parkinson WA. 2006b. Tribal boundaries: stylistic variability and social boundary maintenance during the transition to the Copper Age on the Great Hungarian Plain. Journal of Anthropological Archaeology 25: 33-58.

Parkinson WA, Gyucha A, Yerkes RW. 2002. The Neolithic-Copper Age transition on the Great Hungarian Plain: recent excavations at the Tiszapolgár culture settlement of Vésztő-Bikeri. Antiquity 76(293):61920.

Parkinson WA, Yerkes RW, Gyucha A. 2004a. The transition from the Neolithic to the Copper Age: excavations at Vésztô-Bikeri, Hungary, 2000-2002. Journal of Field Archaeology 29:101-21.

Parkinson WA, Gyucha A, Yerkes RW, Sarris A, Hardy M, Morris M. 2004b. Settlement reorganization at the end of the Neolithic in central Europe: recent research in the Körös River Valley, southeastern Hungary. Journal of Eurasian Prehistory 2(2):57-73.

Price TD, editor. 2000. Europe's First Farmers. Cambridge: Cambridge University Press. $416 \mathrm{p}$.

Protsch R, Weninger B. 1984. Frankfort radiocarbon dates I. Radiocarbon 26(2):185-95.

Raczky P. 1988. A Tisza-vidék kulturális és kronológiai kapcsolatai a Balkánnal és az Égeikummal a neolitikum és rézkor idốszakában - Üjabb kutatási eredmények és problémak (Cultural and Chronological
Connections between the Tisza Region and the Balkans and Aegean in the Neolithic and Copper Age Periods: New Research Issues and Problems). SzolnokBudapest: Szolnok County Museums. 79 p.

Raczky P. 1989. Chronological framework of the Early and Middle Neolithic in the Tisza region. Varia Archaeologica Hungarica 2:233-51.

Raczky P. 1992. The Tisza culture of the Great Hungarian Plain. Studia Praehistorica 11-12:162-76.

Raczky P. 1995. New data on the absolute chronology of the Copper Age in the Carpathian Basin. In: Kovács T, editor. Neuere Daten zur Siedlungsgeschichte und Chronologie der Kupferzeit des Karpatbeckens. Budapest: Inventaria Praehistorica Hungariae, Magyar Nemzeti Múzeum. p 51-60.

Raczky P, in press. Archaeological data on space use at a tell-like settlement of the Tisza culture: new results from Öcsöd-Kováshalom, Hungary. Prague: Festschrift for J. Pavuk.

Raczky P, Anders A. 2008. Late Neolithic spatial differentiation at Polgár-Csőszhalom, Eastern Hungary. In: Bailey D, Whittle A, Hofmann D, editors. Living Well Together? Settlement and Materiality in the Neolithic of South-east and Central Europe. Oxford: Oxford University Press. p 35-53.

Raczky P, Domboróczki L, Hajdú Z. 2007. The site of Polgár-Csốszhalom and its cultural and chronological connections with the Lengyel culture. In: Kozowski JK, Raczky P, editors. The Lengyel, Polgár and Related Cultures in the Middle/Late Neolithic in Central Europe. Krakow: The Polish Academy of Arts and Sciences. p 49-70.

Reimer PJ, Baillie MGL, Bard E, Bayliss A, Beck JW, Bertrand CJH, Blackwell PG, Buck CE, Burr GS, Cutler KB, Damon PE, Edwards RL, Fairbanks RG, Friedrich M, Guilderson TP, Hogg AG, Hughen KA, Kromer B, McCormac G, Manning S, Ramsey CB, Reimer RW, Remmele S, Southon JR, Stuiver M, Talamo S, Taylor FW, van der Plicht J, Weyhenmeyer CE. 2004. IntCal04 terrestrial radiocarbon age calibration 0-26 cal kyr BP. Radiocarbon 46(3):1029-58.

Renfrew C. 1970. The tree-ring calibration: an archaeological evaluation. Proceedings of the Prehistoric Society 36:280-311.

Renfrew C. 1973. Before Civilisation. The Radiocarbon Revolution and Prehistoric Europe. London: Penguin Books Ltd. 320 p.

Robb J, Miracle P. 2007. Beyond 'migration' versus 'acculturation': new models for the spread of agriculture. In: Whittle A, Cummings V, editors. Going Over: The Mesolithic-Neolithic Transition in North-west Europe. Proceedings of the British Academy 144. Oxford: Oxford University Press. p 99-116.

Sarris A, Galaty M, Yerkes RW, Parkinson W, Gyucha A, Billingsley D, Tate R. 2004. Geophysical prospection and soil chemistry at the Early Copper Age settlement of Vésztô-Bikeri, southeastern Hungary. Journal of Archaeological Science 31(7):927-39. 
Siklódi Cs. 1983. Kora rézkori település Tiszaföldváron (An Early Copper Age settlement at Tiszaföldvár). A Szolnok Megyei Múzeumok Évkönyve 1982-83:1131.

Šiška S. 1968. Tiszapolgárska kulture na Slovensku (Die Tiszapolgár-Kultur in der Slowakei). Slovenská Archeológia 16:154-75.

Stuiver M, Reimer PJ. 1993. Extended ${ }^{14} \mathrm{C}$ data base and revised CALIB $3.0{ }^{14} \mathrm{C}$ age calibration program. $R a$ diocarbon 35(1):215-30.

Thorpe IJ. 1996. The Origins of Agriculture in Europe. New York: Routledge. 224 p.

Vogel JC, Waterbolk HT. 1963. Groningen radiocarbon dates IV. Radiocarbon 5(1):163-202.

Whittle A. 1996. Europe in the Neolithic: The Creation of New Worlds. Cambridge: Cambridge University Press. 443 p.

Yerkes RW, Sarris A, Frolking T, Parkinson WA, Gyucha A, Hardy M, Catanoso L. 2007. Geophysical and geochemical investigations at two Early Copper Age settlements in the Körös River Valley, southeastern Hungary. Geoarchaeology 22(8):845-71.

Zeidler JA, Buck CE, Litton CD. 1998. The integration of archaeological phase information and radiocarbon results from the Jama River Valley, Ecuador: a Bayesian approach. Latin American Antiquity 9(2):160-79.

\section{APPENDICES}

Appendix 1. Conventional ${ }^{14} \mathrm{C}$ dates from Late Neolithic, Early Copper Age and Middle Copper Age sites on the Great Hungarian Plain. NOTE: dates are listed in descending order from youngest to oldest by site. The conventional dates listed as "unpublished" were compiled by the late Ede Hertelendi of the Institute of Nuclear Research of the Hungarian Academy of Sciences at Debrecen and his colleagues and used in their earlier analyses (Hertelendi and Horváth 1992; Hertelendi et al. 1995; Hertelendi et al. 1998a,b; Horváth and Hertelendi 1994); however, the conventional dates and calibrations were not listed in all of their publications. GrN-1993 from Polgár-Csôszhalom was listed as GrN-1934 by Bognár-Kutzián (1972) and in other publications (see Vogel and Waterbolk 1963:184). Conventional, extended count, and AMS dates shown for Vésztó-Bikeri and Körösladány-Bikeri.

Appendix 1

\begin{tabular}{|c|c|c|c|c|}
\hline Lab nr & Site & Context & ${ }^{14} \mathrm{C}$ age $\mathrm{BP}$ & Reference \\
\hline \multicolumn{5}{|c|}{ Middle Copper Age } \\
\hline \multicolumn{5}{|c|}{ Hunyadihalom culture } \\
\hline GrN-1615 & Tiszalúc-Sarkad & & $4920 \pm 60$ & Forenbaher 1993:238 \\
\hline GrN-1614 & Tiszalúc-Sarkad & & $5020 \pm 40$ & Forenbaher 1993:238 \\
\hline GrN-1613 & Tiszalúc-Sarkad & & $5085 \pm 40$ & Forenbaher 1993:238 \\
\hline GrN-1612 & Tiszalúc-Sarkad & & $5100 \pm 40$ & Forenbaher 1993:238 \\
\hline \multicolumn{5}{|c|}{ Bodrogkeresztúr culture } \\
\hline Deb-441 & $\begin{array}{l}\text { Tiszapolgár-Basat- } \\
\text { anya (Mid-B) }\end{array}$ & Grave 133, Middle B phase & $4090 \pm 180$ & Benkô et al. 1989:1000 \\
\hline Deb-4 & $\begin{array}{l}\text { Tiszapolgár-Basat- } \\
\text { anya (Mid-B) }\end{array}$ & & $4820 \pm 140$ & $\begin{array}{l}\text { Bankoff and Winter } \\
\text { 1990:188 }\end{array}$ \\
\hline Deb-5 & $\begin{array}{l}\text { Tiszapolgár-Basat- } \\
\text { anya (Mid-B) }\end{array}$ & & $4960 \pm 130$ & $\begin{array}{l}\text { Bankoff and Winter } \\
\text { 1990:188 }\end{array}$ \\
\hline Deb-428 & $\begin{array}{l}\text { Tiszapolgár-Basat- } \\
\text { anya (Mid-A) }\end{array}$ & $\begin{array}{l}\text { Grave } 85 \text {, Middle A phase, bone } \\
\text { sample }\end{array}$ & $4240 \pm 180$ & Benkő et al. 1989:1000 \\
\hline Deb-122 & $\begin{array}{l}\text { Tiszapolgár-Basat- } \\
\text { anya (Mid-A) }\end{array}$ & $\begin{array}{l}\text { Grave 101a, Middle A phase, dual } \\
\text { burial, bone }\end{array}$ & $4850 \pm 150$ & Benkő et al. 1989:1000 \\
\hline Deb-214 & $\begin{array}{l}\text { Tiszapolgár-Basat- } \\
\text { anya (Mid-A) }\end{array}$ & $\begin{array}{l}\text { Grave } 44 \text {, Middle A phase, bone } \\
\text { sample }\end{array}$ & $4980 \pm 140$ & Benkő et al. 1989:1000 \\
\hline Deb-350 & $\begin{array}{l}\text { Tiszapolgár-Basat- } \\
\text { anya (Mid-A) }\end{array}$ & $\begin{array}{l}\text { Grave } 41 \text {, Middle A phase, bone } \\
\text { sample }\end{array}$ & $5010 \pm 180$ & Benkő et al. 1989:1000 \\
\hline
\end{tabular}


Appendix 1 (Continued)

\begin{tabular}{|c|c|c|c|c|}
\hline Lab nr & Site & Context & ${ }^{14} \mathrm{C}$ age $\mathrm{BP}$ & Reference \\
\hline Deb-465 & $\begin{array}{l}\text { Tiszapolgár-Basat- } \\
\text { anya (Mid-A) }\end{array}$ & $\begin{array}{l}\text { Grave } 101 \mathrm{~b} \text {, Middle A phase, bone } \\
\text { sample }\end{array}$ & $5020 \pm 170$ & Benkő et al. 1989:1000 \\
\hline Deb-481 & $\begin{array}{l}\text { Tiszapolgár-Basat- } \\
\text { anya (Mid-A) }\end{array}$ & $\begin{array}{l}\text { Grave 59, Middle A phase (above } \\
\text { Grave } 61 \text { ), bone }\end{array}$ & $5210 \pm 170$ & Benkő et al. 1989:1000 \\
\hline Deb-355 & $\begin{array}{l}\text { Tiszapolgár-Basat- } \\
\text { anya (Mid-A) }\end{array}$ & $\begin{array}{l}\text { Grave } 120 \text {, Middle A phase, bone } \\
\text { sample }\end{array}$ & $5220 \pm 190$ & Benkő et al. 1989:1000 \\
\hline
\end{tabular}

Early Copper Age

Tiszapolgár culture

Deb-348 Tiszapolgár-Basatanya (Early)

Deb-349 Tiszapolgár-Basatanya (Early)

Deb-342 Tiszapolgár-Basatanya (Early)

Deb-361 Tiszapolgár-Basatanya (Early)

Deb-464

Tiszapolgár-Basatanya (Early)

Deb-416

Tiszapolgár-Basatanya (Early)

Bln-? Bélmegyer-Mondoki domb

Bln-2165

Méhkerék 23

Beta-162061 Vészt-Mágor

Deb-1936

Tiszapolgár

VERA-3789

HajdúböszörményFicsori-tó-dûllố

VERA-3785 HajdúböszörményFicsori-tó-dúló

VERA-3788 HajdúböszörményFicsori-tó-dûlló

VERA-3787 HajdúböszörményFicsori-tó-dưló

VERA-3786 HajdúböszörményFicsori-tó-dúló

Beta-234313 Körösladány-Bikeri-upper level

Beta-214596 Körösladány-Bikeri-upper level

Beta-234312 Körösladány-Bikeri-upper level

Beta-234306 Körösladány-Bikeri-upper level

Beta-214595 Körösladány-Bikeri-upper level

Beta-234314 Körösladány-Bikeri-upper level

Beta-234307 Körösladány-Bikeri-lower level

Beta-234308 Körösladány-Bikeri-lower level

Beta-234310 Körösladány-Bikeri-older dates

Beta-214597 Körösladány-Bikeri-older dates
Grave 23, Early phase, bone sample

Grave 28, Early phase, bone sample

Grave 54, Early phase, bone sam-

ple

Grave 5, Early phase, bone sample

Grave 61, Early phase, bone sample

Grave 12, Early phase, bone sample

Unit 6-1, bone sample

$?$

Grave, Nr. 57/61, animal bone

Grave, Nr. 30/34, human bone

Grave, Nr. 30/34, animal bone

Grave, Nr. 57/61, human bone

Grave, Nr. 71/75, human bone

F48 well, sample 1 EU7-64

F2 Outer circular ditch bottom fill EU5-53

F35 Bell-shaped pit fill EU6-46

F10 Bell-shaped pit fill EU4-103

F5 west $1 / 2$ Bell-shaped pit (0-10 $\mathrm{cm}) \mathrm{EU} 4-48$

F48 well, sample 2 EU7-64

F28 Bell-shaped pit fill EU4-144

F29 trench in lower occupation level EU4-103

F30 fill (L1) in middle circular ditch EU5-124

F8,9 posthole in Inner circular ditch $5740 \pm 40$ EU5-48
$5020 \pm 180$ Bognár-Kutzián and Csongor 1987

$5060 \pm 170$ Bognár-Kutzián and Csongor 1987

$5090 \pm 190$ Bognár-Kutzián and Csongor 1987

$5350 \pm 190$ Bognár-Kutzián and Csongor 1987

$5460 \pm 170$ Bognár-Kutzián and Csongor 1987

$5600 \pm 180$ Bognár-Kutzián and Csongor 1987

$5300 \pm 70 \quad$ Kalicz and Raczky 1987a:28-9

$5385 \pm 65 \quad$ Kalicz and Raczky 1987a:28-9

$5410 \pm 70 \quad$ Parkinson et al. 2004a: 106

$5450 \pm 40$ may be from Tiszapolgár-Basatanya

$5360 \pm 35$ Kovács and Váczi 2007

$5370 \pm 40 \quad$ Kovács and Váczi 2007

$5370 \pm 45 \quad$ Kovács and Váczi 2007

$5425 \pm 35 \quad$ Kovács and Váczi 2007

$5445 \pm 35$ Kovács and Váczi 2007

$5370 \pm 60$ conventional ${ }^{14} \mathrm{C}$ date

$5370 \pm 40 \quad$ AMS ${ }^{14} \mathrm{C}$ date

$5380 \pm 40 \quad$ AMS ${ }^{14} \mathrm{C}$ date

$5410 \pm 80$ conventional ${ }^{14} \mathrm{C}$ date

$5420 \pm 40 \quad$ AMS ${ }^{14} \mathrm{C}$ date

$5430 \pm 50$ conventional ${ }^{14} \mathrm{C}$ date

$5520 \pm 40 \quad$ AMS ${ }^{14} \mathrm{C}$ date

$5560 \pm 40 \quad$ AMS ${ }^{14} \mathrm{C}$ date

$5730 \pm 40 \quad$ AMS ${ }^{14} \mathrm{C}$ date

AMS ${ }^{14} \mathrm{C}$ date 
Appendix 1 (Continued)

\begin{tabular}{|c|c|c|c|c|}
\hline Lab nr & Site & Context & ${ }^{14} \mathrm{C}$ age $\mathrm{BP}$ & Reference \\
\hline Beta-179782 & $\begin{array}{l}\text { Vésztő-Bikeri- } \\
\text { younger dates }\end{array}$ & $\begin{array}{l}\text { F14 daub/cultural layer above floor } \\
\text { EU2-223 }\end{array}$ & $5310 \pm 50$ & conventional ${ }^{14} \mathrm{C}$ date \\
\hline Beta-162067 & $\begin{array}{l}\text { Vésztô-Bikeri- } \\
\text { younger dates }\end{array}$ & $\begin{array}{l}\text { F4 daub layer above floor level } \\
\text { EU2-27 }\end{array}$ & $5320 \pm 60$ & AMS ${ }^{14} \mathrm{C}$ date \\
\hline Beta-214592 & $\begin{array}{l}\text { Vésztô-Bikeri- } \\
\text { younger dates }\end{array}$ & $\begin{array}{l}\text { F35 kiln/oven in well/cistern EU8- } \\
34\end{array}$ & $5410 \pm 40$ & AMS ${ }^{14} \mathrm{C}$ date \\
\hline Beta-162071 & $\begin{array}{l}\text { Vésztő-Bikeri- } \\
\text { younger dates }\end{array}$ & $\begin{array}{l}\text { Block } 4 \text { midden base of plowzone } \\
\text { EU4-3 }\end{array}$ & $5430 \pm 40$ & AMS ${ }^{14} \mathrm{C}$ date \\
\hline Beta-179793 & $\begin{array}{l}\text { Vésztő-Bikeri-main } \\
\text { occupation }\end{array}$ & $\begin{array}{l}\text { F21 Middle circular ditch fill EU6- } \\
4\end{array}$ & $5420 \pm 50$ & AMS ${ }^{14} \mathrm{C}$ date \\
\hline Beta-179792 & $\begin{array}{l}\text { Vésztô-Bikeri-main } \\
\text { occupation }\end{array}$ & F20 Inner circular ditch fill EU6-6 & $5440 \pm 50$ & AMS ${ }^{14} \mathrm{C}$ date \\
\hline Beta-179787* & $\begin{array}{l}\text { Vésztő-Bikeri-main } \\
\text { occupation }\end{array}$ & $\begin{array}{l}\text { F28 E wall trench F15, W. w.t. F4/ } \\
14 \text { EU2-310 }\end{array}$ & $5440 \pm 140$ & $\begin{array}{l}\text { extended count, con- } \\
\text { ventional date }\end{array}$ \\
\hline Beta-179789 & $\begin{array}{l}\text { Vésztő-Bikeri-main } \\
\text { occupation }\end{array}$ & $\begin{array}{l}\text { F26 house F4/14 N w.t. posthole } \\
\text { EU2-347 }\end{array}$ & $5460 \pm 50$ & AMS ${ }^{14} \mathrm{C}$ date \\
\hline Beta-214593 & $\begin{array}{l}\text { Vésztő-Bikeri-main } \\
\text { occupation }\end{array}$ & F15 North wall trench fill EU9-101 & $5480 \pm 50$ & AMS ${ }^{14} \mathrm{C}$ date \\
\hline Beta-162068 & $\begin{array}{l}\text { Vésztő-Bikeri-main } \\
\text { occupation }\end{array}$ & F4 house floor level EU2-37 & $5480 \pm 40$ & AMS ${ }^{14} \mathrm{C}$ date \\
\hline Beta-162070 & $\begin{array}{l}\text { Vésztő-Bikeri-main } \\
\text { occupation }\end{array}$ & $\begin{array}{l}\text { F5 possible house base of plow- } \\
\text { zone EU3-4 }\end{array}$ & $5490 \pm 50$ & AMS ${ }^{14} \mathrm{C}$ date \\
\hline Beta-179783 & $\begin{array}{l}\text { Vésztő-Bikeri-main } \\
\text { occupation }\end{array}$ & F14 house floor level EU2-234 & $5520 \pm 50$ & conventional ${ }^{14} \mathrm{C}$ date \\
\hline Beta-179788 & $\begin{array}{l}\text { Vésztô-Bikeri-main } \\
\text { occupation }\end{array}$ & $\begin{array}{l}\text { F26 house F4/14 north wall trench } \\
\text { EU2-337 }\end{array}$ & $5540 \pm 40$ & AMS ${ }^{14} \mathrm{C}$ date \\
\hline Beta-179786* & $\begin{array}{l}\text { Vésztó-Bikeri-main } \\
\text { occupation }\end{array}$ & $\begin{array}{l}\text { F28 E wall trench F15, W. w.t. F4/ } \\
14 \text { EU2-284 }\end{array}$ & $5540 \pm 60$ & $\begin{array}{l}\text { extended count, con- } \\
\text { ventional date }\end{array}$ \\
\hline Beta-179790 & $\begin{array}{l}\text { Vésztő-Bikeri-main } \\
\text { occupation }\end{array}$ & F19 Outer circular ditch fill EU5-3 & $5550 \pm 40$ & AMS ${ }^{14} \mathrm{C}$ date \\
\hline Beta-179785 & $\begin{array}{l}\text { Vésztő-Bikeri-main } \\
\text { occupation }\end{array}$ & $\begin{array}{l}\text { F13 Bell pit (yellow clay zone) } \\
\text { EU2-271 }\end{array}$ & $5560 \pm 50$ & AMS ${ }^{14} \mathrm{C}$ date \\
\hline Beta-179784 & $\begin{array}{l}\text { Vésztő-Bikeri-main } \\
\text { occupation }\end{array}$ & $\begin{array}{l}\text { F13 Bell-shaped pit (zone G) EU2- } \\
251\end{array}$ & $5580 \pm 50$ & AMS ${ }^{14} \mathrm{C}$ date \\
\hline Beta-214589 & $\begin{array}{l}\text { Vésztő-Bikeri-main } \\
\text { occupation }\end{array}$ & $\begin{array}{l}\text { F71 burial near r. tibia (charcoal) } \\
\text { EU7-58 }\end{array}$ & $5610 \pm 40$ & AMS ${ }^{14} \mathrm{C}$ date \\
\hline Beta-179791 & $\begin{array}{l}\text { Vésztő-Bikeri-main } \\
\text { occupation }\end{array}$ & $\begin{array}{l}\text { F27 posthole in Inner circular ditch } \\
\text { EU5-6 }\end{array}$ & $5620 \pm 40$ & AMS ${ }^{14} \mathrm{C}$ date \\
\hline Beta-162066 & $\begin{array}{l}\text { Vésztő-Bikeri-older } \\
\text { dates }\end{array}$ & F4 house floor level EU2-18 & $5660 \pm 40$ & AMS ${ }^{14} \mathrm{C}$ date \\
\hline Beta-162065 & $\begin{array}{l}\text { Vésztő-Bikeri-older } \\
\text { dates }\end{array}$ & F2 circular pit fill EU1-13 & $5700 \pm 40$ & AMS ${ }^{14} \mathrm{C}$ date \\
\hline Beta-162069 & $\begin{array}{l}\text { Vésztő-Bikeri-older } \\
\text { dates }\end{array}$ & F4 house floor level EU2-37 & $5790 \pm 100$ & AMS ${ }^{14} \mathrm{C}$ date \\
\hline \multicolumn{5}{|c|}{ Late Neolithic/Prototiszapolgár phase } \\
\hline Deb-1201 & Deszk-Vénó & Pit 3, Square II & $5420 \pm 60$ & $\begin{array}{l}\text { Hertelendi and Horváth } \\
\text { 1992:861-3 }\end{array}$ \\
\hline Bln-2583 & $\begin{array}{l}\text { Berettyóújfalu- } \\
\text { Herpály }\end{array}$ & Levels 6-5 & $5490 \pm 60$ & $\begin{array}{l}\text { Kalicz and Raczky } \\
\text { 1987a:28-9 }\end{array}$ \\
\hline Bln-2493 & $\begin{array}{l}\text { Berettyóújfalu- } \\
\text { Herpály }\end{array}$ & Level 5 & $5645 \pm 55$ & $\begin{array}{l}\text { Kalicz and Raczky } \\
\text { 1987a:28-9 }\end{array}$ \\
\hline Bln-2668 & $\begin{array}{l}\text { Berettyóújfalu- } \\
\text { Herpály }\end{array}$ & Levels 6-5 & $5750 \pm 50$ & $\begin{array}{l}\text { Kalicz and Raczky } \\
\text { 1987a:28-9 }\end{array}$ \\
\hline
\end{tabular}

Late Neolithic

Csốszhalom culture

Deb-417 Bodrogzsadány-

Sq.Ix, pit a, above ashy layer, char- $5400 \pm 180$ Bognár-Kutzián and Akasztószer coal Csongor 1987 
Appendix 1 (Continued)

\begin{tabular}{|c|c|c|c|c|}
\hline Lab nr & Site & Context & ${ }^{14} \mathrm{C}$ age $\mathrm{BP}$ & Reference \\
\hline Deb-357 & $\begin{array}{l}\text { Tiszapolgár-Basat- } \\
\text { anya }\end{array}$ & Grave 84 , bone sample & $5980 \pm 200$ & $\begin{array}{l}\text { Bognár-Kutzián and } \\
\text { Csongor } 1987\end{array}$ \\
\hline Bln-509 & Polgár-Csőszhalom & $\begin{array}{l}\text { House I/A (uppermost level, 0.3- } \\
0.4 \mathrm{~m} \mathrm{bs} \text { ) }\end{array}$ & $5575 \pm 100$ & $\begin{array}{l}\text { Kohl and Quitta 1970: } \\
413\end{array}$ \\
\hline$B \ln -512$ & Polgár-Csôszhalom & $\begin{array}{l}\text { burned floor H. I/F 16a ( } 3.05 \mathrm{~m} \text { bs) } \\
\text { lowest level }\end{array}$ & $5775 \pm 100$ & $\begin{array}{l}\text { Kohl and Quitta 1970: } \\
413\end{array}$ \\
\hline GrN-1993 & Polgár-Csôszhalom & $\begin{array}{l}\text { House I/F, lowest level (charred } \\
\text { grain) }\end{array}$ & $5845 \pm 60$ & $\begin{array}{l}\text { Vogel and Waterbolk } \\
\text { 1963:184 }\end{array}$ \\
\hline Bln-510 & Polgár-Csőszhalom & layer in Sec. I/10 (1.85 m bs) & $5871 \pm 100$ & $\begin{array}{l}\text { Kohl and Quitta 1970: } \\
413\end{array}$ \\
\hline Bln-513 & Polgár-Csőszhalom & $\begin{array}{l}\text { burned House } \mathrm{I} / \mathrm{F} \text { (lowest level, } \\
3.1-3.3 \mathrm{~m} \mathrm{bs} \text { ) }\end{array}$ & $5940 \pm 100$ & $\begin{array}{l}\text { Kohl and Quitta 1970: } \\
413\end{array}$ \\
\hline BM-2321 & Polgár-Csőszhalom & Layer $0.80-1.10 \mathrm{~m}$ deep & $6020 \pm 170$ & Ambers et al. 1987:188 \\
\hline \multicolumn{5}{|c|}{ Herpály culture } \\
\hline$B \ln -2675$ & $\begin{array}{l}\text { Berettyóújfalu- } \\
\text { Szilhalom }\end{array}$ & & $5680 \pm 100$ & $\begin{array}{l}\text { Kalicz and Raczky } \\
\text { 1987a:28-9 }\end{array}$ \\
\hline Bln-1679 & Esztár-Fenyvespart & & $5770 \pm 55$ & $\begin{array}{l}\text { Kalicz and Raczky } \\
\text { 1987a:28-9 }\end{array}$ \\
\hline Bln-2958 & $\begin{array}{l}\text { Berettyóújfalu- } \\
\text { Herpály }\end{array}$ & Level 6 & $5630 \pm 60$ & $\begin{array}{l}\text { Kalicz and Raczky } \\
\text { 1987a:28-9 }\end{array}$ \\
\hline Bln-2494 & $\begin{array}{l}\text { Berettyóújfalu- } \\
\text { Herpály }\end{array}$ & Level 6 & $5655 \pm 50$ & $\begin{array}{l}\text { Kalicz and Raczky } \\
\text { 1987a:28-9 }\end{array}$ \\
\hline Bln-2923 & $\begin{array}{l}\text { Berettyóújfalu- } \\
\text { Herpály }\end{array}$ & Level 6 & $5680 \pm 80$ & $\begin{array}{l}\text { Kalicz and Raczky } \\
\text { 1987a:28-9 }\end{array}$ \\
\hline Bln-2584 & $\begin{array}{l}\text { Berettyóújfalu- } \\
\text { Herpály }\end{array}$ & Level 6 & $5760 \pm 60$ & $\begin{array}{l}\text { Kalicz and Raczky } \\
\text { 1987a:28-9 }\end{array}$ \\
\hline Bln-2670 & $\begin{array}{l}\text { Berettyóújfalu- } \\
\text { Herpály }\end{array}$ & Level 6 & $5810 \pm 50$ & $\begin{array}{l}\text { Kalicz and Raczky } \\
\text { 1987a:28-9 }\end{array}$ \\
\hline Bln-2931 & $\begin{array}{l}\text { Berettyóújfalu- } \\
\text { Herpály }\end{array}$ & Level 7 & $5500 \pm 60$ & $\begin{array}{l}\text { Kalicz and Raczky } \\
\text { 1987a:28-9 }\end{array}$ \\
\hline Bln-2993 & $\begin{array}{l}\text { Berettyóújfalu- } \\
\text { Herpály }\end{array}$ & Level 7 & $5520 \pm 70$ & $\begin{array}{l}\text { Kalicz and Raczky } \\
\text { 1987a:28-9 }\end{array}$ \\
\hline Bln-2706 & $\begin{array}{l}\text { Berettyóújfalu- } \\
\text { Herpály }\end{array}$ & Level 7 & $5706 \pm 60$ & $\begin{array}{l}\text { Kalicz and Raczky } \\
\text { 1987a:28-9 }\end{array}$ \\
\hline Bln-2937 & $\begin{array}{l}\text { Berettyóújfalu- } \\
\text { Herpály }\end{array}$ & Level 7 & $5770 \pm 70$ & $\begin{array}{l}\text { Kalicz and Raczky } \\
\text { 1987a:28-9 }\end{array}$ \\
\hline Bln-2924 & $\begin{array}{l}\text { Berettyóújfalu- } \\
\text { Herpály }\end{array}$ & Level 7 & $5820 \pm 70$ & $\begin{array}{l}\text { Kalicz and Raczky } \\
\text { 1987a:28-9 }\end{array}$ \\
\hline Bln-2938 & $\begin{array}{l}\text { Berettyóújfalu- } \\
\text { Herpály }\end{array}$ & Levels 8-7 & $5600 \pm 60$ & $\begin{array}{l}\text { Kalicz and Raczky } \\
\text { 1987a:28-9 }\end{array}$ \\
\hline Bln-2926 & $\begin{array}{l}\text { Berettyóújfalu- } \\
\text { Herpály }\end{array}$ & Levels 8-7 & $5770 \pm 80$ & $\begin{array}{l}\text { Kalicz and Raczky } \\
\text { 1987a:28-9 }\end{array}$ \\
\hline Bln-2929 & $\begin{array}{l}\text { Berettyóújfalu- } \\
\text { Herpály }\end{array}$ & Levels 8-7 & $5800 \pm 70$ & $\begin{array}{l}\text { Kalicz and Raczky } \\
\text { 1987a:28-9 }\end{array}$ \\
\hline Bln-2925 & $\begin{array}{l}\text { Berettyóújfalu- } \\
\text { Herpály }\end{array}$ & Levels 8-7 & $5830 \pm 70$ & $\begin{array}{l}\text { Kalicz and Raczky } \\
\text { 1987a:28-9 }\end{array}$ \\
\hline Bln-2673 & $\begin{array}{l}\text { Berettyóújfalu- } \\
\text { Herpály }\end{array}$ & Level 8 & $5630 \pm 70$ & $\begin{array}{l}\text { Kalicz and Raczky } \\
\text { 1987a:28-9 }\end{array}$ \\
\hline Bln-2939 & $\begin{array}{l}\text { Berettyóújfalu- } \\
\text { Herpály }\end{array}$ & Level 8 & $5680 \pm 60$ & $\begin{array}{l}\text { Kalicz and Raczky } \\
\text { 1987a:28-9 }\end{array}$ \\
\hline Bln-2927 & $\begin{array}{l}\text { Berettyóújfalu- } \\
\text { Herpály }\end{array}$ & Level 8 & $5710 \pm 80$ & $\begin{array}{l}\text { Kalicz and Raczky } \\
\text { 1987a:28-9 }\end{array}$ \\
\hline Bln-2930 & $\begin{array}{l}\text { Berettyóújfalu- } \\
\text { Herpály }\end{array}$ & Level 8 & $5710 \pm 60$ & $\begin{array}{l}\text { Kalicz and Raczky } \\
\text { 1987a:28-9 }\end{array}$ \\
\hline Bln-2932 & $\begin{array}{l}\text { Berettyóújfalu- } \\
\text { Herpály }\end{array}$ & Level 8 & $5730 \pm 70$ & $\begin{array}{l}\text { Kalicz and Raczky } \\
1987 \mathrm{a}: 28-9\end{array}$ \\
\hline
\end{tabular}


Appendix 1 (Continued)

\begin{tabular}{|c|c|c|c|c|}
\hline Lab nr & Site & Context & ${ }^{14} \mathrm{C}$ age $\mathrm{BP}$ & Reference \\
\hline Bln-2933 & $\begin{array}{l}\text { Berettyóújfalu- } \\
\text { Herpály }\end{array}$ & Level 8 & $5830 \pm 80$ & $\begin{array}{l}\text { Kalicz and Raczky } \\
\text { 1987a:28-9 }\end{array}$ \\
\hline Bln-2940 & $\begin{array}{l}\text { Berettyóújfalu- } \\
\text { Herpály }\end{array}$ & Level 8 & $5840 \pm 60$ & $\begin{array}{l}\text { Kalicz and Raczky } \\
\text { 1987a:28-9 }\end{array}$ \\
\hline$B \ln -2928$ & $\begin{array}{l}\text { Berettyóújfalu- } \\
\text { Herpály }\end{array}$ & Level 8 & $5840 \pm 70$ & $\begin{array}{l}\text { Kalicz and Raczky } \\
\text { 1987a:28-9 }\end{array}$ \\
\hline Bln-2934 & $\begin{array}{l}\text { Berettyóújfalu- } \\
\text { Herpály }\end{array}$ & Level 9 & $5730 \pm 80$ & $\begin{array}{l}\text { Kalicz and Raczky } \\
\text { 1987a:28-9 }\end{array}$ \\
\hline Bln-2935 & $\begin{array}{l}\text { Berettyóújfalu- } \\
\text { Herpály }\end{array}$ & Level 9 & $5790 \pm 60$ & $\begin{array}{l}\text { Kalicz and Raczky } \\
\text { 1987a:28-9 }\end{array}$ \\
\hline Bln-2936 & $\begin{array}{l}\text { Berettyóújfalu- } \\
\text { Herpály }\end{array}$ & Level 9 & $5930 \pm 60$ & $\begin{array}{l}\text { Kalicz and Raczky } \\
\text { 1987a:28-9 }\end{array}$ \\
\hline \multicolumn{5}{|l|}{ Tisza culture } \\
\hline Bln-1934 & Deszk-Ordos & & $5595 \pm 100$ & $\begin{array}{l}\text { Kalicz and Raczky } \\
\text { 1987a:28-9 }\end{array}$ \\
\hline$B \ln -515$ & Kisköre-Gát & $\begin{array}{l}\text { oak charcoal in fireplace in pit } \\
\text { (XVII,6) } 1.6 \mathrm{~m}\end{array}$ & $5890 \pm 120$ & $\begin{array}{l}\text { Kohl and Quitta 1970: } \\
410\end{array}$ \\
\hline Bln-179 & Kisköre-Gát & $\begin{array}{l}\text { organic temper sherds } 0.8-1.6 \mathrm{~m} \text { bs } \\
\text { (XVII,6) }\end{array}$ & $5995 \pm 80$ & $\begin{array}{l}\text { Kohl and Quitta 1970: } \\
410\end{array}$ \\
\hline Deb-1389 & $\begin{array}{l}\text { Hódmezővásárhely- } \\
\text { Gorzsa }\end{array}$ & Square IX, Level 2 & $5570 \pm 60$ & $\begin{array}{l}\text { Hertelendi and Horváth } \\
\text { 1992:861-3 }\end{array}$ \\
\hline $\mathrm{B} \ln ?$ & $\begin{array}{l}\text { Hódmezővásárhely- } \\
\text { Gorzsa }\end{array}$ & $?$ & $5580 \pm 100$ & $\begin{array}{l}\text { Kalicz and Raczky } \\
\text { 1987a:28-9 }\end{array}$ \\
\hline Z-2009 & $\begin{array}{l}\text { Hódmezôvásárhely- } \\
\text { Gorzsa }\end{array}$ & $\mathrm{C}$ & $5610 \pm 110$ & Benkő et al. 1989:1000 \\
\hline Bln-3109 & $\begin{array}{l}\text { Hódmezővásárhely- } \\
\text { Gorzsa }\end{array}$ & $\mathrm{C}$ & $5640 \pm 60$ & Benkő et al. 1989:1000 \\
\hline Fra-76 & $\begin{array}{l}\text { Hódmezővásárhely- } \\
\text { Gorzsa }\end{array}$ & $\begin{array}{l}\text { House } 2 \text { (burned), Blk III, L.10, } \\
2.0 \text { m depth }\end{array}$ & $5650 \pm 110$ & $\begin{array}{l}\text { Protsch and Weninger } \\
\text { 1984:191-2 }\end{array}$ \\
\hline Fra-77 & $\begin{array}{l}\text { Hódmezôvásárhely- } \\
\text { Gorzsa }\end{array}$ & $\begin{array}{l}\text { House } 2 \text { (burned), Blk III, L.10, } \\
2.1 \mathrm{~m} \text { depth }\end{array}$ & $5670 \pm 100$ & $\begin{array}{l}\text { Protsch and Weninger } \\
1984: 191-2\end{array}$ \\
\hline Deb-1238 & $\begin{array}{l}\text { Hódmezővásárhely- } \\
\text { Gorzsa }\end{array}$ & Square XI, Level 10 & $5750 \pm 60$ & $\begin{array}{l}\text { Hertelendi and Horváth } \\
\text { 1992:861-3 }\end{array}$ \\
\hline Deb-1175 & $\begin{array}{l}\text { Hódmezôvásárhely- } \\
\text { Gorzsa }\end{array}$ & Sq.VIII, Levels 16-17b & $5760 \pm 60$ & $\begin{array}{l}\text { Hertelendi and Horváth } \\
\text { 1992:861-3 }\end{array}$ \\
\hline Deb-1171 & $\begin{array}{l}\text { Hódmezővásárhely- } \\
\text { Gorzsa }\end{array}$ & Square VI, Level 10 & $5760 \pm 60$ & $\begin{array}{l}\text { Hertelendi and Horváth } \\
\text { 1992:861-3 }\end{array}$ \\
\hline Deb-1384 & $\begin{array}{l}\text { Hódmezővásárhely- } \\
\text { Gorzsa }\end{array}$ & Sq.VIII, Level 17c-e & $5780 \pm 60$ & $\begin{array}{l}\text { Hertelendi and Horváth } \\
\text { 1992:861-3 }\end{array}$ \\
\hline Deb-1413 & $\begin{array}{l}\text { Hódmezővásárhely- } \\
\text { Gorzsa }\end{array}$ & Grave 16 , Square $X$ & $5790 \pm 60$ & $\begin{array}{l}\text { Hertelendi and Horváth } \\
\text { 1992:861-3 }\end{array}$ \\
\hline Z-2010 & $\begin{array}{l}\text { Hódmezővásárhely- } \\
\text { Gorzsa }\end{array}$ & $\mathrm{C} 1$ & $5820 \pm 110$ & Benkő et al. 1989:1000 \\
\hline Deb-1354 & $\begin{array}{l}\text { Hódmezővásárhely- } \\
\text { Gorzsa }\end{array}$ & Grave 16 , Square $X$ & $5830 \pm 60$ & $\begin{array}{l}\text { Hertelendi and Horváth } \\
\text { 1992:861-3 }\end{array}$ \\
\hline Deb-1386 & $\begin{array}{l}\text { Hódmezővásárhely- } \\
\text { Gorzsa }\end{array}$ & Sq.VIII, Lev. 16-17b & $5840 \pm 60$ & $\begin{array}{l}\text { Hertelendi and Horváth } \\
\text { 1992:861-3 }\end{array}$ \\
\hline Deb-1172 & $\begin{array}{l}\text { Hódmezővásárhely- } \\
\text { Gorzsa }\end{array}$ & Sq.VIII, Lev. 12-13 & $5850 \pm 60$ & $\begin{array}{l}\text { Hertelendi and Horváth } \\
\text { 1992:861-3 }\end{array}$ \\
\hline Deb-1174 & $\begin{array}{l}\text { Hódmezôvásárhely- } \\
\text { Gorzsa }\end{array}$ & Sq.VIII, L.17c-e & $5860 \pm 60$ & $\begin{array}{l}\text { Hertelendi and Horváth } \\
\text { 1992:861-3 }\end{array}$ \\
\hline Deb-1173 & $\begin{array}{l}\text { Hódmezővásárhely- } \\
\text { Gorzsa }\end{array}$ & Sq.XI, L.10, Ditch 1 & $5880 \pm 60$ & $\begin{array}{l}\text { Hertelendi and Horváth } \\
\text { 1992:861-3 }\end{array}$ \\
\hline Z-2011 & $\begin{array}{l}\text { Hódmezővásárhely- } \\
\text { Gorzsa }\end{array}$ & $\mathrm{D}$ & $5890 \pm 110$ & Benkő et al. 1989:1000 \\
\hline Deb-1387 & $\begin{array}{l}\text { Hódmezővásárhely- } \\
\text { Gorzsa }\end{array}$ & Sq.XI, L.10, Ditch 1 & $5900 \pm 60$ & $\begin{array}{l}\text { Hertelendi and Horváth } \\
\text { 1992:861-3 }\end{array}$ \\
\hline
\end{tabular}


Appendix 1 (Continued)

\begin{tabular}{|c|c|c|c|c|}
\hline Lab nr & Site & Context & ${ }^{14} \mathrm{C}$ age $\mathrm{BP}$ & Reference \\
\hline Deb-1240 & $\begin{array}{l}\text { Hódmezővásárhely- } \\
\text { Gorzsa }\end{array}$ & Grave 42, Sq. IX & $5900 \pm 60$ & $\begin{array}{l}\text { Hertelendi and Horváth } \\
\text { 1992:861-3 }\end{array}$ \\
\hline Fra-114 & $\begin{array}{l}\text { Hódmezővásárhely- } \\
\text { Gorzsa }\end{array}$ & $\mathrm{C} 1$ & $5910 \pm 100$ & Benkő et al. 1989:1000 \\
\hline Deb-1191 & $\begin{array}{l}\text { Hódmezővásárhely- } \\
\text { Gorzsa }\end{array}$ & Sq. XVIII, L.24-25 & $5910 \pm 60$ & $\begin{array}{l}\text { Hertelendi and Horváth } \\
\text { 1992:861-3 }\end{array}$ \\
\hline Fra-108 & $\begin{array}{l}\text { Hódmezővásárhely- } \\
\text { Gorzsa }\end{array}$ & $\begin{array}{l}\text { Pits } 2 \text { and 3, Level } 16 \text { (earliest } \\
\text { level) }\end{array}$ & $5970 \pm 100$ & $\begin{array}{l}\text { Protsch and Weninger } \\
1984: 191-2\end{array}$ \\
\hline Fra-95 & $\begin{array}{l}\text { Hódmezővásárhely- } \\
\text { Gorzsa }\end{array}$ & $\begin{array}{l}\text { Block III/b, Level 1, } 1.15 \mathrm{~m} \text { depth } \\
\text { with } 3 \text { pots }\end{array}$ & $5970 \pm 100$ & $\begin{array}{l}\text { Protsch and Weninger } \\
1984: 191-2\end{array}$ \\
\hline Deb-1187 & $\begin{array}{l}\text { Hódmezővásárhely- } \\
\text { Gorzsa }\end{array}$ & Grave 42 , Sq. IX & $5990 \pm 60$ & $\begin{array}{l}\text { Hertelendi and Horváth } \\
\text { 1992:861-3 }\end{array}$ \\
\hline Deb-1202 & $\begin{array}{l}\text { Hódmezővásárhely- } \\
\text { Gorzsa }\end{array}$ & Grave 42 , Sq. IX & $6050 \pm 60$ & $\begin{array}{l}\text { Hertelendi and Horváth } \\
\text { 1992:861-3 }\end{array}$ \\
\hline \multicolumn{5}{|l|}{ Early Tisza } \\
\hline Deb-1222 & $\begin{array}{l}\text { Hódmezővásárhely- } \\
\text { Kökénydomb }\end{array}$ & House 1, Level 3 & $5800 \pm 60$ & $\begin{array}{l}\text { Hertelendi and Horváth } \\
\text { 1992:861-3 }\end{array}$ \\
\hline Deb-1411 & $\begin{array}{l}\text { Hódmezővásárhely- } \\
\text { Kökénydomb }\end{array}$ & House 1, Level 3 & $5850 \pm 60$ & $\begin{array}{l}\text { Hertelendi and Horváth } \\
\text { 1992:861-3 }\end{array}$ \\
\hline Deb-1255 & $\begin{array}{l}\text { Hódmezővásárhely- } \\
\text { Kökénydomb }\end{array}$ & House 1, Level 3 & $5890 \pm 60$ & $\begin{array}{l}\text { Hertelendi and Horváth } \\
\text { 1992:861-3 }\end{array}$ \\
\hline Deb-1364 & $\begin{array}{l}\text { Hódmezővásárhely- } \\
\text { Kökénydomb }\end{array}$ & Levels 3-4 & $5870 \pm 60$ & $\begin{array}{l}\text { Hertelendi and Horváth } \\
\text { 1992:861-3 }\end{array}$ \\
\hline Deb-1513 & $\begin{array}{l}\text { Hódmezővásárhely- } \\
\text { Kökénydomb }\end{array}$ & Levels 3-5 & $5900 \pm 60$ & $\begin{array}{l}\text { Hertelendi and Horváth } \\
\text { 1992:861-3 }\end{array}$ \\
\hline Deb-1367 & $\begin{array}{l}\text { Hódmezővásárhely- } \\
\text { Kökénydomb }\end{array}$ & Pit 2 & $5970 \pm 60$ & $\begin{array}{l}\text { Hertelendi and Horváth } \\
\text { 1992:861-3 }\end{array}$ \\
\hline Deb-1388 & $\begin{array}{l}\text { Hódmezővásárhely- } \\
\text { Kökénydomb }\end{array}$ & House 1, Level 3 & $6090 \pm 60$ & $\begin{array}{l}\text { Hertelendi and Horváth } \\
\text { 1992:861-3 }\end{array}$ \\
\hline Deb-1412 & $\begin{array}{l}\text { Hódmezővásárhely- } \\
\text { Kökénydomb }\end{array}$ & Level 6 & $6100 \pm 60$ & $\begin{array}{l}\text { Hertelendi and Horváth } \\
\text { 1992:861-3 }\end{array}$ \\
\hline Deb-1365 & $\begin{array}{l}\text { Hódmezővásárhely- } \\
\text { Kökénydomb }\end{array}$ & Pit 1 & $6150 \pm 60$ & $\begin{array}{l}\text { Hertelendi and Horváth } \\
\text { 1992:861-3 }\end{array}$ \\
\hline Deb-1263 & $\begin{array}{l}\text { Hódmezővásárhely- } \\
\text { Kökénydomb }\end{array}$ & House 1, Level 3 & $6190 \pm 60$ & $\begin{array}{l}\text { Hertelendi and Horváth } \\
\text { 1992:861-3 }\end{array}$ \\
\hline Deb-1221 & Szegvár-Tűzköves & Pit 93, Level 20 & $5800 \pm 60$ & $\begin{array}{l}\text { Hertelendi and Horváth } \\
\text { 1992:861-3 }\end{array}$ \\
\hline Deb-1355 & Szegvár-Tűzköves & Grave 1, Levels 10-12 & $5830 \pm 60$ & $\begin{array}{l}\text { Hertelendi and Horváth } \\
\text { 1992:861-3 }\end{array}$ \\
\hline Deb-1256 & Szegvár-Tűzköves & Levels 19-20 & $6010 \pm 60$ & $\begin{array}{l}\text { Hertelendi and Horváth } \\
\text { 1992:861-3 }\end{array}$ \\
\hline Deb-1229 & Szegvár-Tűzköves & Levels 26-27 & $6050 \pm 60$ & $\begin{array}{l}\text { Hertelendi and Horváth } \\
\text { 1992:861-3 }\end{array}$ \\
\hline Deb-1420 & Szegvár-Túzköves & Pit 105, Level 29 & $6100 \pm 60$ & $\begin{array}{l}\text { Hertelendi and Horváth } \\
\text { 1992:861-3 }\end{array}$ \\
\hline BM-2323 & Szegvár-Túzköves & $\begin{array}{l}\text { Pit in Tisza Layer over MN Szakal- } \\
\text { hát material }\end{array}$ & $6120 \pm 40$ & Ambers et al. 1987:188 \\
\hline Deb-1254 & Szegvár-Túzköves & Levels $23-24$ & $6210 \pm 60$ & $\begin{array}{l}\text { Hertelendi and Horváth } \\
\text { 1992:861-3 }\end{array}$ \\
\hline BM-2322 & Szegvár-Túzköves & $\begin{array}{l}\text { Pit in Tisza Layer over MN Szakal- } \\
\text { hát material }\end{array}$ & $6250 \pm 190$ & Ambers et al. 1987:188 \\
\hline Bln-1342 & Vésztő-Mágor & Level 3 & $5970 \pm 80$ & $\begin{array}{l}\text { Kalicz and Raczky } \\
1987 \mathrm{a}: 28-9\end{array}$ \\
\hline Bln-1626 & Vésztő-Mágor & House in Level 4 & $6000 \pm 60$ & $\begin{array}{l}\text { Kalicz and Raczky } \\
1987 \mathrm{a}: 28-9\end{array}$ \\
\hline Bln-1625 & Vésztő-Mágor & House in Level 3 & $6150 \pm 60$ & $\begin{array}{l}\text { Kalicz and Raczky } \\
\text { 1987a:28-9 }\end{array}$ \\
\hline
\end{tabular}


Appendix 1 (Continued)

\begin{tabular}{|c|c|c|c|c|}
\hline Lab nr & Site & Context & ${ }^{14} \mathrm{C}$ age $\mathrm{BP}$ & Reference \\
\hline Bln-1628 & Vésztő-Mágor & House in Level 3 & $6250 \pm 60$ & $\begin{array}{l}\text { Kalicz and Raczky } \\
\text { 1987a:28-9 }\end{array}$ \\
\hline Deb-1186 & Tápé-Lebő-A & Levels 1-2 & $5860 \pm 60$ & $\begin{array}{l}\text { Hertelendi and Horváth } \\
\text { 1992:861-3 }\end{array}$ \\
\hline Z-2007 & Tápé-Lebő-A & $?$ & $5870 \pm 110$ & Benkő et al. 1989:1000 \\
\hline Deb-1211 & Tápé-Lebő-A & Level 8 & $5900 \pm 60$ & $\begin{array}{l}\text { Hertelendi and Horváth } \\
\text { 1992:861-3 }\end{array}$ \\
\hline Deb-1356 & Tápé-Lebő-A & Ditch 14, Level 16 & $5950 \pm 60$ & $\begin{array}{l}\text { Hertelendi and Horváth } \\
\text { 1992:861-3 }\end{array}$ \\
\hline Deb-1363 & Tápé-Lebő-A & Ditch 14, Level 16 & $6050 \pm 60$ & $\begin{array}{l}\text { Hertelendi and Horváth } \\
\text { 1992:861-3 }\end{array}$ \\
\hline Deb-1176 & Tápé-Lebő-A & Levels 5-6 & $6060 \pm 60$ & $\begin{array}{l}\text { Hertelendi and Horváth } \\
\text { 1992:861-3 }\end{array}$ \\
\hline Deb-1264 & Tápé-Lebő-A & Levels 12-13 & $6100 \pm 60$ & $\begin{array}{l}\text { Hertelendi and Horváth } \\
\text { 1992:861-3 }\end{array}$ \\
\hline Deb-1196 & Tápé-Lebő-A & Pit 24, Level 6 & $6130 \pm 60$ & $\begin{array}{l}\text { Hertelendi and Horváth } \\
\text { 1992:861-3 }\end{array}$ \\
\hline Deb-1267 & Tápé-Lebố-A & Pit 41, Level 14 & $6150 \pm 60$ & $\begin{array}{l}\text { Hertelendi and Horváth } \\
\text { 1992:861-3 }\end{array}$ \\
\hline Deb-1188 & Tápé-Lebő-A & Level 10 & $6160 \pm 60$ & $\begin{array}{l}\text { Hertelendi and Horváth } \\
\text { 1992:861-3 }\end{array}$ \\
\hline Deb-1265 & Tápé-Lebő-A & Pit 37, Level 12 & $6170 \pm 60$ & $\begin{array}{l}\text { Hertelendi and Horváth } \\
\text { 1992:861-3 }\end{array}$ \\
\hline Deb-1200 & Tápé-Lebő-A & Pit 35, Level 12 & $6170 \pm 60$ & $\begin{array}{l}\text { Hertelendi and Horváth } \\
\text { 1992:861-3 }\end{array}$ \\
\hline Deb-1197 & Tápé-Lebő-A & Pit 32, Level 12 & $6200 \pm 60$ & $\begin{array}{l}\text { Hertelendi and Horváth } \\
\text { 1992:861-3 }\end{array}$ \\
\hline Deb-1195 & Tápé-Lebő-A & Levels 14-15 & $6210 \pm 60$ & $\begin{array}{l}\text { Hertelendi and Horváth } \\
\text { 1992:861-3 }\end{array}$ \\
\hline Deb-1189 & Tápé-Lebő-A & Levels 12-14 & $6230 \pm 60$ & $\begin{array}{l}\text { Hertelendi and Horváth } \\
\text { 1992:861-3 }\end{array}$ \\
\hline Deb-1366 & Tápé-Lebő-A & Pit 53, Level 16 & $6290 \pm 60$ & $\begin{array}{l}\text { Hertelendi and Horváth } \\
\text { 1992:861-3 }\end{array}$ \\
\hline Deb-1643 & Tápé-Lebő-A & Fea. 39, Level 17(12) charcoal & $6370 \pm 60$ & unpublished \\
\hline
\end{tabular}

Appendix 2. Calibrated ${ }^{14} \mathrm{C}$ dates from Late Neolithic, Early Copper Age, and Middle Copper Age sites on the Great Hungarian Plain listed by lab number. NOTE: 1- and 2- $\sigma$ calibration ranges using CALIB Rev 5.01 and the IntCal04 calibration curve are shown. Staring and ending time ranges cal $\mathrm{BC}$ are given followed by the relative area under the calibration curve.

Appendix 2

\begin{tabular}{|c|c|c|c|}
\hline Lab nr & & $1-\sigma$ calib. range $\mathrm{BP}$ & $2-\sigma$ calib. range $\mathrm{BP}$ \\
\hline \multicolumn{4}{|c|}{ Middle Copper Age } \\
\hline \multicolumn{4}{|c|}{ Hunyadihalom culture, Tiszalúc-Sarkad site } \\
\hline GrN-1615 & Tiszalúc-Sarkad & $\begin{array}{l}3763-3724(0.30) \\
3715-3647(0.70)\end{array}$ & $\begin{array}{l}3934-3875(0.06) \\
3806-3632(0.92) \\
3558-3538(0.02)\end{array}$ \\
\hline GrN-1614 & Tiszalúc-Sarkad & $\begin{array}{l}3936-3872(0.49) \\
3806-3760(0.39) \\
3741-3731(0.05) \\
3725-3714(0.70)\end{array}$ & $\begin{array}{l}3944-3853(0.44) \\
3849-3709(0.56)\end{array}$ \\
\hline
\end{tabular}


Appendix 2 (Continued)

\begin{tabular}{|c|c|c|c|}
\hline \multicolumn{2}{|l|}{ Lab nr } & \multirow{2}{*}{$\begin{array}{l}1-\sigma \text { calib. range BP } \\
\text { 3956-3927(0.26); } \\
3918-3915(0.02) ; \\
3877-3804(0.72)\end{array}$} & \multirow{2}{*}{$\frac{2-\sigma \text { calib. range BP }}{3967-3791(1.0)}$} \\
\hline GrN-1613 & Tiszalúc-Sarkad & & \\
\hline GrN-1612 & Tiszalúc-Sarkad & $\begin{array}{l}\text { 3962-3933(0.31); } \\
\text { 3875-3806(0.69) }\end{array}$ & $3972-3797(1.0)$ \\
\hline Summed probabilities & Tiszalúc-Sarkad all 4 dates & 3958-3796(1.0) & 3964-3653(1.0) \\
\hline \multicolumn{4}{|c|}{ Bodrogkeresztúr culture, Tiszapolgár-Basatanya cemetery (Middle B phase) } \\
\hline Deb-441 & Grave 133 , Middle B phase & $\begin{array}{l}2899-2457(0.97) ; \\
2418-2407(0.01) ; \\
2375-2367(0.01) ; \\
2361-2352(0.01)\end{array}$ & $\begin{array}{l}3264-3242(<0.01) \\
3103-2130(0.99) \\
2086-2050(0.01)\end{array}$ \\
\hline Deb-4 & & $\begin{array}{l}3760-3741(0.04) \\
3729-3726(0.01) \\
3714-3497(0.74) \\
3456-3377(0.21)\end{array}$ & $\begin{array}{l}3959-3333(0.98) \\
3213-3188(0.01) \\
3154-3132(0.01)\end{array}$ \\
\hline Deb-5 & & $\begin{array}{l}3941-3857(0.28) \\
3842-3839(0.01) \\
3819-3641(0.71)\end{array}$ & $\begin{array}{l}4039-4017(0.01) \\
3999-3506(0.97) \\
3427-3381(0.02)\end{array}$ \\
\hline Summed probabilities & Tiszapolgár-Basatanya Middle B & $\begin{array}{l}\text { 3958-3493(0.79); } \\
3466-3374(0.09) \\
2847-2842(<0.01)\end{array}$ & $\begin{array}{l}4039-4012(<0.01) \\
4001-3330(0.67) ; \\
3213-3185(<0.01)\end{array}$ \\
\hline & all 3 dates combined & $\begin{array}{l}2840-2812(0.02) ; \\
2737-3731(0.01) ; \\
2691-2688(<0.01) \\
2677-2572(0.08)\end{array}$ & $\begin{array}{l}3155-3126(<0.01) \\
3083-3064(<0.01) \\
3027-2199(0.32) \\
2155(<0.01)\end{array}$ \\
\hline \multicolumn{4}{|c|}{ Bodrogkeresztúr culture, Tiszapolgár-Basatanya cemetery (Middle A phase, bone samples) } \\
\hline Deb-428 & Grave 85 & $3090-2573(1.0)$ & $\begin{array}{l}3365-2397(0.99) \\
2384-2346(0.01)\end{array}$ \\
\hline Deb-122 & Grave 101a & $\begin{array}{l}3794-3499(0.88) \\
3432-3379(0.12)\end{array}$ & $\begin{array}{l}3979-3332(0.99) ; \\
3213-3188(<0.01) \\
3155-3131(<0.01)\end{array}$ \\
\hline Deb-214 & Grave 44 & $\begin{array}{l}3943-3854(0.30) \\
3847-3830(0.06) \\
3825-3652(0.64)\end{array}$ & $\begin{array}{l}4218-4214(<0.01) \\
4148-4135(<0.01) \\
4054-3498(0.97) \\
3437-3378(0.02)\end{array}$ \\
\hline Deb-350 & Grave 41 & $\begin{array}{l}4037-4021(0.02) \\
3994-3635(0.98)\end{array}$ & $\begin{array}{l}4236-3496(0.96) \\
3460-3376(0.04)\end{array}$ \\
\hline Deb-465 & Grave $101 \mathrm{~b}$ & $3986-3640(1.0)$ & $\begin{array}{l}4235-3501(0.98) \\
3429-3380(0.02)\end{array}$ \\
\hline Deb-481 & Grave 59 (above Grave 61) & $\begin{array}{l}4239-3926(0.82) \\
3920-3914(0.02) \\
3877-3804(0.16)\end{array}$ & $4351-3660(1.0)$ \\
\hline Deb-355 & Grave 120 & $\begin{array}{l}4259-3910(0.84) \\
3878-3802(0.16)\end{array}$ & $\begin{array}{l}4446-4419(0.01) \\
4399-4381(0.01) \\
4374-3646(0.98)\end{array}$ \\
\hline Summed probabilities & Tiszapolgár-Basatanya Middle A & $\begin{array}{l}4227-4199(0.03) \\
4169-4126(0.04) \\
4120-4090(0.03)\end{array}$ & $\begin{array}{l}\text { 4357-3341 }(0.88) \\
3315-3291(<0.01) \\
3289-3272(<0.01)\end{array}$ \\
\hline & all 7 dates combined & $\begin{array}{l}\text { 4079-3627(0.84); } \\
3586-3528(0.06)\end{array}$ & $\begin{array}{l}3265-3236(<0.01) \\
3169-3162(<0.01) \\
3111-2568(0.11) ; \\
2514-2499(<0.01)\end{array}$ \\
\hline \multicolumn{2}{|c|}{ Summed probabilities, Middle Copper Age } & $\begin{array}{l}\text { 4037-4019(0.01); } \\
\text { 3995-3263(0.91); } \\
\text { 3602-3523(0.08) }\end{array}$ & $\begin{array}{l}4347-3336(0.88) \\
3260-3258(<0.01) \\
3207-3192(<0.01) \\
3149-3138(<0.01) \\
3096-2458(0.11)\end{array}$ \\
\hline
\end{tabular}


Appendix 2 (Continued)

\begin{tabular}{|c|c|c|c|}
\hline \multicolumn{2}{|l|}{ Lab nr } & $1-\sigma$ calib. range $\mathrm{BP}$ & $2-\sigma$ calib. range $\mathrm{BP}$ \\
\hline \multicolumn{4}{|c|}{ Early Copper Age } \\
\hline \multicolumn{4}{|c|}{ Tiszapolgár culture, Tiszapolgár-Basatanya cemetery (Early phase, bone samples) } \\
\hline Deb-348 & Grave 23 & $\begin{array}{l}4037-4021(0.03) \\
3995-3638(0.97)\end{array}$ & $\begin{array}{l}4241-3497(0.97) \\
3455-3377(0.03)\end{array}$ \\
\hline Deb-349 & Grave 28 & $\begin{array}{l}4038-4019(0.04) \\
3996-3657(0.96)\end{array}$ & $\begin{array}{l}4317-4297(0.01) \\
4262-3519(0.99)\end{array}$ \\
\hline Deb-342 & Grave 54 & $\begin{array}{l}4219-4213(0.01) \\
4149-4135(0.02) \\
4054-3655(0.97)\end{array}$ & $\begin{array}{l}4336-3518(0.999) \\
3392-3390(0.001)\end{array}$ \\
\hline Deb-361 & Grave 5 & $4358-3969(1.0)$ & $\begin{array}{l}4549-3757(0.99) ; \\
3753-3750(<0.01) \\
3744-3713(<0.01)\end{array}$ \\
\hline Deb-464 & Grave 61 & $\begin{array}{l}4458-4220(0.68) \\
4212-4150(0.14) \\
4134-4055(0.18)\end{array}$ & $4691-3951(1.0)$ \\
\hline Deb-416 & Grave 12 & $\begin{array}{l}4685-4320(0.94) \\
4294-4264(0.06)\end{array}$ & $\begin{array}{l}4840-4040(0.999) \\
4014-4001(0.001)\end{array}$ \\
\hline Summed probabilities & Tiszapolgár-Basatanya-Early & 4351-3710(1.0) & $\begin{array}{l}4704-3622(0.98) \\
3602-3523(0.02)\end{array}$ \\
\hline \multicolumn{4}{|c|}{ Tiszapolgár culture, Bélmegyer-Mondoki domb site } \\
\hline Bln-? & Bélmegyer-Mondoki domb & $\begin{array}{l}4233-4187(0.24) \\
4183-4045(0.76)\end{array}$ & $\begin{array}{l}4840-4040(0.996) \\
4014-4001(0.004)\end{array}$ \\
\hline \multicolumn{4}{|c|}{ Tiszapolgár culture, Méhkerék 23 site } \\
\hline Bln-2165 & Méhkerék 23 & $\begin{array}{l}4333-4227(0.69) \\
4202-4168(0.18) \\
4128-4118(0.04) \\
4097-4077(0.09)\end{array}$ & $4342-4050(1.0)$ \\
\hline \multicolumn{4}{|c|}{ Tiszapolgár culture, Vésztó-Mágor tell } \\
\hline Beta-162061 & Unit 6-1, bone sample & $\begin{array}{l}4345-4228(0.82) \\
4200-4170(0.14) \\
4126-4123(0.01) \\
4090-4081(0.04)\end{array}$ & $4364-4046(1.0)$ \\
\hline \multicolumn{4}{|c|}{ Tiszapolgár culture, Tiszapolgár? site } \\
\hline Deb-1936 & Tiszapolgár, no other information & $\begin{array}{l}4345-4317(0.44) \\
4297-4262(0.56)\end{array}$ & $4360-4236(1.0)$ \\
\hline \multicolumn{4}{|c|}{ Tiszapolgár culture, Hajdúböszörmény-Ficsori-tó-dülő cemetery } \\
\hline VERA-3789 & Grave 57/61, animal bone & $\begin{array}{l}4319-4294(0.17) \\
4264-4227(0.33) \\
4203-4167(0.29) \\
4128-4117(0.07) \\
4098-4076(0.14)\end{array}$ & $\begin{array}{l}4327-4283(0.17) \\
4271-4218(0.27) \\
4214-4148(0.28) \\
4135-4053(0.28)\end{array}$ \\
\hline VERA-3785 & Grave $30 / 34$, human bone & $\begin{array}{l}4325-4287(0.29) \\
4268-4228(0.36) \\
4201-4169(0.23) \\
4127-4120(0.04) \\
4094-4079(0.08)\end{array}$ & $\begin{array}{l}4331-4221(0.54) \\
4211-4150(0.23) \\
4134-4055(1.23)\end{array}$ \\
\hline VERA-3788 & Grave $30 / 34$, animal bone & $\begin{array}{l}4326-4285(0.28) \\
4269-4227(0.33) \\
4202-4168(0.23) \\
4128-4118(0.05) \\
4097-4077(0.11)\end{array}$ & $\begin{array}{l}4332-4218(0.52) \\
4214-4148(0.24) \\
4135-4054(0.24)\end{array}$ \\
\hline VERA-3787 & Grave $57 / 61$, human bone & $\begin{array}{l}4333-4312(0.33) \\
4302-4260(0.67)\end{array}$ & $\begin{array}{l}4347-4233(0.99) \\
4187-4183(0.01)\end{array}$ \\
\hline VERA-3786 & Grave $71 / 75$, human bone & $\begin{array}{l}4341-4318(0.41) \\
4296-4263(0.59)\end{array}$ & $4350-4242(1.0)$ \\
\hline Summed probabilities & Hajdúböszörmény-Ficsori & $\begin{array}{l}\text { 4336-4231(0.93); } \\
4190-4178(0.07)\end{array}$ & $\begin{array}{l}4346-4221(0.70) \\
4208-4152(0.15) \\
4131-4057(0.15)\end{array}$ \\
\hline
\end{tabular}


Appendix 2 (Continued)

Lab nr
Tiszapolgár culture, Körösladány-Bikeri site-upper level

Beta-234313 F48 well, sample 1

Beta-214596

F2 Outer circular ditch bottom fill

Beta-234312

F35 Bell-shaped pit fill

Beta-234306

F10 Bell-shaped pit fill

Beta-214595

F5 W1/2 Bell-shaped pit $(0-10 \mathrm{~cm})$

Beta-234314

F48 well, sample 2

Körösladány-Bikeri-upper level all 6 dates combined F28 Bell-shaped pit fill

Beta-234307

F29 trench in lower level

Beta-234308

Summed probabilities Körösladány-Bikeri-lower level

Tiszapolgár culture, Körösladány-Bikeri site-older dates Beta-234310 F30 fill (L1) in middle ditch

Beta-214597

F8,9 posthole in Inner ditch

Summed probabilities Körösladány-Bikeri-older dates

Summed probabilities, Körösladány-Bikeri site

all 10 dates combined

Tiszapolgár culture, Vésztô-Bikeri site-younger dates Beta-179782

F14 daub/cultural layer above floor $1-\sigma$ calib. range BP 2- $\sigma$ calib. range BP

4327-4282(0.27); 4334-4051(1.0) 4271-4226(0.29); 4204-4165(0.22); 4129-4114(0.08); 4100-4074(0.14) 4325-4287(0.29); $\quad 4331-4221(0.54)$; 4268-4228(0.36); $\quad 4211-4150(0.23)$; 4201-4169(0.23); 4134-4055(0.23) 4127-4120(0.04); 4094-4079(0.08)

4328-4280(0.41); 4274-4229(0.42); 4197-4172(0.17); $4087-4085(<0.01)$ 4347-4227(0.74); 4202-4168(0.15); 4128-4118(0.03); 4097-4077(0.08) 4332-4258(1.0)

4334-4223(0.65); 4208-4154(0.18); 4132-4059(0.17)

4444-4421(0.02); 4395-4386 $(<0.01)$; 4373-4042(0.98)

4351-4228(0.94); 4200-4170(0.05);

4090-4080(0.01)

$4339-4253(1.0)$

4364-4225(0.89);

4205-4162(0.07);

4130-4112(0.01);

4103-4071(0.03)

4336-4229 $(0.89) ; \quad 4349-4146(0.84)$;

4195-4173(0.11) $\quad$ 4134-4052(0.16)

4444-4421(0.28); $\quad 4453-4327(0.98)$;

4394-4386(0.07); 4282-4272(0.02)

4373-4335(0.65)

4447-4418(0.40); 4402-4357(0.60)

4445-4418(0.33); 4398-4380(0.19); 4373-4341(0.48)

$4461-4338(1.0)$

4459-4327(0.99); 4279-4273(0.01)

4325-4287(0.29); 4268-4228(0.36); 4201-4169(0.23); 4127-4120(0.04) 4094-4079(0.08) 4678-4658(0.12); 4701-4700(0.001); 4655-4637(0.13); 4694-4490(0.999) 4619-4536(0.75)

4675-4674 $(<0.01) ; \quad 4689-4486(0.99)$; 4668-4659 $(0.06) ; \quad 4475(<0.01)$; 4653-4637(0.11); $\quad 4468-4464(<0.01)$ 4617-4524(0.83) $4575(<0.01)$; 4683-4631(0.04); 4550-4548(<0.01); 4622-4499(0.13); 4446-4416(0.07); 4453-4218(0.66); 4401-4227(0.80); 4211-4148(0.09); 4200-4168(0.08); 4133-4053(0.08)

4126-4120(0.01); 4091-4078(0.03)

4231-4194(0.24); 4176-4144(0.20); 4138-4052(0.56)
4317-4296(0.03); 4263-4037(0.92); 4022-3994(0.05) 
Appendix 2 (Continued)

\begin{tabular}{|c|c|c|c|}
\hline Lab nr & & $1-\sigma$ calib. range BP & $2-\sigma$ calib. range $\mathrm{BP}$ \\
\hline Beta-162067 & F4 daub layer above floor level & $\begin{array}{l}4235-4146(0.51) \\
4136-4053(0.49)\end{array}$ & $\begin{array}{l}4325-4286(0.07) \\
4269-4036(0.88) \\
4023-3993(0.05)\end{array}$ \\
\hline Beta-214592 & F35 kiln/oven in well/cistern & $\begin{array}{l}4329-4251(0.99) \\
4246-4246(0.01)\end{array}$ & $\begin{array}{l}4347-4227(0.89) \\
4203-4167(0.07) \\
4128-4117(0.01) \\
4097-4076(0.02)\end{array}$ \\
\hline Beta-162071 & Block 4 midden base of plowzone & $\begin{array}{l}4336-4311(0.35) \\
4304-4259(0.65)\end{array}$ & $\begin{array}{l}4354-4231(0.98) \\
4194-4176(0.02)\end{array}$ \\
\hline Summed probabilities & Vésztô-Bikeri site-younger dates & $\begin{array}{l}4335-4227(0.84) \\
4199-4169(0.12) \\
4089-4079(0.04)\end{array}$ & $4340-4047(1.0)$ \\
\hline \multicolumn{4}{|c|}{ Tiszapolgár culture, Vésztó-Bikeri site-main occupation } \\
\hline Beta-179793 & F21 Middle circular ditch fill & $4335-4244(1.0)$ & $\begin{array}{l}4357-4224(0.84) \\
4206-4160(0.09) \\
4130-4070(0.07)\end{array}$ \\
\hline Beta-179792 & F20 Inner circular ditch fill EU6-6 & $4342-4259(1.0)$ & $\begin{array}{l}4439-4425(0.01) \\
4369-4226(0.92) \\
4203-4166(0.05) \\
4128-4116(0.01) \\
4098-4074(0.02)\end{array}$ \\
\hline Beta-179787 & F28 E w.t. F15, W. w.t. F4/14 & $\begin{array}{l}4446-4419(0.07) ; \\
4399-4381(0.05) ; \\
4374-4223(0.55) ; \\
4208-4155(0.15) ; \\
4132-4064(0.18)\end{array}$ & $4551-3963(1.0)$ \\
\hline Beta-179789 & F26 (in F4/14) N w.t.,posthole & $\begin{array}{l}4353-4313(0.52) \\
4301-4260(0.48)\end{array}$ & $\begin{array}{l}4447-4418(0.04) \\
4402-4231(0.95) \\
4193-4177(0.01)\end{array}$ \\
\hline Beta-214593 & F15 North wall trench fill & $\begin{array}{l}4366-4315(0.64) \\
4299-4261(0.36)\end{array}$ & $\begin{array}{l}4448-4415(0.09) \\
4405-4240(0.91)\end{array}$ \\
\hline Beta-162068 & F4 house floor level & $\begin{array}{l}4360-4323(0.70) \\
4289-4267(0.30)\end{array}$ & $\begin{array}{l}4446-4419(0.06) \\
4399-4382(0.02) \\
4374-4250(0.92)\end{array}$ \\
\hline Beta-162070 & F5 possible house base of $\mathrm{pz}$ & $\begin{array}{l}4441-4424(0.11) \\
4370-4321(0.65) \\
4293-4265(0.24)\end{array}$ & $4450-4255(1.0)$ \\
\hline Beta-179783 & F14 house floor level & $\begin{array}{l}4446-4419(0.28) \\
4399-4381(0.17) \\
4374-4334(0.55)\end{array}$ & $\begin{array}{l}4459-4318(0.93) \\
4296-4263(0.07)\end{array}$ \\
\hline Beta-179788 & F26 (in F4/14) north wall trench & $\begin{array}{l}4446-4420(0.36) \\
4398-4382(0.20) \\
4374-4345(0.44)\end{array}$ & $4455-4335(1.0)$ \\
\hline Beta-179786 & F28 E w.t. F15, W. w.t. F4/14 & $\begin{array}{l}4448-4415(0.35) \\
4405-4342(0.65)\end{array}$ & $\begin{array}{l}4499-4318(0.95) \\
4296-4263(0.05)\end{array}$ \\
\hline Beta-179790 & F19 Outer circular ditch fill & $\begin{array}{l}4446-4419(0.39) \\
4400-4379(0.27) \\
4375-4351(0.35)\end{array}$ & $4457-4338(1.0)$ \\
\hline Beta-179785 & F13 Bell pit (yellow clay zone) & $\begin{array}{l}4448-4415(0.40) \\
4405-4355(0.60)\end{array}$ & $4491-4334(1.0)$ \\
\hline Beta-179784 & F13 Bell-shaped pit (zone G) & $4452-4364(1.0)$ & $\begin{array}{l}4512-4511(0.001) \\
4503-4338(0.999)\end{array}$ \\
\hline Beta-214589 & F71 burial near r. tibia (charcoal) & $\begin{array}{l}4487-4476(0.09) \\
4464-4438(0.30) \\
4426-4369(0.61)\end{array}$ & $4519-4356(1.0)$ \\
\hline Beta-179791 & F27 posthole in Inner circular ditch & $\begin{array}{l}4493-4444(0.55) \\
4422-4372(0.45)\end{array}$ & $4530-4361(1.0)$ \\
\hline Summed probabilities & Vésztô-Bikeri-main occupation & $\begin{array}{l}\text { 4448-4325(0.93); } \\
4283-4269(0.07)\end{array}$ & $\begin{array}{l}4528-4229(0.99) \\
4195-4173(0.01)\end{array}$ \\
\hline
\end{tabular}


Appendix 2 (Continued)

\begin{tabular}{|c|c|}
\hline Lab nr & \\
\hline Tiszapolgár culture, Vés & tó-Bikeri site-older dates \\
\hline Beta-162066 & F4 house floor level EU2-18 \\
\hline Beta-162065 & F2 circular pit fill EU1-13 \\
\hline Beta-162069 & F4 house floor level EU2-37 \\
\hline Summed probabilities & Vésztô-Bikeri site-older dates \\
\hline Summed probabilities, & Vésztő-Bikeri site all dates \\
\hline Summed probabilities & iszapolgár culture \\
\hline
\end{tabular}

all 47 dates combined

Late Neolithic/Proto-Tiszapolgár phase, Deszk-Vénó site

Deb-1201 Pit 3, Square II

Late Neolithic/Proto-Tiszapolgár phase, Berettyóúffalu-Herpály tell

\begin{tabular}{|c|c|}
\hline Bln-2583 & Levels 6-5 \\
\hline Bln-2493 & Level 5 \\
\hline Bln-2668 & Levels 6-5 \\
\hline $\begin{array}{l}\text { Summed probabilities } \\
\text { Summed probabilities, I }\end{array}$ & $\begin{array}{l}\text { Berettyóújfalu-Herpály PTP } \\
\text { Proto-Tiszapolgár phase }\end{array}$ \\
\hline
\end{tabular}

Late Neolithic Csốszhalom culture, Bodrogzsadány-Akasztószer site

Deb-417 Sq.Ix, pit a, above ashy layer

Late Neolithic Csôszhalom culture, Tiszapolgár-Basatanya cemetery

Deb-357

Grave 84, bone sample

Late Neolithic Csốszhalom culture, Polgár-Csốszhalom tell

$\begin{array}{llll}\text { Bln-509 } & \text { H. I/A uppermost level, 0.3-0.4 m bs } & 4518-4335(1.0) & 4683-4632(0.03) ; \\ \text { Bln-512 } & & 4622-4237(0.97) \\ & \text { H. I/F 16a (3.05 m bs) lowest level } & 4724-4500(1.0) & 4844-4443(0.97) ; \\ & & 4423-4372(0.03) \\ \text { GrN-1993 } & & 4788-4667(0.84) ; & 4839-4547(1.0) \\ & \text { H. I/F, lowest level (charred grain) } & 4663-4653(0.04) ; & \\ \text { Bln-510 } & & 4639-4618(0.12) & \\ & \text { layer in Sec. I/10 (1.85 m bs) } & 4873-4871(0.01) ; & 4985-4500(1.0)\end{array}$

$1-\sigma$ calib. range BP 2- $\sigma$ calib. range $B P$

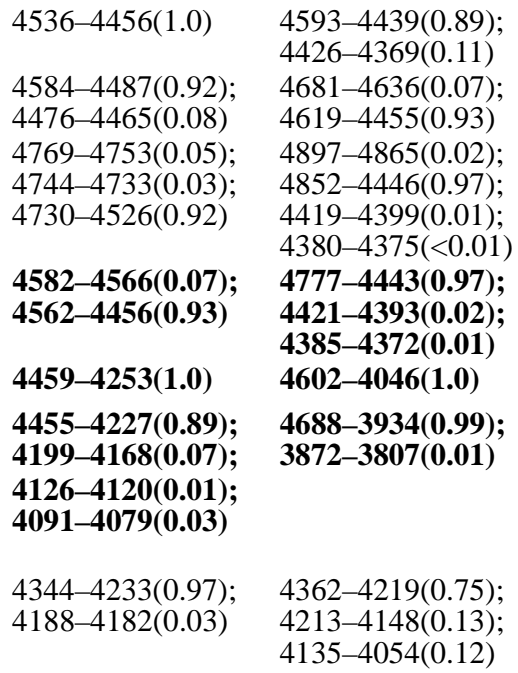

5207-5161(0.07); 5137-5129(0.01); 5120-5095(0.04); 5080-4679(0.85); $4657-4655(<0.01)$ 4637-4619(0.03)

5338-5334(0.001); 5329-4447(0.995); 4417-4403(0.004) 
Appendix 2 (Continued)

\begin{tabular}{|c|c|}
\hline \multicolumn{2}{|l|}{ Lab nr } \\
\hline Bln-513 & H. I/F (lowest level, 3.1-3.3 m bs \\
\hline BM-2321 & Layer $0.80-1.10 \mathrm{~m}$ deep \\
\hline \multicolumn{2}{|c|}{ Summed probabilities, Polgár-Csốszhalom tell } \\
\hline \multicolumn{2}{|c|}{ Summed probabilities, Csôszhalom culture $(n=8)$} \\
\hline Late Neol & ılture, Berettyóújfalu-Szilhalc \\
\hline Bln-2675 & Berettyóújfalu-Szilhalom \\
\hline
\end{tabular}

Late Neolithic Herpály culture, Esztár-Fenyvespart site

Bln-1679 Esztár-Fenyvespart

Late Neolithic Herpály culture, Berettyóúffalu-Herpály tell

$\begin{array}{ll}\text { Bln-2958 } & \text { Level } 6 \\ \text { Bln-2494 } & \text { Level } 6 \\ \text { Bln-2923 } & \text { Level } 6\end{array}$

$\begin{array}{ll}\text { Bln-2584 } & \text { Level } 6 \\ \text { Bln-2670 } & \text { Level } 6 \\ \text { Summed probabilities } & \text { Berettyóújfalu-Herpály Level } 6\end{array}$

Bln-2931 Level 7

$\begin{array}{ll}\text { Bln-2993 } & \text { Level 7 } \\ \text { Bln-2706 } & \text { Level 7 } \\ & \text { Level 7 } \\ \text { Bln-2937 } & \text { Level 7 } \\ \text { Bln-2924 } & \text { Berettyóúj } \\ \text { Summed probabilities } & \\ & \text { Levels 8-7 } \\ \text { Bln-2938 } & \text { Levels 8-7 }\end{array}$

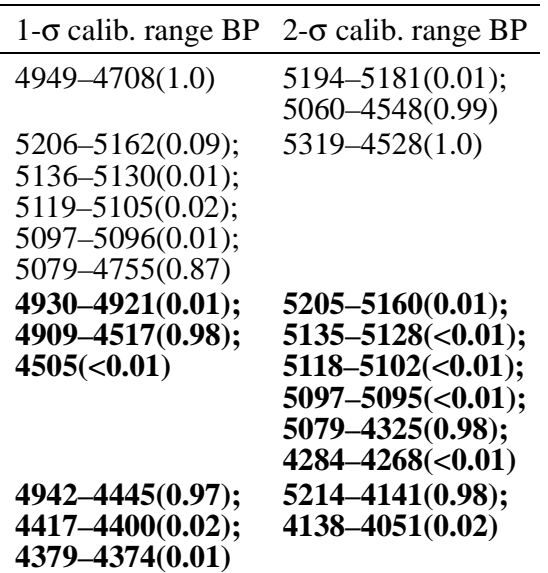


Appendix 2 (Continued)

\begin{tabular}{|c|c|c|c|}
\hline Lab nr & & $1-\sigma$ calib. range BP & $2-\sigma$ calib. range $\mathrm{BP}$ \\
\hline Bln-2929 & Levels 8-7 & $4720-4554(1.0)$ & $\begin{array}{l}4826-4816(0.007) \\
4801-4490(0.993)\end{array}$ \\
\hline Bln-2925 & Levels 8-7 & $4782-4606(1.0)$ & $\begin{array}{l}4844-4515(0.997) \\
4510-4504(0.003)\end{array}$ \\
\hline Summed probabilities & Berettyóújfalu-Herpály Levels 8-7 & $\begin{array}{l}4769-4753(0.05) \\
4745-4733(0.03) \\
4730-4520(0.83) \\
4484-4479(0.01) \\
4463-4447(0.04) \\
4417-4403(0.04)\end{array}$ & $4796-4352(1.0)$ \\
\hline $\mathrm{B} \ln -2673$ & Level 8 & $\begin{array}{l}4528-4438(0.63) \\
4426-4369(0.37)\end{array}$ & $\begin{array}{l}4652-4640(0.01) \\
4617-4340(0.99)\end{array}$ \\
\hline Bln-2939 & Level 8 & $4597-4452(1.0)$ & $\begin{array}{l}4685-4628(0.10) \\
4625-4438(0.80) \\
4426-4369(.10)\end{array}$ \\
\hline Bln-2927 & Level 8 & $\begin{array}{l}4677-4675(0.01) \\
4669-4659(0.05) \\
4655-4638(0.08) \\
4618-4460(0.86)\end{array}$ & $4719-4368(1.0)$ \\
\hline Bln-2930 & Level 8 & $\begin{array}{l}4647-4645(0.01) \\
4614-4463(0.99)\end{array}$ & $\begin{array}{l}4710-4447(0.98) \\
4418-4402(0.02) \\
4376(<0.01)\end{array}$ \\
\hline Bln-2932 & Level 8 & $\begin{array}{l}4682-4635(0.25) \\
4620-4499(0.75)\end{array}$ & $\begin{array}{l}4674-4758(<0.01) \\
4727-4445(0.97) ; \\
4420-4397(0.02) ; \\
4383-4374(0.01)\end{array}$ \\
\hline Bln-2933 & Level 8 & $\begin{array}{l}4776-4773(0.01) \\
4771-4751(0.11) \\
4749-4612(0.88)\end{array}$ & $\begin{array}{l}4832-4813(0.02) \\
4808-4541(0.98)\end{array}$ \\
\hline Bln-2940 & Level 8 & $\begin{array}{l}4785-4653(0.87) \\
4640-4617(0.13)\end{array}$ & $4836-4546(1.0)$ \\
\hline Bln-2928 & Level 8 & $4788-4612(1.0)$ & $\begin{array}{l}4892-4890(<0.01) \\
4882-4869(0.01) \\
4849-4522(0.99)\end{array}$ \\
\hline Summed probabilities & Berettyóújfalu-Herpály Level 8 & $4702-4462(1.0)$ & $\begin{array}{l}4822-4820(<0.01) \\
4799-4365(0.999)\end{array}$ \\
\hline Bln-2934 & Level 9 & $\begin{array}{l}4685-4629(0.28) \\
4625-4495(0.72)\end{array}$ & $\begin{array}{l}4769-4753(0.01) \\
4744-4734(0.01) \\
4729-4442(0.94) \\
4424-4371(0.04)\end{array}$ \\
\hline Bln-2935 & Level 9 & $\begin{array}{l}4710-4581(0.91) \\
4571-4555(0.09)\end{array}$ & $4782-4502(1.0)$ \\
\hline Bln-2936 & Level 9 & $\begin{array}{l}4893-4889(0.02) \\
4883-4869(0.08) \\
4849-4724(0.90)\end{array}$ & $\begin{array}{l}4982-4970(0.01) \\
4964-4687(0.99)\end{array}$ \\
\hline \multicolumn{2}{|c|}{ Summed probabilities, Berettyóújfalu-Herpály Level 9} & $\begin{array}{l}\text { 4825-4817(0.02); } \\
4820-4541(0.98)\end{array}$ & 4933-4451(1.0) \\
\hline \multicolumn{2}{|c|}{ Summed probabilities, Berettyóújfalu-Herpály tell } & $\begin{array}{l}4720-4448(0.995) \\
4411-4407(0.005)\end{array}$ & $\begin{array}{l}4831-4812(0.01) \\
4807-4324(0.98) \\
4285-4268(0.01)\end{array}$ \\
\hline Summed probabilities, & Berettyóújfalu-Herpály w/out PTP & 4721-4452(1.0) & $4835-4330(1.0)$ \\
\hline Summed probabilities, & Herpály culture $(n=27)$ & $4717-4455(1.0)$ & $\begin{array}{l}\text { 4832-4811(0.01); } \\
4808-4331(0.99)\end{array}$ \\
\hline \multicolumn{4}{|c|}{ Late Neolithic Tisza culture, Deszk-Ordos site } \\
\hline Bln-1934 & Deszk-Ordos & $4529-4344(1.0)$ & $\begin{array}{l}4686-4310(0.96) \\
4304-4259(0.04)\end{array}$ \\
\hline \multicolumn{4}{|c|}{ Late Neolithic Tisza culture, Kisköre-Gát site } \\
\hline Bln-515 & fireplace in pit (XVII,6) $1.6 \mathrm{~m}$ & $\begin{array}{l}4930-4924(0.02) \\
4910-4610(0.98)\end{array}$ & $5052-4462(1.0)$ \\
\hline
\end{tabular}


Appendix 2 (Continued)

\begin{tabular}{|c|c|c|c|}
\hline \multicolumn{2}{|l|}{ Lab nr } & \multirow{2}{*}{$\frac{1-\sigma \text { calib. range BP }}{4989-4792(1.0)}$} & \multirow{2}{*}{$\begin{array}{l}2-\sigma \text { calib. range BP } \\
5205-5168(0.02) ; \\
5075-4693(0.98)\end{array}$} \\
\hline Bln-179 & sherds $0.8-1.6 \mathrm{~m}$ bs (XVII,6) & & \\
\hline Summed p & sköre-Gát site & 4988-4718(1.0) & $\begin{array}{l}5201-5174(0.01) \\
5070-4513(0.99) \\
4506-4503(<0.01)\end{array}$ \\
\hline \multicolumn{4}{|c|}{ Late Neolithic Tisza culture, Hódmezôvásárhely-Gorzsa tell } \\
\hline Deb-1389 & Square IX, Level 2 & $4453-4356(1.0)$ & $4531-4331(1.0)$ \\
\hline $\mathrm{B} \ln ?$ & $?$ & $4520-4337(1.0)$ & $\begin{array}{l}4683-4633(0.03) \\
4622-4241(0.97)\end{array}$ \\
\hline Z-2009 & $\mathrm{C}$ & $4552-4339(1.0)$ & $4711-4254(1.0)$ \\
\hline Bln-3109 & $\mathrm{C}$ & $\begin{array}{l}4539-4444(0.75) \\
4421-4394(0.17) \\
4386-4373(0.08)\end{array}$ & $4611-4349(1.0)$ \\
\hline Fra-76 & H.2 (burned), Blk III, L. 10, $2.0 \mathrm{~m}$ & $4593-4362(1.0)$ & $\begin{array}{l}4767-4755(<0.01) \\
4741-4739(<0.01) \\
4728-4323(0.98) ; \\
4290-4266(0.01)\end{array}$ \\
\hline Fra-77 & H.2 (burned), Blk.III, L.10, $2.1 \mathrm{~m}$ & $\begin{array}{l}4613-4441(0.80) \\
4424-4370(0.20)\end{array}$ & $4724-4336(1.0)$ \\
\hline Deb-1238 & Square XI, Level 10 & $4866-4540(1.0)$ & $4722-4459(1.0)$ \\
\hline Deb-1175 & Sq.VIII, Lev. 16-17b & $4687-4545(1.0)$ & $\begin{array}{l}4763-4759(0.004) ; \\
4727-4460(0.996)\end{array}$ \\
\hline Deb-1171 & Square VI, Level 10 & $4687-4545(1.0)$ & $\begin{array}{l}4763-4759(0.004) \\
4727-4460(0.996)\end{array}$ \\
\hline Deb-1384 & Sq.VIII, L.17c-e & $\begin{array}{l}4701(0.006) ; \\
4695-4552(0.994)\end{array}$ & $4778-4495(1.0)$ \\
\hline Deb-1413 & Grave 16 , Square $X$ & $\begin{array}{l}4710-4581(0.91) \\
4751-4555(0.09)\end{array}$ & $4782-4502(1.0)$ \\
\hline Z-2010 & $\mathrm{C} 1$ & $4796-4541(1.0)$ & $\begin{array}{l}4948-4448(0.99) \\
4416-4404(0.01)\end{array}$ \\
\hline Deb-1354 & Grave 16 , Square $\mathrm{X}$ & $\begin{array}{l}4776-4773(0.01) \\
4771-4751(0.11) \\
4749-4612(0.88)\end{array}$ & $\begin{array}{l}4832-4813(0.02) \\
4808-4541(0.98)\end{array}$ \\
\hline Deb-1386 & Sq.VIII, Lev. 16-17b & $\begin{array}{l}4785-4653(0.87) \\
4640-4617(0.13)\end{array}$ & $4836-4546(1.0)$ \\
\hline Deb-1172 & Sq.VIII, Lev. 12-13 & $\begin{array}{l}4792-4668(0.86) \\
4660-4654(0.03) \\
4638-4618(0.01)\end{array}$ & $4842-4548(1.0)$ \\
\hline Deb-1174 & Sq.VIII, L.17c-e & $\begin{array}{l}4824-4818(0.02) \\
4800-4678(0.88) \\
4672-4670(0.01) \\
4658-4655(0.01) \\
4637-4619(0.08)\end{array}$ & $\begin{array}{l}4877-4871(0.005) \\
4848-4549(0.995)\end{array}$ \\
\hline Deb-1173 & Sq.XI, L.10, Ditch 1 & $\begin{array}{l}4831-4813(0.10) \\
4808-4689(0.90)\end{array}$ & $\begin{array}{l}4928-4925(<0.01) \\
4909-4862(0.05) \\
4858-4584(0.95)\end{array}$ \\
\hline Z-2011 & $\mathrm{D}$ & $\begin{array}{l}4906-4863(0.12) \\
4856-4648(0.79) \\
4644-4615(0.09)\end{array}$ & $5034-4494(1.0)$ \\
\hline Deb-1387 & Sq.XI, L.10, Ditch 1 & $4841-4709(1.0)$ & $\begin{array}{l}4936-4650(0.97) \\
4643-4615(0.03)\end{array}$ \\
\hline Deb-1240 & Grave 42, Sq. IX & $4841-4709(1.0)$ & $\begin{array}{l}4936-4650(0.97) \\
4643-4615(0.03)\end{array}$ \\
\hline Fra-114 & $\mathrm{C} 1$ & 4935-4686(1.0) & $5039-4539(1.0)$ \\
\hline Deb-1191 & Sq. XVIII, L.24-25 & $4846-4712(1.0)$ & $\begin{array}{l}4944-4667(0.97) \\
4663-4654(0.01) \\
4639-4617(0.02)\end{array}$ \\
\hline
\end{tabular}


Appendix 2 (Continued)

\begin{tabular}{|c|c|c|c|}
\hline \multicolumn{2}{|l|}{ Lab nr } & \multirow{2}{*}{$\begin{array}{l}1-\sigma \text { calib. range BP } \\
4981-4971(0.03) ; \\
4963-4727(0.97)\end{array}$} & \multirow{2}{*}{$\begin{array}{l}2-\sigma \text { calib. range BP } \\
5207-5159(0.03) ; \\
5152-5151(<0.01) ; \\
5136-5129(<0.01) ; \\
5120-5095(0.01) ; \\
5080-4606(0.96)\end{array}$} \\
\hline & Pits 2 and 3, Level 16 (earliest level) & & \\
\hline Fra-95 & Block III/b, L. 1, $1.15 \mathrm{~m}$ with 3 pots & $\begin{array}{l}\text { 4981-4971(0.03); } \\
4963-4727(0.97)\end{array}$ & $\begin{array}{l}5207-5159(0.03) ; \\
5152-5151(<0.01) \\
5136-5129(<0.01) \\
5120-5095(.01) ; \\
5080-4206(0.96)\end{array}$ \\
\hline Deb-1187 & Grave 42 , Sq. IX & $4945-4797(1.0)$ & $5020-4725(1.0)$ \\
\hline Deb-1202 & Grave 42 , Sq. IX & $\begin{array}{l}5029-4882(0.89) \\
4870-4849(0.11)\end{array}$ & $\begin{array}{l}5207-5159(0.05) ; \\
5136-5129(<0.01) \\
5119-5103(0.01) ; \\
5097-5096(<0.01) \\
5080-4792(0.93)\end{array}$ \\
\hline \multirow{2}{*}{\multicolumn{2}{|c|}{$\begin{array}{l}\text { Summed probabilities, Hódmezôvásárhely-Gorzsa } \\
\text { Summed probabilities, Tisza culture }(n=49)\end{array}$}} & 4846-4495(1.0) & 4994-4344(1.0) \\
\hline & & $\begin{array}{l}\text { 4893-4887(0.01); } \\
4883-4867(0.03) \\
4849-4497(0.96)\end{array}$ & $5003-4339(1.0)$ \\
\hline \multicolumn{4}{|c|}{ Late Neolithic Early Tisza culture, Hódmezóvásárhely-Kökénydomb tell } \\
\hline Deb-1222 & House 1, Level 3 & $\begin{array}{l}4719-4582(0.94) \\
4568-4557(0.06)\end{array}$ & $\begin{array}{l}4790-4514(0.99) \\
4510-4504(0.01)\end{array}$ \\
\hline Deb-1411 & House 1, Level 3 & $\begin{array}{l}4792-4668(086) \\
4660-4654(0.03) \\
4638-4618(0.10)\end{array}$ & $4842-4548(1.0)$ \\
\hline Deb-1255 & House 1, Level 3 & $4837-4703(1.0)$ & $\begin{array}{l}4932-4919(0.01) \\
4913-4607(0.99)\end{array}$ \\
\hline Deb-1364 & Levels $3-4$ & $\begin{array}{l}4830-4814(0.07) \\
4806-4685(0.91) \\
4629-4625(0.02)\end{array}$ & $\begin{array}{l}4896-4866(0.03) \\
4851-4580(0.96) \\
4572-4555(0.01)\end{array}$ \\
\hline Deb-1513 & Levels $3-5$ & $4841-4709(1.0)$ & $\begin{array}{l}4936-4650(0.97) \\
4643-4615(0.03)\end{array}$ \\
\hline Deb-1367 & Pit 2 & $4936-4789(1.0)$ & $4998-4719(1.0)$ \\
\hline Deb-1388 & House 1, Level 3 & $\begin{array}{l}5203-5172(0.12) \\
5072-4930(0.82) \\
4924-4909(0.05) \\
4862-4859(0.01)\end{array}$ & $\begin{array}{l}5209-4879(0.96) \\
4871-4848(.04)\end{array}$ \\
\hline Deb-1412 & Level 6 & $\begin{array}{l}5206-5166(0.18) \\
5117-5109(0.03) \\
5078-4935(0.79)\end{array}$ & $\begin{array}{l}5213-4893(0.97) \\
4889-4883(<0.01) \\
4869-4849(0.03)\end{array}$ \\
\hline Deb-1365 & Pit 1 & $5208-5034(1.0)$ & $\begin{array}{l}5292-5251(0.03) \\
5228-4938(0.97)\end{array}$ \\
\hline Deb-1263 & House 1, Level 3 & $5218-5054(1.0)$ & $5302-4998(1.0)$ \\
\hline \multicolumn{2}{|c|}{ Summed probabilities, Hódmezốvásárhely-Kökénydomb } & $\begin{array}{l}5205-5163(0.08) \\
5131-5130(0.01) \\
5118-5106(0.02) \\
5078-4980(0.20) ; \\
4968-4963(0.01) ; \\
4894-4866(0.05) ; \\
4849-4667(0.58) ; \\
4659-4653(0.01) ; \\
4637-4617(0.04)\end{array}$ & $\begin{array}{l}5215-4580(0.99) \\
4570-4554(0.01)\end{array}$ \\
\hline \multicolumn{4}{|c|}{ Late Neolithic Early Tisza culture, Szegvár-Tüzköves tell } \\
\hline Deb-1221 & Pit 93, Level 20 & $\begin{array}{l}4719-4582(0.94) \\
4568-4557(0.06)\end{array}$ & $\begin{array}{l}4790-4514(0.995) \\
4510-4504(0.005)\end{array}$ \\
\hline Deb-1355 & Grave 1, Levels 10-12 & $\begin{array}{l}4776-4773(0.01) \\
4771-4751(0.11) \\
4749-4612(0.88)\end{array}$ & $\begin{array}{l}\text { 4832-4813(0.02); } \\
4808-4541(0.98)\end{array}$ \\
\hline
\end{tabular}


Appendix 2 (Continued)

\begin{tabular}{|c|c|}
\hline Lab nr & \\
\hline Deb-1256 & Levels 19-20 \\
\hline Deb-1229 & Levels 26-27 \\
\hline Deb-1420 & Pit 105, Level 29 \\
\hline BM-2323 & Pit in Tisza Layer o \\
\hline Deb-1254 & Levels 23-24 \\
\hline BM-2322 & Pit in Tisza Layer ov \\
\hline \multicolumn{2}{|c|}{ Summed probabilities, Szegvár-Túzköves te } \\
\hline \multicolumn{2}{|c|}{$\begin{array}{l}\text { Late Neolithic Early Tisza, Vésztó-Mágor tell } \\
\text { Bln-1342 }\end{array}$} \\
\hline Bln-1626 & House in Level 4 \\
\hline Bln-1625 & House in Level 3 \\
\hline Bln-1628 & House in Level 3 \\
\hline
\end{tabular}

\section{Summed probabilities, Vésztő-Mágor E. Tisza}

Late Neolithic Early Tisza culture, Tápé-Lebö-A tell Deb-1186 Levels 1-2

Z-2007

Deb-1211 Level 8

Deb-1356 Ditch 14, Level 16

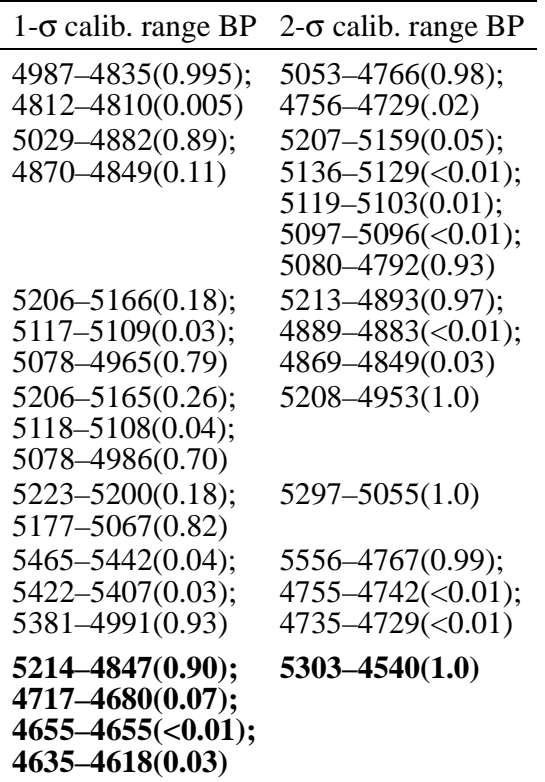

4950-4768(0.94); 4754-4743(0.04); 4734-4729(0.02) 4976(0.01); 4961-4826(0.91); 4816-4800(0.08)

$5208-5034(1.0)$

5197-5179(0.01);

5063-4683(0.99); $4633-4622(<0.01)$ 5038-4764(0.97); 4758-4728(0.03)

5292-5251(0.03); 5228-4938(0.97)

5310-5207(0.76); $5352-5351(0.001)$; 5161-5137(0.11); 5345-5046(0.999)

5129-5120(0.05); 5102-5100(0.01); 5095-5080(0.07)

5283-5273(0.02); 5223-5191(0.08); 5182-5056 (0.32); 4992-4795(0.58)

5308-4765(0.98); 4755-4727(0.02)

4824-4818(0.02); 4800-4678(0.88); 4672-4670(0.01); 4658-4655(0.01); 4637-4619(0.08) 4892-4889(0.01); 4883-4869(0.03); 4849-4589(0.96) 4841-4709(1.0)

4927-4925(0.01); 4909-4862(0.28); 4858-4768(0.63); 4754-4743(0.05) 4734-4729(0.03)
$4486(0.99)$ 4478-4464(0.01)

4936-4650(0.97); 4643-4615(0.03)

4877-4871(0.005); 4848-4549(0.995)

4988-4709(1.0) 
Appendix 2 (Continued)

\begin{tabular}{|c|c|c|c|}
\hline \multicolumn{2}{|l|}{ Lab nr } & \multirow{2}{*}{$\begin{array}{l}1-\sigma \text { calib. range BP } \\
5029-4882(0.89) ; \\
4870-4849(0.11)\end{array}$} & \multirow{2}{*}{$\begin{array}{l}2-\sigma \text { calib. range BP } \\
5207-5159(0.05) ; \\
5136-5129(<0.01) ; \\
5119-5103(0.01) ; \\
5097-5096(<0.01) ; \\
5080-4792(0.93)\end{array}$} \\
\hline Deb-1363 & Ditch 14, Level 16 & & \\
\hline Deb-1176 & Levels 5-6 & $\begin{array}{l}5029-4882(0.89) \\
4870-4849(0.11)\end{array}$ & $\begin{array}{l}5207-5159(0.05) ; \\
5136-5129(<0.01) \\
5119-5103(0.01) ; \\
5097-5096(<0.01) \\
5080-4792(0.93)\end{array}$ \\
\hline Deb-1264 & Levels $12-13$ & $\begin{array}{l}5206-5166(0.18) \\
5117-5109(0.03) \\
5078-4935(0.79)\end{array}$ & $\begin{array}{l}5213-4893(0.97) \\
4889-4883(<0.01) \\
4869-4849(0.03)\end{array}$ \\
\hline Deb-1196 & Pit 24, Level 6 & $\begin{array}{l}5207-5145(0.33) \\
5138-5127(0.05) \\
5121-5093(0.13) \\
5081-4996(0.49)\end{array}$ & $\begin{array}{l}5223-4900(0.99) \\
4864-4854(0.01)\end{array}$ \\
\hline Deb-1267 & Pit 41, Level 14 & $5208-5034(1.0)$ & $\begin{array}{l}5292-5251(0.03) \\
5228-4938(0.97)\end{array}$ \\
\hline Deb-1188 & Level 10 & $5208-5034(1.0)$ & $\begin{array}{l}5292-5251(0.03) \\
5228-4938(0.97)\end{array}$ \\
\hline Deb-1265 & Pit 37, Level 12 & $5213-5049(1.0)$ & $\begin{array}{l}5297-4980(0.99) \\
4971-4963(0.01)\end{array}$ \\
\hline Deb-1200 & Pit 35, Level 12 & $5213-5049(1.0)$ & $\begin{array}{l}5297-4980(0.99) \\
4971-4963(0.01)\end{array}$ \\
\hline Deb-1197 & Pit 32, Level 12 & $5223-5054(1.0)$ & $5303-5005(1.0)$ \\
\hline Deb-1195 & Levels $14-15$ & $\begin{array}{l}5291-5268(0.11) \\
5226-5195(0.18) \\
5180-5061(0.71)\end{array}$ & $5308-5016(1.0)$ \\
\hline Deb-1189 & Levels $12-14$ & $\begin{array}{l}5298-5206(0.57) \\
5165-5118(0.26) \\
5108-5078(0.17)\end{array}$ & $5320-5027(1.0)$ \\
\hline Deb-1366 & Pit 53, Level 16 & $\begin{array}{l}5338-5334(0.02) \\
5329-5212(0.98)\end{array}$ & $\begin{array}{l}5464-5445(0.01) \\
5420-5409(0.01) \\
5380-5197(0.83) \\
5179-5063(0.15)\end{array}$ \\
\hline Deb-1643 & Fea. 39, Level 17(12) charcoal & $\begin{array}{l}5466-5437(0.20) \\
5425-5405(0.13) \\
5384-5305(0.67)\end{array}$ & $\begin{array}{l}5473-5286(0.90) \\
5272-5224(0.10)\end{array}$ \\
\hline Summed p & Гápé-Lebố-A tell & $\begin{array}{l}5300-4931(0.94) \\
4920-4911(0.01) \\
4793-4777(0.02) \\
4772-4769(0.01) \\
4750-4746(0.01) \\
4732-4729(0.01)\end{array}$ & $\begin{array}{l}5461-5449(<0.01) \\
5375-4652(0.99) \\
4638-4616(0.01)\end{array}$ \\
\hline Summed p & Carly Tisza culture $(n=39)$ & $\begin{array}{l}5216-4906(0.75) \\
4862-4856(0.01) \\
4834-4710(0.24)\end{array}$ & $\begin{array}{l}5320-4580(0.99) \\
4570-4554(0.01)\end{array}$ \\
\hline Summed p & ate Neolithic $(n=107)$ & $\begin{array}{l}5021-5000(0.02) \\
4949-4446(0.96) \\
4416-4402(0.02)\end{array}$ & $5297-4328(1.0)$ \\
\hline Summed p & ate Neolithic w/o PTP $(n=103)$ & $\begin{array}{l}5025-4999(0.03) \\
4949-4450(0.97)\end{array}$ & $\begin{array}{l}5293-5249(0.02) \\
5228-4339(0.98)\end{array}$ \\
\hline
\end{tabular}

